CrossMark \&lick for updates

Cite this: Dalton Trans., 2015, 44, 12196

Received 16th March 2015 Accepted 7th April 2015

DOI: 10.1039/c5dt01041a

www.rsc.org/dalton

\section{Catalytic catechol oxidation by copper complexes: development of a structure-activity relationship $\dagger$}

\author{
Erica C. M. Ording-Wenker, ${ }^{a}$ Maxime A. Siegler, ${ }^{b}$ Martin Lutz ${ }^{\mathrm{C}}$ and \\ Elisabeth Bouwman*a
}

\begin{abstract}
A large library of $\mathrm{Cu}^{\text {Il }}$ complexes with mononucleating and dinucleating ligands was synthesized to investigate their potential as catalysts for the catalytic oxidation of 3,5-di-tert-butylcatechol (3,5-DTBC). X-ray structure determination for a number of these complexes revealed relatively large $\mathrm{Cu}$... Cu distances and the formation of polymeric species. Comparison of the 3,5-DTBC oxidation rates showed that ligands that stabilize the biomimetic dinuclear $\mathrm{Cu}^{\prime \prime} \mu$-thiolate complex also result in copper compounds that are much more active in the oxidation of 3,5-DTBC. This oxidation activity is however inhibited by the presence of chloride ions. The highest $k_{\text {cat }}$ that was observed was $6900 \mathrm{~h}^{-1}$, which is one of the highest turnover frequencies reported so far for catechol oxidation in $\mathrm{CH}_{3} \mathrm{CN}$.
\end{abstract}

\section{Introduction}

The formation and redox properties of synthetic dinuclear $\mathrm{Cu}^{\mathrm{II}}$ $\mu$-thiolate complexes have been investigated because of their similarity to the $\mathrm{Cu}_{\mathrm{A}}$ site. ${ }^{1-6}$ It has been reported that small changes in the ligand structure can direct the reaction with copper salts towards the formation of either a $\mathrm{Cu}^{\mathrm{II}} \mu$-thiolate or a $\mathrm{Cu}^{\mathrm{I}}$ disulfide complex and that these species can interconvert (Fig. 1a). ${ }^{7,8}$ Similar changes in the ligand structure can also induce a difference in coordination mode of dioxygen to copper. ${ }^{9,10}$ Additionally, the redox conversion of a $\mathrm{Cu}_{2}^{\mathrm{II}}\left(\mu-\eta^{2}\right.$ : $\eta^{2}$-peroxide) or a $\mathrm{Cu}_{2}^{\mathrm{II}}\left(\mu-1,2\right.$-peroxide) complex into a $\mathrm{Cu}_{2}^{\mathrm{III}}(\mu \text {-oxide })_{2}$ species has been reported ${ }^{11-13}$ suggesting that copper-oxygen chemistry might be very similar to copper-sulfur chemistry. To investigate this hypothesis we undertook a study of the biomimetic catalytic oxidation of 3,5-di-tert-butylcatechol (3,5-DTBC) to 3,5-di-tert-butyl-o-benzoquinone (3,5-DTBQ) using $\mathrm{Cu}^{\mathrm{II}} \mathrm{com}^{-}$ plexes with mononucleating and dinucleating ligands containing sulfur donor atoms. The oxidation of catechol to quinone by catechol oxidase is assumed to proceed in two steps: the first molecule of catechol is oxidized by the binuclear $\mathrm{Cu}^{\mathrm{II}}$ site with the formation of $\mathrm{Cu}_{2}^{\mathrm{I}}$ and two protons. In the second step

\footnotetext{
${ }^{a}$ Leiden Institute of Chemistry, Gorlaeus Laboratories, Leiden University, P.O. Box 9502, 2300 RA Leiden, The Netherlands.E-mail: bouwman@chem.leidenuniv.nl ${ }^{b}$ Department of Chemistry, Johns Hopkins University, Baltimore, Maryland 21218, USA

${ }^{c}$ Bijvoet Center for Biomolecular Research, Utrecht University, Padualaan 8 , 3584 CH Utrecht, The Netherlands

$\dagger$ Electronic supplementary information (ESI) available. CCDC 1043165-1043173 and 1042477. For ESI and crystallographic data in CIF or other electronic format see DOI: $10.1039 / \mathrm{c} 5 \mathrm{dt} 01041 \mathrm{a}$
}

a

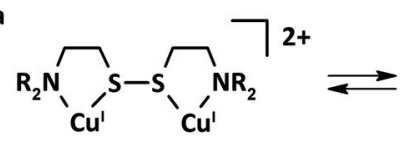

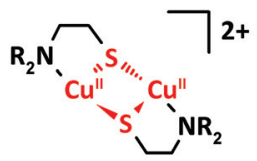

b<smiles>[R20]C1CCS(S2=[Ge]N([R16])CC2)=[GeH]1</smiles>

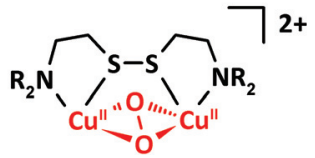

Fig. 1 Schematic representation of (a) the equilibrium between a $\mathrm{Cu}^{\prime}$ disulfide and $\mathrm{Cu}^{\prime \prime} \mu$-thiolate species and (b) the hypothesized reaction of a Cu' disulfide complex with $\mathrm{O}_{2}$ to form a side-on $\mathrm{Cu}_{2}^{\prime \prime}\left(\mu-\eta^{2}: \eta^{2}\right.$-peroxide) species.

the $\mathrm{Cu}_{2}^{\mathrm{I}}$ site reacts with $\mathrm{O}_{2}$ to form a $\mathrm{Cu}_{2}^{\mathrm{II}}\left(\mu-\eta^{2}: \eta^{2}\right.$-peroxide) species, which oxidizes a second molecule of catechol with the formation of two molecules of water. ${ }^{14-16}$ However, it has also been suggested that only one equivalent of catechol may be oxidized with the formation of dihydrogen peroxide, which would proceed via the $\mathrm{Cu}_{2}^{\mathrm{II}}\left(\mu-\eta^{2}: \eta^{2}\right.$-peroxide) species. ${ }^{17}$ This $\mathrm{Cu}_{2}^{\mathrm{II}}\left(\mu-\eta^{2}: \eta^{2}\right.$-peroxide) species shows quite some similarities to the $\mathrm{Cu}^{\mathrm{II}} \mu$-thiolate complex (Fig. 1). Nevertheless, the involvement of other types of copper-oxygen intermediates cannot be ruled out. ${ }^{18}$ The oxidation of 3,5-DTBC is easy to monitor and is used as a common test reaction for new biomimetic copper complexes. ${ }^{16}$ The structural and electronic similarity between the $\mathrm{Cu}^{\mathrm{II}} \mu$-thiolate and $\mathrm{Cu}_{2}^{\mathrm{II}}\left(\mu-\eta^{2}: \eta^{2}\right.$-peroxide) complex might lead to a more effective or more stabilizing reaction with $\mathrm{O}_{2}$ by complexes of ligands that promote $\mathrm{Cu}^{\mathrm{II}} \mu$-thiolate formation. However, it is clear that if a $\mathrm{Cu}^{\mathrm{II}} \mu$-thiolate species would form, it will be oxygenated by dioxygen. ${ }^{19}$ 

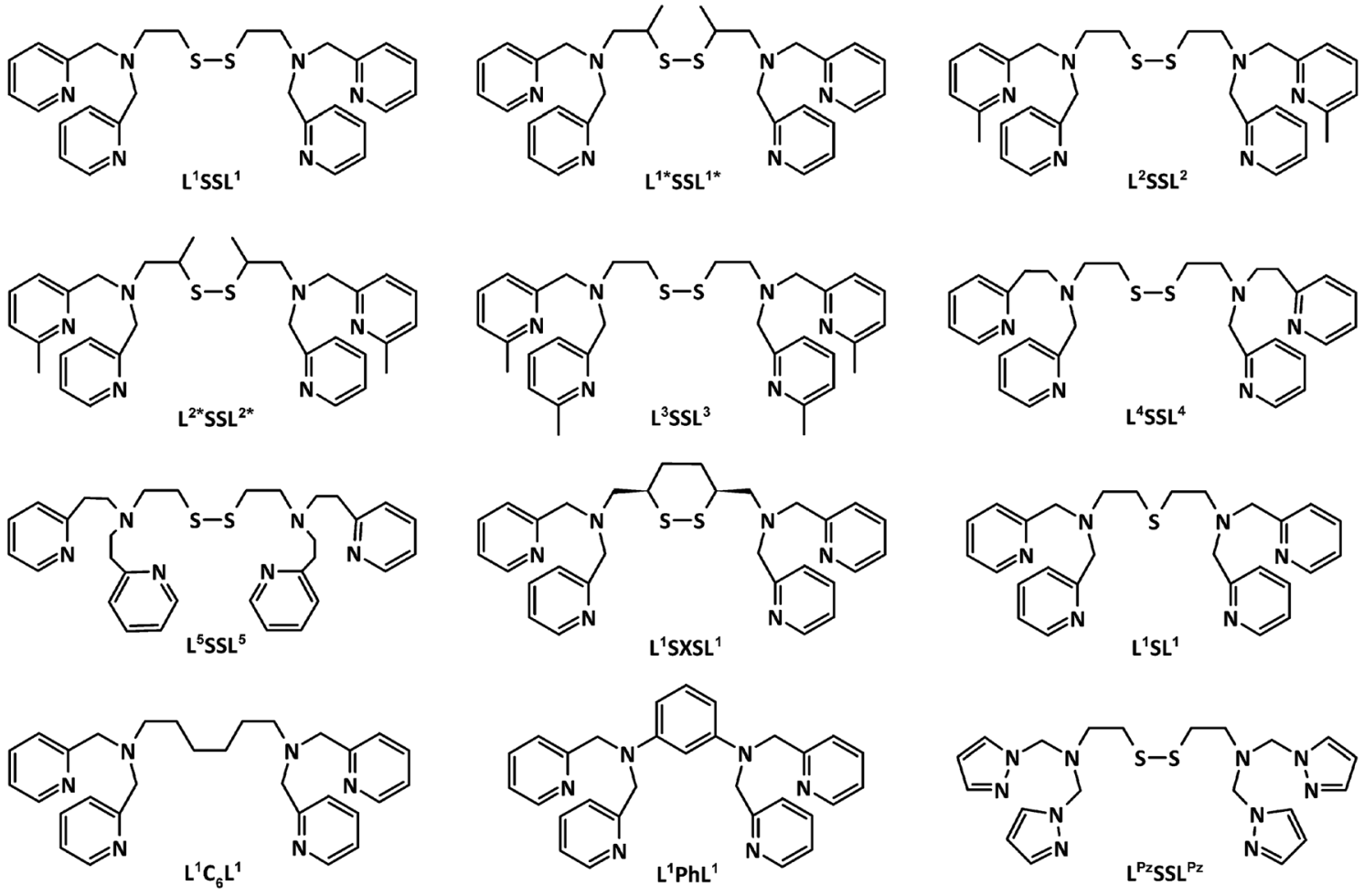<smiles>c1ccc(CN(Cc2ccccn2)c2cccc(N(Cc3ccccn3)Cc3ccccn3)c2)nc1</smiles><smiles>c1cnn(CCCN(CCSSCCN(Cn2cccn2)Cn2cccn2)Cn2cccn2)c1</smiles><smiles>Cc1cc(C)n(CN(CCSSCCN(Cn2nc(C)cc2C)Cn2nc(C)cc2-n2nc(C)cc2C)Cn2nc(C)cc2C)n1</smiles><smiles></smiles><smiles>CSCCN(Cc1ccccn1)Cc1ccccn1</smiles><smiles>CSC(C)CN(Cc1ccccn1)Cc1ccccn1</smiles><smiles>CSCCN(Cc1ccccn1)Cc1cccc(C)n1</smiles><smiles>CSCCN(Cc1cccc(C)n1)Cc1cccc(C)n1</smiles><smiles>OCCN(Cc1ccccn1)Cc1ccccn1</smiles><smiles>NCCN(Cc1ccccn1)Cc1ccccn1</smiles>

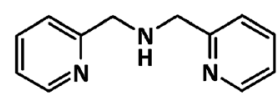

$\mathrm{Py}_{2} \mathrm{NH}$

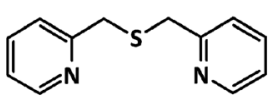

$\mathrm{Py}_{2} \mathrm{~S}$

Fig. 2 Schematic overview of the ligands that were synthesized for the study of the copper-catalyzed oxidation of catechol.

In this paper the synthesis of a series of $\mathrm{Cu}^{\mathrm{II}}$ complexes with mononucleating and dinucleating ligands is described. To have a complete picture of the effect of small ligand changes on the catechol oxidation activity, a large library of ligands was rationally selected for this study (Fig. 2). X-ray crystal structures were obtained for a number of copper complexes and some of these are discussed.

\section{Results}

\subsection{Ligand and complex synthesis}

Most of the ligands shown in Fig. 2 were synthesized according to literature procedures or are commercially available. ${ }^{4,7,8,20-24}$
As the ligands are similar to each other, they were systematically named by their structure. For example $\mathbf{L}^{\mathbf{1}}$ stands for the fragment $N, N$-bis(2-pyridylmethyl)aminoethyl and $\mathbf{P y}$ for 2-pyridylmethyl.

Ligand $\mathbf{L}^{\mathbf{1}} \mathbf{S C H}_{\mathbf{3}}$ was synthesized by reductive amination of 2-(methylthio)ethylamine, avoiding the use of toxic 2-chloroethyl methyl sulfide, ${ }^{25}$ and increasing the yield from $53 \%$ to 99\%. A similar synthesis was used for the formation of $\mathbf{L}^{1} \mathbf{O H}$ increasing the reported yield from $85 \%$ to $99 \% .{ }^{26}$ The ligand $\mathbf{P y}_{2} \mathbf{S}$ has been reported, but its synthesis has not been described elaborately. ${ }^{27}$ Four new ligands were designed: $\mathbf{L}^{\mathbf{1}} \mathbf{S L}^{\mathbf{1}}, \mathbf{L}^{\mathbf{1}}{ }^{*} \mathbf{S C H} \mathbf{H}_{3}$, $\mathbf{L}^{2} \mathbf{S C H}_{3}$ and $\mathbf{L}^{3} \mathbf{S C H}_{3}$. $\mathbf{L}^{\mathbf{1}} \mathbf{S L}^{\mathbf{1}}$ was synthesized by reductive amination of 1,5-diamino-3-thiapentane dihydrobromide, which 
was made via a 4-step literature procedure. ${ }^{28} \mathbf{L}^{1} \mathbf{S L}^{\mathbf{1}}$ was obtained in $68 \%$ yield as brown oil. $\mathbf{L}^{\mathbf{1}^{*}} \mathbf{S} \mathbf{C} \mathbf{H}_{3}$ was synthesized by reaction of propylene sulfide with di-(2-pyridylmethyl) amine in acetonitrile. After solvent evaporation, tetrahydrofuran and $\mathrm{NaH}$ were added to deprotonate the thiol. Addition of $\mathrm{CH}_{3}$ I yields $\mathbf{L}^{\mathbf{1}} \mathbf{S C H}_{3}$, which was purified by column chromatography, resulting in $86 \%$ yield. $\mathbf{L}^{2} \mathbf{S C H}_{3}$ and $\mathbf{L}^{3} \mathbf{S} \mathbf{C H}_{3}$ were obtained in relatively moderate yields of $50 \%$ and $46 \%$ by a two-step reductive amination using $\mathrm{NaBH}_{4}$. All synthesized ligands degrade over a period of weeks, even when stored under argon at $0{ }^{\circ} \mathrm{C}$, as indicated by darkening of the oil. When the ligands are coordinated to copper, the complexes are stable over time. A schematic overview of the syntheses of the new ligands is shown in the ESI. $\dagger$

With the 22 ligands, $\mathrm{Cu}^{\text {II }}$ complexes were formed with one $\mathrm{Cl}^{-}$and one $\mathrm{BF}_{4}{ }^{-}$counterion per copper center. The general synthesis of these complexes entails the addition of a $1: 1$ mixture of $\left[\mathrm{Cu}^{\mathrm{II}}\left(\mathrm{H}_{2} \mathrm{O}\right)_{6}\right]\left(\mathrm{BF}_{4}\right)_{2}$ and $\mathrm{Cu}^{\mathrm{II}} \mathrm{Cl}_{2} \cdot 2 \mathrm{H}_{2} \mathrm{O}$ to the ligand dissolved in methanol, or in the case of $\mathbf{L}^{2} \mathbf{S S L}^{2}$ and $\mathbf{L}^{\mathbf{1}} \mathbf{N H}_{2}$ in $\mathrm{CH}_{3} \mathrm{CN}$. If the complex did not precipitate spontaneously, precipitation was induced by addition of diethyl ether. Copper compounds of ligands that can potentially form dinuclear complexes are more likely to form polymeric structures (see Section 2.2), and are tentatively indicated with the formula $\left[\mathrm{Cu}_{2}^{\mathrm{II}} \text { (ligand) }(\mathrm{Cl})_{2}\right]_{n}\left(\mathrm{BF}_{2}\right)_{n}$. The complexes of ligands that are expected to form mononuclear compounds are indicated with the formula $\left[\mathrm{Cu}^{\mathrm{II}}\right.$ (ligand) $\left.(\mathrm{Cl})\right]\left(\mathrm{BF}_{4}\right)$. A copper complex with $\mathbf{L}^{5} \mathbf{S S L}^{5}$ could not be isolated as a solid; all attempts resulted in the formation of oil. For the catalytic experiments, this complex was formed in situ. In the synthesis of a complex with $\mathbf{L}^{2} \mathbf{S S L}^{2},\left[\mathrm{Cu}^{\mathrm{II}}\left(\mathrm{H}_{2} \mathrm{O}\right)_{6}\right]\left(\mathrm{ClO}_{4}\right)_{2}$ was used instead of $\left[\mathrm{Cu}^{\mathrm{II}}\left(\mathrm{H}_{2} \mathrm{O}\right)_{6}\right]\left(\mathrm{BF}_{4}\right)_{2}$ to grow single crystals suitable for X-ray structure determination. However, the complex $\left[\mathrm{Cu}_{2}^{\mathrm{II}}\left(\mathbf{L}^{2} \mathbf{S S L}^{2}\right)\right.$ $\left.(\mathrm{Cl})_{2}\right]_{n}\left(\mathrm{BF}_{4}\right)_{2 n}$ was also synthesized, so that all catalysts used for catechol oxidation have the same counterions. With the ligand $\mathbf{L}^{\mathbf{1}^{*}} \mathbf{S C H}_{\mathbf{3}}$ two complexes were formed: $\left[\mathrm{Cu}^{\mathrm{II}}\left(\mathbf{L}^{\mathbf{1}}{ }^{*} \mathbf{S C} \mathbf{H}_{\mathbf{3}}\right)\right.$ $(\mathrm{Cl})]_{2}\left(\mathrm{CuCl}_{4}\right)$ and $\left[\mathrm{Cu}^{\mathrm{II}}\left(\mathbf{L}^{\mathbf{1}} \mathbf{S C H}_{3}\right)(\mathrm{Cl})\right]\left(\mathrm{BF}_{4}\right)$. The first compound was obtained by addition of 1 equiv. of $\mathrm{Cu}^{\mathrm{II}} \mathrm{Cl}_{2} \cdot 2 \mathrm{H}_{2} \mathrm{O}$ to $\mathbf{L}^{\mathbf{1}^{*}} \mathbf{S C H}_{3}$, the latter from 0.5 equiv. of $\mathrm{Cu}^{\mathrm{II}} \mathrm{Cl}_{2} \cdot 2 \mathrm{H}_{2} \mathrm{O}$ and 0.5 equiv. of $\left[\mathrm{Cu}^{\mathrm{II}}\left(\mathrm{H}_{2} \mathrm{O}\right)_{6}\right]\left(\mathrm{BF}_{4}\right)_{2}$. The X-ray crystal structures were determined for both complexes and the structures of their cationic copper complex were found to be very similar. The ESI $\dagger$ contains the crystallographic information for both structures.

The UV-vis spectra of all the $\mathrm{Cu}^{\mathrm{II}}$ complexes are highly similar, showing LMCT bands of $\mathrm{Cu}^{\mathrm{II}} \leftarrow \mathrm{S}$ and $\mathrm{Cu}^{\mathrm{II}} \leftarrow \mathrm{Cl}$ in the region between 200 and $400 \mathrm{~nm}$ and one or two bands in the range of 650 to $940 \mathrm{~nm}$ that can be ascribed to $\mathrm{Cu}^{\mathrm{II}} \mathrm{d}-\mathrm{d}$ transitions (Fig. S7†).

\subsection{Description of X-ray crystal structures}

Single crystals could be obtained for several of the synthesized $\mathrm{Cu}^{\mathrm{II}}$ complexes. This led to the X-ray crystal structure determination of the polymeric complexes $\left[\mathrm{Cu}_{2}^{\mathrm{II}}\left(\mathbf{L}^{\mathbf{1}} \mathbf{S S L}^{\mathbf{1}}\right)(\mathrm{Cl})_{2}\right]_{n}\left(\mathrm{BF}_{4}\right)_{2 n}$, $\left[\mathrm{Cu}_{2}^{\mathrm{II}}\left(\mathbf{L}^{2} \mathbf{S S L}^{2}\right)(\mathrm{Cl})_{2}\right]_{n}\left(\mathrm{ClO}_{4}\right)_{2 n}, \quad\left[\mathrm{Cu}_{2}^{\mathrm{II}}\left(\mathbf{L}^{\mathbf{1}} \mathbf{S L}^{\mathbf{1}}\right)(\mathrm{Cl})_{2}\right]_{n}\left(\mathrm{BF}_{4}\right)_{2 n}$ and $\left[\mathrm{Cu}_{2}^{\mathrm{II}}\left(\mathbf{L}^{\mathbf{1}} \mathbf{C}_{6} \mathbf{L}^{\mathbf{1}}\right)(\mathrm{Cl})_{2}\right]_{n}\left(\mathrm{BF}_{4}\right)_{2 n}$ and of the compounds of mononucleating ligands, namely $\left[\mathrm{Cu}^{\mathrm{II}}\left(\mathbf{L}^{\mathbf{1}} \mathbf{S C H} \mathbf{C H}_{3}\right)(\mathrm{Cl})\right]\left(\mathrm{BF}_{4}\right)$,
$\left[\mathrm{Cu}^{\mathrm{II}}\left(\mathbf{L}^{\mathbf{1}^{*}} \mathbf{S C H}_{3}\right)(\mathrm{Cl})\right]\left(\mathrm{BF}_{4}\right),\left[\mathrm{Cu}^{\mathrm{II}}\left(\mathbf{L}^{\mathbf{1}^{*}} \mathbf{S C H}_{3}\right)(\mathrm{Cl})\right]_{2}\left(\mathrm{CuCl}_{4}\right),\left[\mathrm{Cu}^{\mathrm{II}}\left(\mathbf{L}^{\mathbf{2}} \mathbf{S C H}_{3}\right)-\right.$ $(\mathrm{Cl})]\left(\mathrm{BF}_{4}\right), \quad\left[\mathrm{Cu}^{\mathrm{II}}\left(\mathbf{L}^{\mathbf{3}} \mathbf{S C H}_{3}\right)(\mathrm{Cl})\right]\left(\mathrm{BF}_{4}\right)$ and $\left[\mathrm{Cu}^{\mathrm{II}}\left(\mathbf{L}^{\mathbf{1}} \mathbf{N H}_{2}\right)(\mathrm{Cl})\right]\left(\mathrm{BF}_{4}\right)$. The copper ions in the polymeric structures $\left[\mathrm{Cu}_{2}^{\mathrm{II}}\left(\mathbf{L}^{1} \mathbf{S S L}^{\mathbf{1}}\right)\right.$ $\left.(\mathrm{Cl})_{2}\right]_{n}\left(\mathrm{BF}_{4}\right)_{2 n}, \quad\left[\mathrm{Cu}_{2}^{\mathrm{II}}\left(\mathbf{L}^{2} \mathbf{S S L}^{2}\right)(\mathrm{Cl})_{2}\right]_{n}\left(\mathrm{ClO}_{4}\right)_{2 n}$ and $\left[\mathrm{Cu}_{2}^{\mathrm{II}}\left(\mathbf{L}^{\mathbf{1}} \mathbf{S L}^{\mathbf{1}}\right)-\right.$ $\left.(\mathrm{Cl})_{2}\right]_{n}\left(\mathrm{BF}_{4}\right)_{2 n}$ have very similar coordination geometries; $\left[\mathrm{Cu}_{2}^{\mathrm{II}}\left(\mathbf{L}^{\mathbf{1}} \mathbf{S S L}^{\mathbf{1}}\right)(\mathrm{Cl})_{2}\right]_{n}\left(\mathrm{BF}_{4}\right)_{2 n}$ and $\left[\mathrm{Cu}_{2}^{\mathrm{II}}\left(\mathbf{L}^{2} \mathbf{S S L}^{2}\right)(\mathrm{Cl})_{2}\right]_{n}\left(\mathrm{ClO}_{4}\right)_{2 n}$ will not be discussed, but crystallographic data and selected bond distances and angles can be found in the ESI. $\dagger$ Similarly, the structures of $\left[\mathrm{Cu}^{\mathrm{II}}\left(\mathbf{L}^{\mathbf{1}} \mathbf{S C H}_{3}\right)(\mathrm{Cl})\right]\left(\mathrm{BF}_{4}\right), \quad\left[\mathrm{Cu}^{\mathrm{II}}\left(\mathbf{L}^{\mathbf{1}}{ }^{*} \mathbf{S C H} \mathbf{H}_{3}\right)\right.$ $(\mathrm{Cl})]_{2}\left(\mathrm{CuCl}_{4}\right)$ and $\left[\mathrm{Cu}^{\mathrm{II}}\left(\mathbf{L}^{2} \mathbf{S C H} \mathbf{H}_{3}\right)(\mathrm{Cl})\right]\left(\mathrm{BF}_{4}\right)$ are comparable to that of $\left[\mathrm{Cu}^{\mathrm{II}}\left(\mathbf{L}^{\mathbf{1}} \mathbf{S C H}_{3}\right)(\mathrm{Cl})\right]\left(\mathrm{BF}_{4}\right)$ and detailed information concerning these structures can be found in the ESI. $\uparrow$ Thus, the structures of $\left[\mathrm{Cu}_{2}^{\mathrm{II}}\left(\mathbf{L}^{\mathbf{1}} \mathbf{S L}^{\mathbf{1}}\right)(\mathrm{Cl})_{2}\right]_{n}\left(\mathrm{BF}_{4}\right)_{2 n},\left[\mathrm{Cu}_{2}^{\mathrm{II}}\left(\mathbf{L}^{\mathbf{1}} \mathbf{C}_{\mathbf{6}} \mathbf{L}^{\mathbf{1}}\right)\right.$ $\left.(\mathrm{Cl})_{2}\right]_{n}\left(\mathrm{BF}_{4}\right)_{2 n}, \quad\left[\mathrm{Cu}^{\mathrm{II}}\left(\mathbf{L}^{\mathbf{1}} \mathbf{S C H}_{3}\right)(\mathrm{Cl})\right]\left(\mathrm{BF}_{4}\right),\left[\mathrm{Cu}^{\mathrm{II}}\left(\mathbf{L}^{3} \mathbf{S} \mathbf{C H}_{3}\right)(\mathrm{Cl})\right]\left(\mathrm{BF}_{4}\right)$, and $\left[\mathrm{Cu}^{\mathrm{II}}\left(\mathbf{L}^{\mathbf{1}} \mathbf{N H}_{2}\right)(\mathrm{Cl})\right]\left(\mathrm{BF}_{4}\right)$ are described. The crystallographic and structure refinement data for these complexes are collected in Table 1.

Single crystals of $\left[\mathrm{Cu}_{2}^{\mathrm{II}}\left(\mathbf{L}^{\mathbf{1}} \mathbf{S L}^{\mathbf{1}}\right)(\mathrm{Cl})_{2}\right]_{n}\left(\mathrm{BF}_{4}\right)_{2 n}$ were obtained by slow evaporation of diethyl ether into a solution of the complex in acetonitrile. A displacement ellipsoid plot of $\left[\mathrm{Cu}_{2}^{\mathrm{II}}\left(\mathbf{L}^{\mathbf{1}} \mathbf{S L}^{\mathbf{1}}\right)(\mathrm{Cl})_{2}\right]_{n}\left(\mathrm{BF}_{4}\right)_{2 n}$ is shown in Fig. 3 and selected bond distances and angles are provided in Table 2. The structure of $\left[\mathrm{Cu}_{2}^{\mathrm{II}}\left(\mathbf{L}^{\mathbf{1}} \mathbf{S L}^{\mathbf{1}}\right)(\mathrm{Cl})_{2}\right]_{n}\left(\mathrm{BF}_{4}\right)_{2 n}$ is very disordered; both the $\mathrm{Cu}$ complex and the $\mathrm{BF}_{4}{ }^{-}$counterions are disordered over two orientations. The major and minor components of the $\mathrm{Cu}$ complex are related by a pseudo-mirror plane; the occupancy factor of the major component of the disorder refines to $0.840(3)$. Both counterions are found at sites of twofold axial symmetry, and are thus constrained to be disordered with an occupancy factor of 0.5 . The thioether sulfur atom of the dinucleating ligand bridges between the two copper ions, resulting in a distorted octahedral $\mathrm{N}_{3} \mathrm{SCl}_{2}$ coordination environment for both copper ions. The elongated Jahn-Teller axis is occupied

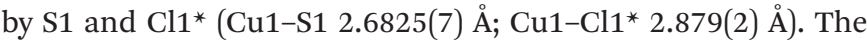
chloride ions are bridging between copper ions of neighboring dinuclear complexes resulting in infinite 1D zig-zag chains. The distance between the copper ions in the $\mathrm{Cu}(\mu-\mathrm{Cl})_{2} \mathrm{Cu}$ core is 3.6986(7) $\AA$. This distance is slightly larger than the $\mathrm{Cu} \cdots \mathrm{Cu}$ distances in $\left[\mathrm{Cu}_{2}^{\mathrm{II}}\left(\mathbf{L}^{\mathbf{1}} \mathbf{S S L} \mathbf{1}^{\mathbf{1}}\right)(\mathrm{Cl})_{2}\right]_{n}\left(\mathrm{BF}_{4}\right)_{2 n}$ and $\left[\mathrm{Cu}_{2}^{\mathrm{II}}\left(\mathbf{L}^{2} \mathbf{S S L}^{\mathbf{2}}\right)\right.$ $\left.(\mathrm{Cl})_{2}\right]_{n}\left(\mathrm{BF}_{4}\right)_{2 n}$, which are ca. $3.60 \AA$ (average) and 3.6455(4) $\mathrm{\AA}$, respectively (Table $\mathrm{S} 2 \dagger$ ).

$\left[\mathrm{Cu}_{2}^{\mathrm{II}}\left(\mathbf{L}^{\mathbf{1}} \mathbf{C}_{6} \mathbf{L}^{\mathbf{1}}\right)(\mathrm{Cl})_{2}\right]_{n}\left(\mathrm{BF}_{4}\right)_{2 n} \cdot 4 \mathrm{CH}_{3} \mathrm{CN}$ crystallized from acetonitrile and di-isopropyl ether. The metal and chloride ions and the 1,6-diaminohexane backbone are lying in a mirror plane and in addition the molecule contains two-fold rotational symmetry; the $\mathrm{BF}_{4}{ }^{-}$anion is disordered on a twofold axis, and the acetonitrile molecule is located on a general position. The asymmetric unit consequently contains $1 / 4$ of the ligand, half a copper center, half a $\mathrm{Cl}^{-}$ion, half $\mathrm{a} \mathrm{BF}_{4}{ }^{-}$ion and one $\mathrm{CH}_{3} \mathrm{CN}$ molecule. A displacement ellipsoid plot is shown in Fig. 4, selected bond distances and angles can be found in Table 2 . The copper ions in $\left[\mathrm{Cu}_{2}^{\mathrm{II}}\left(\mathbf{L}^{\mathbf{1}} \mathbf{C}_{\mathbf{6}} \mathbf{L}^{\mathbf{1}}\right)(\mathrm{Cl})_{2}\right]_{n}\left(\mathrm{BF}_{4}\right)_{2 n}$ are in an $\mathrm{N}_{3} \mathrm{Cl}_{2}$ coordination environment, in a distorted square-pyramidal geometry that resembles that of the copper ions in $\left[\mathrm{Cu}_{2}^{\mathrm{II}}\left(\mathbf{L}^{1} \mathbf{S L}^{\mathbf{1}}\right)\right.$ $\left.(\mathrm{Cl})_{2}\right]_{n}\left(\mathrm{BF}_{4}\right)_{2 n}$, except for the coordination of a sulfur atom. The chloride ions are bridging between copper ions of neighboring 
Table 1 Crystallographic and structure refinement data for $\left[\mathrm{Cu}_{2}^{\prime \prime}\left(\mathrm{L}^{1} \mathrm{SL}^{1}\right)\left(\mathrm{Cl}_{2}\right]_{n}\left(\mathrm{BF}_{4}\right)_{2 n},\left[\mathrm{Cu}_{2}^{\prime \prime}\left(\mathrm{L}^{1} \mathrm{C}_{6} \mathrm{~L}^{1}\right)(\mathrm{Cl})_{2}\right]_{n}\left(\mathrm{BF}_{4}\right)_{2 n},\left[\mathrm{Cu}^{\prime \prime}\left(\mathrm{L}^{1} \mathrm{SCH}_{3}\right)(\mathrm{Cl})\right]\left(\mathrm{BF}_{4}\right),\left[\mathrm{Cu}^{\prime \prime}\left(\mathrm{L}^{3} \mathrm{SCH}_{3}\right)(\mathrm{Cl})\right]\left(\mathrm{BF} \mathrm{C}_{4}\right)\right.$ and $\left[\mathrm{Cu}^{\prime \prime}\left(\mathrm{L}^{1} \mathrm{NH}_{2}\right)(\mathrm{Cl})\right]\left(\mathrm{BF}_{4}\right)$

\begin{tabular}{|c|c|c|c|c|c|}
\hline & $\begin{array}{l}{\left[\mathrm{Cu}_{2}^{\mathrm{II}}\left(\mathbf{L}^{\mathbf{1}} \mathbf{S L}^{\mathbf{1}}\right)(\mathrm{Cl})_{2}\right]_{n^{-}}} \\
\left(\mathrm{BF}_{4}\right)_{2 n}\end{array}$ & $\begin{array}{l}{\left[\mathrm{Cu}_{2}^{\mathrm{II}}\left(\mathbf{L}^{\mathbf{1}} \mathbf{C}_{\mathbf{6}} \mathbf{L}^{\mathbf{1}}\right)(\mathrm{Cl})_{2}\right]_{n^{-}}} \\
\left(\mathrm{BF}_{4}\right)_{2 n}\end{array}$ & $\begin{array}{l}{\left[\mathrm{Cu}^{\mathrm{II}}\left(\mathbf{L}^{\mathbf{1}} \mathbf{S C H}_{3}\right)(\mathrm{Cl})\right]-} \\
\left(\mathrm{BF}_{4}\right)\end{array}$ & $\begin{array}{l}{\left[\mathrm{Cu}^{\mathrm{II}}\left(\mathbf{L}^{3} \mathbf{S C H}_{3}\right)(\mathrm{Cl})\right]-} \\
\left(\mathrm{BF}_{4}\right)\end{array}$ & $\begin{array}{l}{\left[\mathrm{Cu}^{\mathrm{II}}\left(\mathbf{L}^{\mathbf{1}} \mathbf{N H}_{2}\right)(\mathrm{Cl})\right]-} \\
\left(\mathrm{BF}_{4}\right)\end{array}$ \\
\hline Empirical formula & $\begin{array}{l}{\left[\mathrm{C}_{28} \mathrm{H}_{32} \mathrm{Cl}_{2} \mathrm{Cu}_{2} \mathrm{~N}_{6} \mathrm{~S}\right]-} \\
\left(\mathrm{BF}_{4}\right)_{2}\end{array}$ & $\begin{array}{l}{\left[\mathrm{C}_{30} \mathrm{H}_{36} \mathrm{Cl}_{2} \mathrm{Cu}_{2} \mathrm{~N}_{6}\right]-} \\
\left(\mathrm{BF}_{4}\right)_{2} \cdot 4 \mathrm{CH}_{3} \mathrm{CN}\end{array}$ & $\begin{array}{l}{\left[\mathrm{C}_{15} \mathrm{H}_{19} \mathrm{ClCuN}_{3} \mathrm{~S}\right]-} \\
\left(\mathrm{BF}_{4}\right)\end{array}$ & $\begin{array}{l}{\left[\mathrm{C}_{17} \mathrm{H}_{23} \mathrm{ClCuN}_{3} \mathrm{~S}\right]-} \\
\left(\mathrm{BF}_{4}\right)\end{array}$ & $\begin{array}{l}{\left[\mathrm{C}_{14} \mathrm{H}_{18} \mathrm{ClCuN}_{4}\right]-} \\
\left(\mathrm{BF}_{4}\right)\end{array}$ \\
\hline Formula weight & 856.25 & 1016.46 & 459.19 & 487.24 & 428.12 \\
\hline Crystal system & Monoclinic & Monoclinic & Triclinic & Monoclinic & Monoclinic \\
\hline Space group & $C 2 / c$ & $C 2 / m$ & $P \overline{1}$ & $P 2_{1} / c$ & $P 2_{1} / n$ \\
\hline$a(\AA)$ & $10.0603(8)$ & $13.287(2)$ & 7.45273(18) & $9.11412(10)$ & $8.92176(15)$ \\
\hline$b(\AA)$ & $23.2653(15)$ & $27.558(5)$ & $11.2448(3)$ & $15.17627(13)$ & $12.8949(3)$ \\
\hline$c(\AA)$ & $14.5686(9)$ & $6.9232(17)$ & $12.3634(3)$ & $15.31060(15)$ & $14.9606(3)$ \\
\hline$\alpha\left(^{\circ}\right)$ & 90 & 90 & $65.993(3)$ & 90 & 90 \\
\hline$\left.\beta()^{\circ}\right)$ & $100.321(7)$ & $111.421(13)$ & $74.934(2)$ & $102.6105(10)$ & $102.0565(19)$ \\
\hline$\gamma\left({ }^{\circ}\right)$ & 90 & 90 & $88.273(2)$ & 90 & 90 \\
\hline$V\left(\AA^{3}\right)$ & $3354.7(4)$ & 2359.9(8) & $910.58(4)$ & 2066.65(4) & $1683.18(6)$ \\
\hline$Z$ & 4 & 2 & 2 & 4 & 4 \\
\hline$D_{\text {calc }}\left(\mathrm{g} \mathrm{cm}^{3}\right)$ & 1.695 & 1.430 & 1.675 & 1.566 & 1.689 \\
\hline$T$ (Kelvin) & $110(2)$ & $150(2)$ & $110(2)$ & $110(2)$ & $110(2)$ \\
\hline Crystal size, $\mathrm{mm}$ & $0.43 \times 0.14 \times 0.08$ & $0.30 \times 0.30 \times 0.30$ & $0.36 \times 0.28 \times 0.22$ & $0.40 \times 0.32 \times 0.22$ & $0.50 \times 0.36 \times 0.14$ \\
\hline$\mu\left(\mathrm{mm}^{-1}\right)$ & 1.566 & 1.085 & 1.504 & 4.021 & 1.502 \\
\hline No. of reflns measd & 9412 & 9970 & 28025 & 14162 & 13962 \\
\hline No. of unique reflns & 2953 & 1904 & 4179 & 4035 & 3879 \\
\hline No. of reflns obsd. $[I>2 \sigma(I)]$ & 2550 & 1601 & 3994 & 3893 & 3414 \\
\hline No. of parameters & 444 & 172 & 282 & 303 & 234 \\
\hline$R_{1} / \mathrm{w} R_{2}[I>2 \sigma(I)]$ & $0.0538 / 0.1394$ & $0.0780 / 0.2007$ & $0.0187 / 0.0486$ & $0.0240 / 0.0635$ & $0.0257 / 0.0675$ \\
\hline$R_{1} / \mathrm{w} R_{2}$ [all refl.] & $0.0621 / 0.1452$ & $0.0942 / 0.2123$ & $0.0197 / 0.0491$ & $0.0250 / 0.0641$ & $0.0305 / 0.0693$ \\
\hline Goodness of fit & 1.029 & 1.151 & 1.043 & 1.054 & 1.080 \\
\hline$\Delta \rho\left(\mathrm{e} \AA^{-3}\right)$ & $-0.57 / 0.81$ & $-1.22 / 1.04$ & $-0.30 / 0.36$ & $-0.30 / 0.39$ & $-0.48 / 0.31$ \\
\hline
\end{tabular}

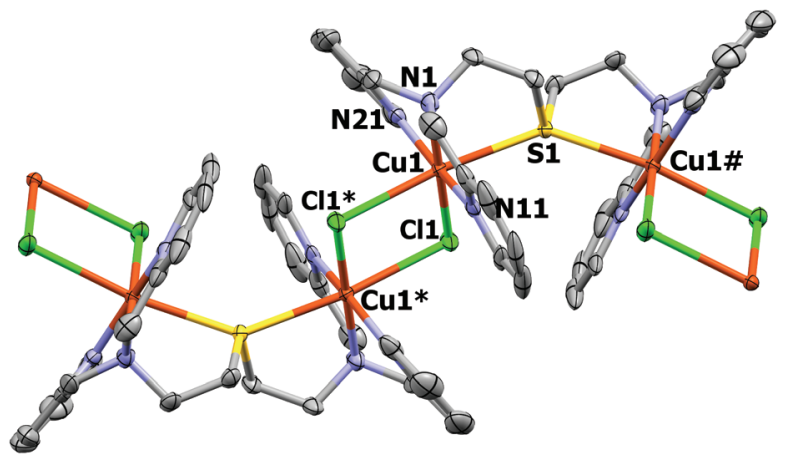

Fig. 3 Displacement ellipsoid plot (50\% probability level) of two of the repeating units in the cationic polymer chain of $\left[\mathrm{Cu}_{2}^{\prime \prime}\left(\mathrm{L}^{1} \mathrm{SL}^{1}\right)(\mathrm{Cl})_{2}\right]_{n}\left(\mathrm{BF}_{4}\right)_{2 n}$. The disorder, the non-coordinating counterions and hydrogen atoms are omitted for clarity. Symmetry operation * $=[1-x,-y,-z]$ and $\#=$ $[1-x, y, 1 / 2-z]$.

dinuclear complexes resulting in infinite linear 1D chains. The $\mathrm{Cu} 1-\mathrm{Cu} 1 *$ distance in the $\mathrm{Cu}(\mu-\mathrm{Cl})_{2} \mathrm{Cu}$ core is 3.405(2) $\AA$, which is significantly smaller than in sulfur-containing complexes such as $\left[\mathrm{Cu}_{2}^{\mathrm{II}}\left(\mathbf{L}^{1} \mathbf{S L}^{\mathbf{1}}\right)(\mathrm{Cl})_{2}\right]_{n}\left(\mathrm{BF}_{4}\right)_{2 n}$. The structure of the related dinuclear complex $\left[\mathrm{Cu}_{2}^{\mathrm{II}}\left(\mathbf{L}^{1} \mathbf{C}_{6} \mathbf{L}^{1}\right)(\mathrm{Cl})_{4}\right]$, which does not form polymeric structures, was recently reported; $;^{29}$ the copper ions in the two structures have very similar coordination geometries (Fig. S6†). The major difference between the structures is that the hexamethylene bridge in $\left[\mathrm{Cu}_{2}^{\mathrm{II}}\left(\mathbf{L}^{1} \mathbf{C}_{6} \mathbf{L}^{\mathbf{1}}\right)(\mathrm{Cl})_{4}\right]$ has a crystallographic $C_{2 \mathrm{~h}}$ symmetry and forms an 'alternating' chain whereas in $\left[\mathrm{Cu}_{2}^{\mathrm{II}}\left(\mathbf{L}^{1} \mathbf{C}_{6} \mathbf{L}^{1}\right)\left(\mathrm{Cl}_{2}\right]_{n}\left(\mathrm{BF}_{4}\right)_{2 n}\right.$ it forms a linear
Table 2 Selected bond distances $(\AA)$ and bond angles $\left(^{\circ}\right.$ ) for $\left[\mathrm{Cu}_{2}^{\prime \prime}\left(\mathrm{L}^{1} \mathrm{SL}^{1}\right)(\mathrm{Cl})_{2}\right]_{n}\left(\mathrm{BF}_{4}\right)_{2 n}$ and $\left[\mathrm{Cu}_{2}^{\prime \prime}\left(\mathrm{L}^{1} \mathrm{C}_{6} \mathrm{~L}^{1}\right)(\mathrm{Cl})_{2}\right]_{n}\left(\mathrm{BF}_{4}\right)_{2 n}{ }^{a}$

\begin{tabular}{lll}
\hline & $\begin{array}{l}{\left[\mathrm{Cu}_{2}^{\mathrm{II}}\left(\mathbf{L}^{\mathbf{1}} \mathbf{S L}^{\mathbf{1}}\right)-\right.} \\
\left.(\mathrm{Cl})_{2}\right]_{n}\left(\mathrm{BF}_{4}\right)_{2 n}\end{array}$ & $\begin{array}{l}{\left[\mathrm{Cu}_{2}^{\mathrm{II}}\left(\mathbf{L}^{\mathbf{1}} \mathbf{C}_{6} \mathbf{L}^{\mathbf{1}}\right)-\right.} \\
\left.(\mathrm{Cl})_{2}\right]_{n}\left(\mathrm{BF}_{4}\right)_{2 n}\end{array}$ \\
\hline Cu1-Cu1* & $3.6986(7)$ & $3.405(2)$ \\
Cu1-Cu1\# & $5.0511(7)$ & $12.013(3)$ \\
Cu1-S1 & $2.6825(7)$ & \\
Cu1-N1 & $2.057(4)$ & $2.026(9)$ \\
Cu1-N11/N2 & $2.004(4)$ & $1.987(6)$ \\
Cu1-N21/N2 & $1.987(4)$ & $1.987(6)$ \\
Cu1-Cl1 & $2.278(2)$ & $2.223(3)$ \\
Cu1-Cl1* & $2.879(2)$ & \\
S1-Cu1-N1 & $84.72(12)$ & \\
S1-Cu1-N11 & $83.29(11)$ & \\
S1-Cu1-N21 & $100.27(11)$ & \\
S1-Cu1-Cl1* & $166.13(5)$ & $82.88(18)$ \\
N1-Cu1-N11/N2 & $82.77(18)$ & $173.7(3)$ \\
N1-Cu1-N21/N2' & $80.87(17)$ & $165.5(4)$ \\
N1-Cu1-Cl1 & $177.93(13)$ & \\
N11-Cu1-N21/N2' & $162.84(18)$ &
\end{tabular}

${ }^{a}$ Symmetry operation $*=[1-x,-y,-z]$ and $\#=[1-x, y, 1 / 2-z]$ for $\left[\mathrm{Cu}_{2}^{\mathrm{II}}\left(\mathbf{L}^{1} \mathbf{S L}^{1}\right)(\mathrm{Cl})_{2}\right]_{n}\left(\mathrm{BF}_{4}\right)_{2 n}$; symmetry operation * $=[1-x, y, 1-z]$; $\#=[-x, y,-1-z] ;^{\prime}=[x,-y, z]$ for $\left[\mathrm{Cu}_{2}^{\mathrm{II}}\left(\mathbf{L}^{1} \mathbf{C}_{6} \mathbf{L}^{1}\right)(\mathrm{Cl})_{2}\right]_{n}\left(\mathrm{BF}_{4}\right)_{2 n}$.

chain, which is the expected, thermodynamically favored conformation.

The three compounds $\left[\mathrm{Cu}^{\mathrm{II}}\left(\mathbf{L}^{\mathbf{1}} \mathbf{S} \mathbf{C H}_{3}\right)(\mathrm{Cl})\right]\left(\mathrm{BF}_{4}\right),\left[\mathrm{Cu}^{\mathrm{II}}\left(\mathbf{L}^{3} \mathbf{S} \mathbf{C H}_{3}\right)-\right.$ $(\mathrm{Cl})]\left(\mathrm{BF}_{4}\right)$ and $\left[\mathrm{Cu}^{\mathrm{II}}\left(\mathbf{L}^{1} \mathbf{N H}_{2}\right)(\mathrm{Cl})\right]\left(\mathrm{BF}_{4}\right)$ all crystallized with one mononuclear complex cation and one $\mathrm{BF}_{4}{ }^{-}$counterion in the asymmetric unit. Displacement ellipsoid plots and selected bond distances and angles are given in Fig. 5 and Table 3. 


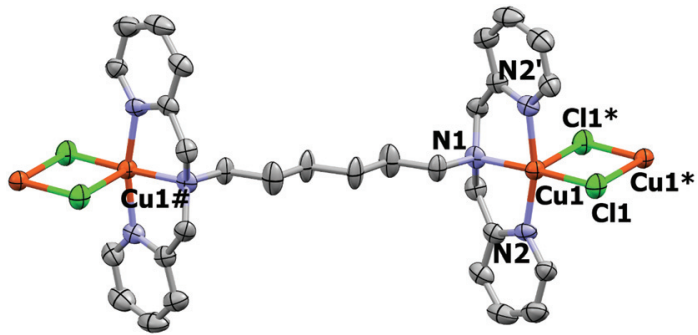

Fig. 4 Displacement ellipsoid plot (50\% probability level) of the cationic part of $\left[\mathrm{Cu}_{2}^{\prime \prime}\left(\mathrm{L}^{1} \mathrm{C}_{6} \mathrm{~L}^{1}\right)(\mathrm{Cl})_{2}\right]_{n}\left(\mathrm{BF}_{4}\right)_{2 n}$. Non-coordinating $\mathrm{BF}_{4}{ }^{-}$counterions, acetonitrile solvent molecules and hydrogen atoms are omitted for clarity. Symmetry operation * $=[1-x, y, 1-z] ; \#=[-x, y,-1-z]$; ' $=[x,-y, z]$.

The structure of $\left[\mathrm{Cu}^{\mathrm{II}}\left(\mathbf{L}^{\mathbf{1}} \mathbf{S C H}_{3}\right)(\mathrm{Cl})\right]\left(\mathrm{BF}_{4}\right)$ is mostly ordered. The $\mathrm{BF}_{4}{ }^{-}$counterion is disordered over two orientations, and the occupancy factor of the major component refines to $0.70(3)$. The copper ion has square-pyramidal geometry $(\tau=0.16),{ }^{30}$ but the complex can also be considered a dimer when the chloride ions that bridge between two copper ions are taken into account, thus creating an octahedral environment with $\mathrm{Cl}^{*}$ and $\mathrm{S} 1$ on the elongated Jahn-Teller axis (Cu1-S1 2.7152(4)

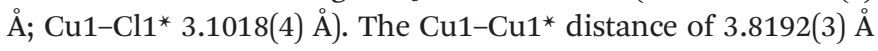
is larger than in the polymeric species discussed above. Formation of such dimeric structures is also observed for $\left[\mathrm{Cu}^{\mathrm{II}}\left(\mathbf{L}^{2} \mathbf{S C H} \mathbf{H}_{3}\right)(\mathrm{Cl})\right]\left(\mathrm{BF}_{4}\right), \quad\left[\mathrm{Cu}^{\mathrm{II}}\left(\mathbf{L}^{\mathbf{1} *} \mathbf{S C H} \mathbf{H}_{3}\right)(\mathrm{Cl})\right]\left(\mathrm{BF}_{4}\right)$ and $\left[\mathrm{Cu}^{\mathrm{II}}\left(\mathbf{L}^{\mathbf{1}}{ }^{*} \mathbf{S C H}_{3}\right)(\mathrm{Cl})\right]_{2}\left(\mathrm{CuCl}_{4}\right) \quad(\mathrm{ESI} \dagger)$. The compounds $\left[\mathrm{Cu}^{\mathrm{II}}\left(\mathbf{L}^{3} \mathbf{S C H}_{3}\right)(\mathrm{Cl})\right]\left(\mathrm{BF}_{4}\right)$ and $\left[\mathrm{Cu}^{\mathrm{II}}\left(\mathbf{L}^{\mathbf{1}} \mathbf{N H}_{2}\right)(\mathrm{Cl})\right]\left(\mathrm{BF}_{4}\right)$ do not form dimeric species, as their coordination geometry is more distorted towards trigonal bipyramidal with $\tau$ parameters of 0.39 and 0.84 , respectively. In $\left[\mathrm{Cu}^{\mathrm{II}}\left(\mathbf{L}^{\mathbf{1}} \mathbf{N H}_{2}\right)(\mathrm{Cl})\right]\left(\mathrm{BF}_{4}\right)$ the $\mathrm{Cl}^{-}$ion and the tertiary nitrogen atom occupy the axial coordination sites, whereas in $\left[\mathrm{Cu}^{\mathrm{II}}\left(\mathbf{L}^{3} \mathbf{S} \mathbf{C H}_{3}\right)(\mathrm{Cl})\right]\left(\mathrm{BF}_{4}\right)$ these positions are occupied by the pyridyl nitrogens. A structure similar to $\left[\mathrm{Cu}^{\mathrm{II}}\left(\mathbf{L}^{\mathbf{1}} \mathbf{N H}_{2}\right)(\mathrm{Cl})\right]\left(\mathrm{BF}_{4}\right)$ has been reported in the literature with $\mathrm{ClO}_{4}{ }^{-}$instead of $\mathrm{BF}_{4}{ }^{-}$as the non-coordinating counterion. ${ }^{31}$

\subsection{Catechol oxidation}

The synthesized complexes were tested for their catalytic activity in the oxidation of 3,5-DTBC to 3,5-DTBQ. The rate of oxidation was determined by monitoring the absorbance of 3,5-DTBQ at $400 \mathrm{~nm}$. All catalytic experiments were conducted
Table 3 Selected bond distances $(\AA \AA)$ and bond angles $\left(^{\circ}\right.$ ) for $\left[\mathrm{Cu}^{\prime \prime}\left(\mathrm{L}^{1} \mathrm{SCH}_{3}\right)(\mathrm{Cl})\right]\left(\mathrm{BF}_{4}\right),\left[\mathrm{Cu}^{\prime \prime}\left(\mathrm{L}^{3} \mathrm{SCH}_{3}\right)(\mathrm{Cl})\right]\left(\mathrm{BF}_{4}\right)$ and $\left[\mathrm{Cu}^{\prime \prime}\left(\mathrm{L}^{1} \mathrm{NH}_{2}\right)(\mathrm{Cl})\right]\left(\mathrm{BF}_{4}\right)^{a}$

\begin{tabular}{llll}
\hline & $\begin{array}{lll}{\left[\mathrm{Cu}^{\mathrm{II}}\left(\mathbf{L}^{\mathbf{1}} \mathbf{S C H}_{3}\right)-\right.} \\
(\mathrm{Cl})]\left(\mathrm{BF}_{4}\right)\end{array}$ & $\begin{array}{l}{\left[\mathrm{Cu}^{\mathrm{II}}\left(\mathbf{L}^{3} \mathbf{S C H}_{3}\right)-\right.} \\
(\mathrm{Cl})]\left(\mathrm{BF}_{4}\right)\end{array}$ & $\begin{array}{l}{\left[\mathrm{Cu}^{\mathrm{II}}\left(\mathbf{L}^{\mathbf{1}} \mathbf{N H}_{2}\right)\right.} \\
(\mathrm{Cl})]\left(\mathrm{BF}_{4}\right)\end{array}$ \\
\hline Cu1-Cu1* & $3.8192(3)$ & & \\
Cu1-S1/N2 & $2.7152(4)$ & $2.5817(4)$ & $2.0593(15)$ \\
Cu1-N1 & $2.0558(10)$ & $2.0876(12)$ & $2.0439(12)$ \\
Cu1-N11 & $1.9782(11)$ & $1.9914(12)$ & $2.1158(13)$ \\
Cu1-N21 & $1.9845(11)$ & $1.9935(13)$ & $2.0410(13)$ \\
Cu1-Cl1 & $2.2588(3)$ & $2.2674(4)$ & $2.2381(4)$ \\
Cu1-Cl1 & $3.1018(4)$ & & \\
S1/N2-Cu1-N1 & $85.93(3)$ & $85.75(3)$ & $84.73(5)$ \\
S1/N2-Cu1-N11 & $101.67(3)$ & $93.86(4)$ & $109.75(6)$ \\
S1/N2-Cu1-N21 & $84.59(3)$ & $82.92(4)$ & $127.21(6)$ \\
S1/N2-Cu1-Cl1 & $100.430(11)$ & $141.526(16)$ & $96.44(4)$ \\
N1-Cu1-N11 & $82.43(4)$ & $82.13(5)$ & $80.25(5)$ \\
N1-Cu1-N21 & $83.42(4)$ & $83.00(5)$ & $81.87(5)$ \\
N1-Cu1-Cl1 & $173.64(3)$ & $132.50(4)$ & $177.49(4)$ \\
N11-Cu1-N21 & $164.06(4)$ & $164.98(5)$ & $117.72(5)$ \\
N11-Cu1-Cl1 & $96.15(3)$ & $95.44(4)$ & $97.26(4)$ \\
N21-Cu1-Cl1 & $97.09(3)$ & $96.15(4)$ & $99.12(4)$ \\
${ }^{a}$ Symmetry operation $*=[1-x, 2-y, 1-z]$. & \\
& & &
\end{tabular}

at $25{ }^{\circ} \mathrm{C}$ whilst stirring and bubbling a mixture of $\mathrm{N}_{2}$ and $\mathrm{O}_{2}$ $(1: 1)$ through the solution; the amount of $\mathrm{O}_{2}$ supplied in the reactions was not rate-limiting as small changes in the rate of dioxygen flow did not result in noticeable differences in the initial turnover frequencies (TOFs). A copper concentration of $0.4 \mathrm{mM}$, corresponding with $0.4 \mathrm{mM}$ of a mononuclear complex or $0.2 \mathrm{mM}$ of a dinuclear complex, was used together with $20 \mathrm{mM}$ 3,5-DTBC. Upon addition of $20 \mathrm{mM} \mathrm{NEt}_{3}$ the conversion of 3,5-DTBC started; the final solution thus contained a $1: 50: 50$ ratio of $[\mathrm{Cu}]:$ substrate : base. The results of the catalytic experiments are collected in Table 4. Three different types of conversion curves were observed (A, B and C; Fig. 6). Depending on the type of catalyst the oxidation rate was constant, increasing, or decreasing over time. For this reason both the maximum and initial TOFs are reported in Table 4. After addition of $\mathrm{NEt}_{3}$, an abrupt increase in the absorption at $400 \mathrm{~nm}$ was observed for all copper complexes with one $\mathrm{Cl}^{-}$and one $\mathrm{BF}_{4}{ }^{-}$counterion (Fig. 6). The height of this 'jump' was dependent on the catalyst used and appeared to be related to the presence of chloride ions (see below). The initial TOF was determined by taking the tangent of the curve of the first two seconds after the 'jump' in the absorption curve. Blank reactions were performed in the presence and absence of
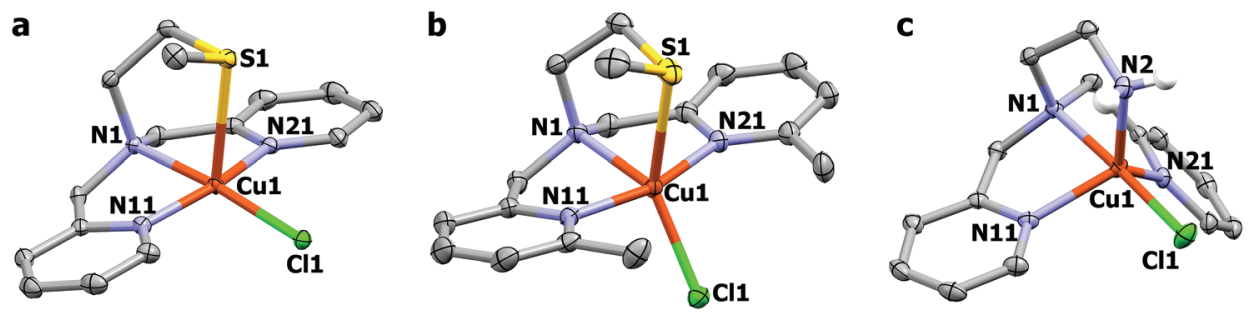

Fig. 5 Displacement ellipsoid plots (50\% probability level) of the cationic parts of (a) $\left[\mathrm{Cu}^{\prime \prime}\left(\mathrm{L}^{1} \mathrm{SCH}_{3}\right)(\mathrm{Cl})\right]\left(\mathrm{BF}_{4}\right),(\mathrm{b})\left[\mathrm{Cu}^{\prime \prime}\left(\mathrm{L}^{3} \mathrm{SCH}_{3}\right)(\mathrm{Cl})\right]\left(\mathrm{BF}_{4}\right)$ and $(\mathrm{c})$ $\left[\mathrm{Cu}^{\prime \prime}\left(\mathrm{L}^{1} \mathrm{NH}_{2}\right)(\mathrm{Cl})\right]\left(\mathrm{BF}_{4}\right)$. The non-coordinating counterions and most of the hydrogen atoms are omitted for clarity. 
Table 4 Turnover frequencies of the oxidation of 3,5-DTBC to 3,5-DTBQ catalyzed by copper complexes with different ligands ${ }^{a}$

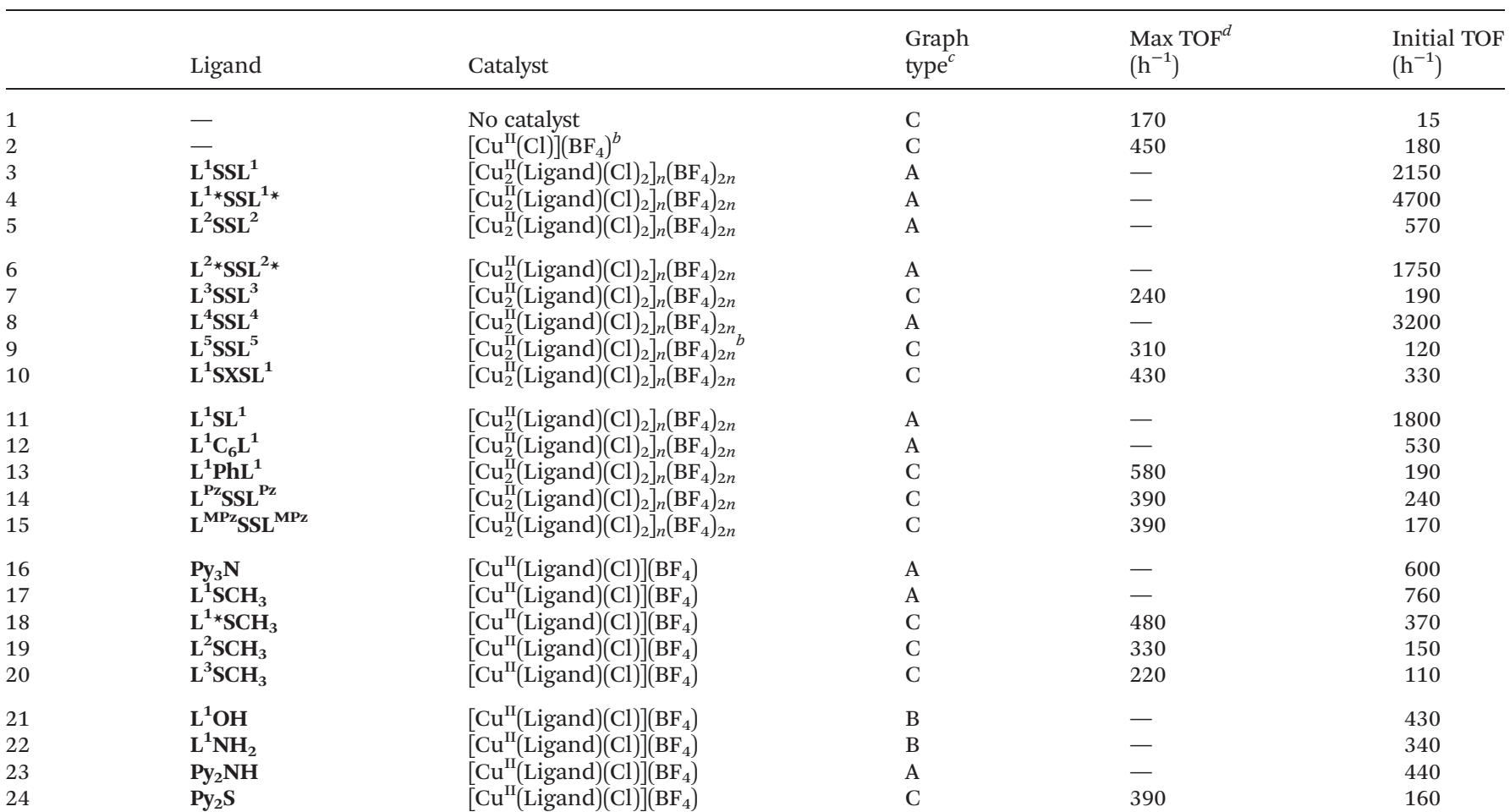

${ }^{a}$ Reaction conditions: $[\mathrm{Cu}]=0.4 \mathrm{mM} ; 3,5-\mathrm{DTBC} / \mathrm{NEt}_{3} / \mathrm{Cu}=50 / 50 / 1 ; 3 \mathrm{~mL} \mathrm{CH}_{3} \mathrm{CN}$. TOFs were determined from the change in absorbance of 3,5-DTBQ at $400 \mathrm{~nm} .{ }^{b}$ Complex was formed in situ. ${ }^{c}$ The three different types of graphs A, B and C are depicted in Fig. $6 .{ }^{d}$ Only given when maximum TOF is higher than initial TOF (graph type C).

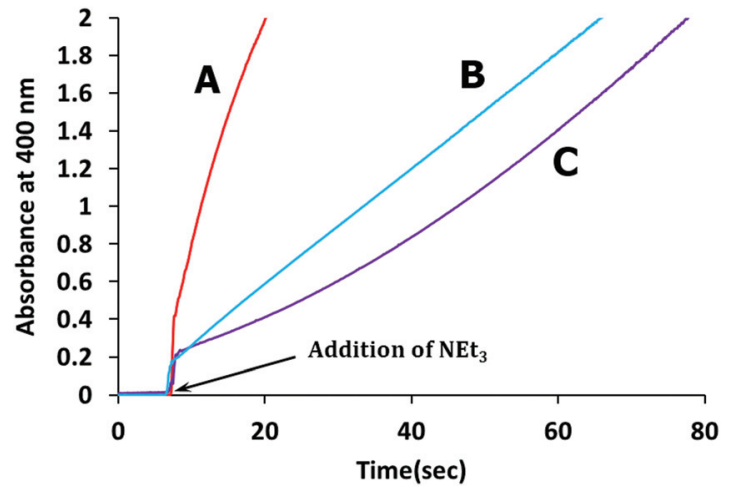

Fig. 6 Development in time of the absorption at $400 \mathrm{~nm}$ due to 3,5DTBQ formation, catalyzed by $\left[\mathrm{Cu}_{2}^{\prime \prime}\left(\mathrm{L}^{1} \mathrm{SSL}^{1}\right)(\mathrm{Cl})_{2}\right]\left(\mathrm{BF}_{4}\right)_{2}$ (red, type $\left.\mathrm{A}\right)$, $\left[\mathrm{Cu}\left(\mathrm{L}\left(\mathrm{L}^{1} \mathrm{OH}\right)(\mathrm{Cl})\right]\left(\mathrm{BF}_{4}\right)(\right.$ blue, type $\mathrm{B})$ and $\left[\mathrm{Cu}_{2}^{\prime \prime}\left(\mathrm{L}^{\mathrm{Pz}} \mathrm{SSL}^{\mathrm{Pz}}\right)(\mathrm{Cl})_{2}\right]\left(\mathrm{BF}_{4}\right)_{2}$ (purple, type C).

copper (entries 1-2, Table 4). The blank reaction with copper was performed using a 1:1 mixture in acetonitrile of $\left[\mathrm{Cu}^{\mathrm{II}}\left(\mathrm{H}_{2} \mathrm{O}\right)_{6}\right]\left(\mathrm{BF}_{4}\right)_{2}$ and $\mathrm{CuCl}_{2} \cdot 2 \mathrm{H}_{2} \mathrm{O}$ from which most of the $\mathrm{H}_{2} \mathrm{O}$ content was removed by addition of $\mathrm{Na}_{2} \mathrm{SO}_{4}$. The catalytic activity of the copper complexes with mononucleating ligands is not much higher than for the system containing just the copper salts (entries 2 and 16-24, Table 4). In contrast, a number of the dinucleating ligands result in catalytic systems with significantly higher activity, which we will further elaborate on.
The catalytic system comprising the ligand $\mathbf{L}^{\mathbf{1}} \mathbf{S S L}^{\mathbf{1}}$ shows reasonably high activity (entry 3 ), but introduction of methyl groups at the ortho-position of the pyridyl rings results in a considerable decrease of the catalytic activity (entries 3, 5 and 7). Addition of a methyl group next to the sulfur in the disulfide bond, however, results in significantly higher activity (entries 3-6). Changing the bridge between the tertiary amine and the pyridyl groups from a methylene to an ethylene spacer at two positions leads to an increase in activity (entry $3 \mathrm{vs} .8$ ), but at four positions it leads to a dramatic decrease in activity (entry 3 vs. 9). The use of pyridyl-containing ligands containing a disulfide bond generally results in higher TOFs, but the high catalytic activity of the system comprising $\mathbf{L}^{1} \mathbf{S L}^{1}$ indicates that the presence of a thioether instead of a disulfide group can give similar performance (entry 3 vs. 11). The presence of an S-donor atom in the ligand does have a positive effect on the catalytic activity of the system, considering that a similar complex with an alkane bridge $\left(\mathbf{L}^{\mathbf{1}} \mathbf{C}_{6} \mathbf{L}^{\mathbf{1}}\right)$ shows a significantly lower TOF (entry 3 vs. 12). The complex with ligand $\mathbf{L}^{1} \mathbf{S X S L}^{\mathbf{1}}$ has considerably lower activity than the compound with $\mathbf{L}^{1 *} \mathbf{S S L}^{\mathbf{1}}$, while these systems only differ in the rigidity of the ligand (entry 4 vs. 10). Such rigidity might also be a factor in the low activity of the complex with $\mathbf{L}^{\mathbf{1}} \mathbf{P h} \mathbf{L}^{\mathbf{1}}$ (entry 13). The presence of pyrazole moieties instead of pyridyl groups stabilizes the $\mathrm{Cu}^{\mathrm{I}}$ oxidation state, ${ }^{24}$ which is reflected in the negative effect on the catalytic activity (entries 14 and 15). 
Table 5 Turnover frequencies of the oxidation of 3,5-DTBC to 3,5DTBQ catalyzed by $\left[\mathrm{Cu}_{2}^{\prime \prime}\left(\mathrm{L}^{\mathrm{Pz}} \mathrm{SSL}^{\mathrm{Pz}}\right)\right]^{4+}$ in the presence of different chloride concentrations ${ }^{a}$

\begin{tabular}{lllll}
\hline Catalyst & $\begin{array}{l}\text { Graph } \\
\text { type }\end{array}$ & $\begin{array}{l}\text { Max. } \\
\text { TOF } \\
\left(h^{-1}\right)\end{array}$ & $\begin{array}{l}\text { Initial } \\
\text { TOF } \\
\left(h^{-1}\right)\end{array}$ & $\begin{array}{l}\mathrm{Cl}^{-} \\
\text {conc. } \\
(\mathrm{mM})\end{array}$ \\
\hline$\left[\mathrm{Cu}_{2}^{\mathrm{II}}\left(\mathbf{L}^{\mathbf{P z}} \mathbf{S S L}^{\mathbf{P z}}\right)\right]\left(\mathrm{BF}_{4}\right)_{4}{ }^{b}$ & $\mathrm{C}$ & 550 & 220 & 0 \\
{$\left[\mathrm{Cu}_{2}^{\mathrm{II}}\left(\mathbf{L}^{\mathbf{P z}} \mathbf{S S L}^{\mathbf{P z}}\right)\left(\mathrm{Cl}_{2}\right]\left(\mathrm{BF}_{4}\right)_{2}\right.$} & $\mathrm{C}$ & 390 & 240 & 0.4 \\
$\mathrm{Cu}_{2}^{\mathrm{II}}\left(\mathbf{L}^{\mathbf{P z}} \mathbf{S S L}^{\mathbf{P z}}\right) \mathbf{C l}_{4}{ }^{b}$ & $\mathrm{C}$ & 360 & 140 & 0.8 \\
{$\left[\mathrm{Cu}_{2}^{\mathrm{II}}\left(\mathbf{L}^{\mathbf{P z}} \mathbf{S S L}^{\mathbf{P z}}\right)\left(\mathrm{Cl}_{2}\right]\left(\mathrm{BF}_{4}\right)_{2}+\mathrm{Bu}_{4} \mathrm{NCl}\right.$} & $\mathrm{C}$ & 230 & 100 & 20
\end{tabular}

${ }^{a}$ Reaction conditions: $[\mathrm{Cu}]=0.4 \mathrm{mM} ; 3,5-\mathrm{DTBC} / \mathrm{NEt}_{3} / \mathrm{Cu}=50 / 50 / 1$; $3 \mathrm{~mL} \mathrm{CH} \mathrm{CHN}_{3} \mathrm{CNOFs}$ were determined from the change in absorbance of 3,5-DTBQ at $400 \mathrm{~nm} .{ }^{b}$ Complex was formed in situ. ${ }^{c}$ The three different types of graphs A, B and C are depicted in Fig. 6.

The catalytic activity decreases with increasing concentration of chloride ions, as can be seen in Table 5. The absorption spectra for $\left[\mathrm{Cu}_{2}^{\mathrm{II}}\left(\mathbf{L}^{\mathrm{Pz}} \mathbf{S S L}^{\mathbf{P z}}\right)\right]^{4+}$ with $1-5$ equivalents of chloride ions (in ratio to the dinuclear complex) have been recorded. The spectroscopic changes that are observed upon addition of 1-4 equivalents of chloride ions indicate coordination of the chloride ions to the copper center. During catalysis, the coordinated chloride ions will hamper binding of the substrate or activation of dioxygen. Addition of a fifth equivalent of $\mathrm{Cl}^{-}$results in formation of an absorption band at $460 \mathrm{~nm}$, which can be attributed to the formation of the complex anion $\mathrm{CuCl}_{4}{ }^{2-}$ (Fig. S9†). ${ }^{32-34}$ As mentioned before, an abrupt increase is observed in the absorption at $400 \mathrm{~nm}$ at the start of the reaction. This 'jump' is likely caused by a change in absorption spectrum when the chloride ions dissociate from the copper center. In other words, the change in absorption at $400 \mathrm{~nm}$ can be attributed to a change in the $\mathrm{Cu}^{\mathrm{II}} \leftarrow \mathrm{Cl}$ LMCT. This conclusion is in agreement with the absence of the 'jump' when the 3,5-DTBC oxidation is carried out in either the presence of an excess of chloride ions or the absence of chloride ions (Fig. S10 $\dagger$ ). It is clear that when chloride ions are not present in solution, the change in LMCT will not occur. In the presence of an excess of chloride ions, part of the copper centers dissociate from the ligand to form $\mathrm{CuCl}_{4}{ }^{2-}$ complex anions. Chloride dissociation is suppressed by the excess of chloride ions, resulting in the absence of an abrupt 'jump' in the absorption curve and leading to lower activity.

The catalytic system obtained with $\left[\mathrm{Cu}_{2}^{\mathrm{II}}\left(\mathbf{L}^{\mathbf{1}} \mathbf{S S L}^{\mathbf{1}}\right)\right.$ $\left.(\mathrm{Cl})_{2}\right]_{n}\left(\mathrm{BF}_{4}\right)_{2 n}$ shows the highest initial TOF with 4700 turnovers $\mathrm{h}^{-1}$ (entry 4). To acquire insight into the kinetics of the 3,5 -DTBC oxidation by $\left[\mathrm{Cu}_{2}^{\mathrm{II}}\left(\mathbf{L}^{\mathbf{1}}{ }^{*} \mathbf{S S L}^{\mathbf{1}}\right)(\mathrm{Cl})_{2}\right]_{n}\left(\mathrm{BF}_{4}\right)_{2 n}$ the substrate concentration was varied; the results of these experiments are shown in Fig. 7. The plot shows a first-order rate dependence on the substrate at lower 3,5-DTBC concentrations, but at higher concentrations the $\mathrm{Cu}^{\mathrm{II}}$ complex exhibits saturation. We have applied the Michaelis-Menten model to plot a Lineweaver-Burk graph (inset Fig. 7) from which the maximum rate $\left(V_{\max }=0.29 \mathrm{mM} \mathrm{s}^{-1}\right)$ and the MichaelisMenten constant $\left(K_{\mathrm{m}}=2.2 \mathrm{mM}\right)$ can be obtained. From these data the $k_{\text {cat }}$ is calculated to be $5200 \mathrm{~h}^{-1}$, which indicates that

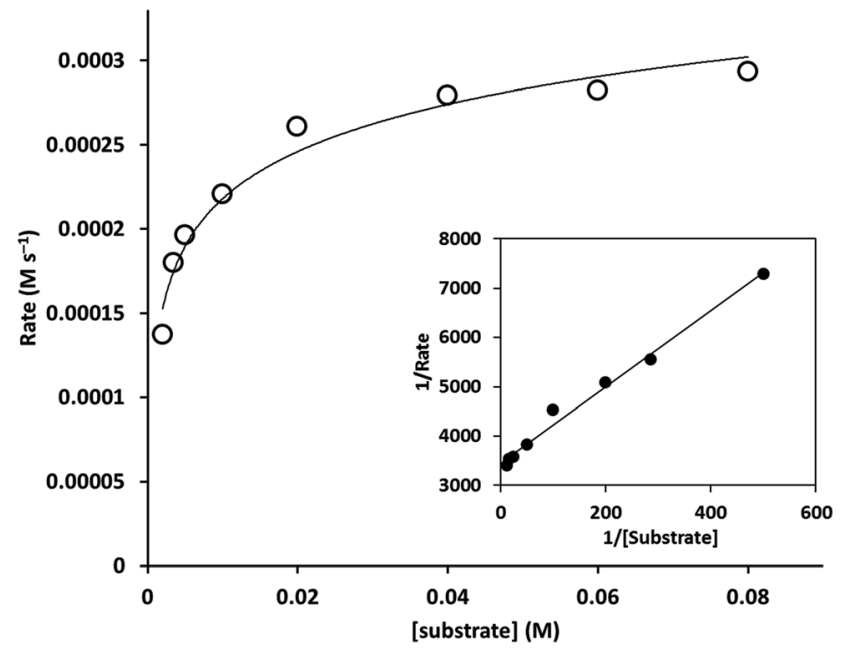

Fig. 7 A plot of the substrate concentration vs. the catalytic rate for $\left[\mathrm{Cu}_{2}^{\prime \prime}\left(\mathrm{L}^{1 *} \mathrm{SSL}^{1 *}\right)(\mathrm{Cl})_{2}\right]\left(\mathrm{BF}_{4}\right)_{2}$. The inset shows the Lineweaver-Burk plot. Reaction conditions: $0.4 \mathrm{mM}[\mathrm{Cu}], 20 \mathrm{mM} \mathrm{NEt}_{3}$ and varying amounts of $3,5-\mathrm{DTBC}$ in $3 \mathrm{~mL} \mathrm{CH} \mathrm{CH}_{3}$. $V_{\max }=0.29 \mathrm{mM} \mathrm{s}^{-1} ; K_{\mathrm{m}}=2.2 \mathrm{mM} ; k_{\text {cat }}=$ $5200 \mathrm{~h}^{-1}$

a small increase in initial TOF can be gained when the substrate concentration is increased $(3,5-\mathrm{DTBC} / \mathrm{Cu}>50)$. A comparable plot was obtained for the mononuclear complex $\left[\mathrm{Cu}^{\mathrm{II}}\left(\mathbf{L}^{\mathbf{1}} \mathbf{S C H}_{3}\right)(\mathrm{Cl})\right]\left(\mathrm{BF}_{4}\right)$, which showed similar behavior as $\left[\mathrm{Cu}_{2}^{\mathrm{II}}\left(\mathbf{L}^{\mathbf{1}^{*}} \mathbf{S S L}^{\mathbf{1}^{*}}\right)(\mathrm{Cl})_{2}\right]_{n}\left(\mathrm{BF}_{4}\right)_{2 n}$, but with a lower $V_{\max }(0.05 \mathrm{mM}$ $\mathrm{s}^{-1}$ ) and higher $K_{\mathrm{m}}$ value $(5.3 \mathrm{mM})$ (Fig. S12 $\dagger$ ). As it was found that the presence of chloride ions has a negative effect on the catalytic activity of the catalyst (Table 5), the concentration dependence of the catalytic system comprising $\mathbf{L}^{\mathbf{1}} \mathbf{S S S}^{\mathbf{1}}{ }^{*}$ in the absence of chlorides was also investigated. The compound $\left[\mathrm{Cu}_{2}^{\mathrm{II}}\left(\mathbf{L}^{\mathbf{1}^{*}} \mathbf{S S L}^{\mathbf{1}_{*}}\right)\right]\left(\mathrm{BF}_{4}\right)_{4}$ was formed in situ by adding two equivalents of $\left[\mathrm{Cu}^{\mathrm{II}}\left(\mathrm{H}_{2} \mathrm{O}\right)_{6}\right]\left(\mathrm{BF}_{4}\right)_{2}$ to $\mathbf{L}^{\mathbf{1}^{*}} \mathbf{S S L}^{\mathbf{1}^{*}}$ and removing most of the $\mathrm{H}_{2} \mathrm{O}$ with $\mathrm{Na}_{2} \mathrm{SO}_{4}$. The Lineweaver-Burk plot (Fig. S13 $\dagger$ ) for this catalyst shows a high $V_{\max }$ of $0.38 \mathrm{mM} \mathrm{s}^{-1}$ from which a $k_{\text {cat }}$ of $6900 \mathrm{~h}^{-1}$ can be calculated. At lower catalyst concentrations the catalyst seems to be rapidly deactivated (Fig. S11†).

\section{Discussion}

A large library of $\mathrm{Cu}^{\mathrm{II}}$ complexes has been synthesized and investigated for their catalytic activity in the oxidation of 3,5DTBC. Crystal structures of a number of the $\mathrm{Cu}^{\mathrm{II}}$ complexes of dinucleating ligands show that in these cases the chloride ions bridge between the $\mathrm{Cu}^{\mathrm{II}}$ centers of neighboring molecules, forming polymeric chains. The $\mathrm{Cu}^{\mathrm{II}}$ complexes with mononucleating ligands form dimeric species in some cases, depending on the coordination geometry of the copper ion. A squarepyramidal geometry of the copper center leaves the sixth coordination site open for coordination to the chloride ion of a molecule in a neighboring subunit.

The oxidation of 3,5-DTBC was carried out with different catalytic systems; three types of reactivity were observed with 
an increasing, decreasing or constant oxidation rate (Fig. 6). This variance in catalyst behavior indicates that depending on the ligand different activation mechanisms are operative in the formation of the active species. Catalytic systems that show development of the product following type A have the highest activity at the start of the experiment and become slower over time. For the less active catalytic systems, this type of behavior indicates catalyst degradation over time. However, for the faster catalytic systems like $\left[\mathrm{Cu}_{2}^{\mathrm{II}}\left(\mathbf{L}^{\mathbf{1}} \mathbf{S S L}^{\mathbf{1}}\right)\right]\left(\mathrm{BF}_{4}\right)_{4}$, the decrease in the catalytic rate may also be due to depletion of the substrate. The catalysts containing $\mathbf{L}^{1} \mathbf{O H}$ and $\mathbf{L}^{\mathbf{1}} \mathbf{N H}_{2}$ show constant activity during the entire experiment (type B), indicating that there is no deactivation of the catalyst. All the other catalysts show an induction period in their activity (type C), which indicates the presence of a pre-catalyst at the beginning of the reaction that is converted to the active catalyst (possibly a $\mathrm{Cu}^{\mathrm{II}}$ $\mu$-hydroxo species) later on. The ligands $\mathbf{L}^{\mathbf{1}} \mathbf{O H}$ and $\mathbf{L}^{\mathbf{1}} \mathbf{N H}_{\mathbf{2}}$ contain a proton donor/acceptor moiety, which might explain the absence of a similar induction period for these catalysts.

The presence of chloride ions has a negative effect on the catalytic activity. The chloride ions inhibit the reaction either by competing with the substrate for coordination sites or by formation of $\mathrm{CuCl}_{4}{ }^{2-}$, resulting in lower concentration of the active species in solution. The ease of formation of $\mathrm{CuCl}_{4}{ }^{2-}$ is demonstrated by the structure of the compound $\left[\mathrm{Cu}^{\mathrm{II}}\left(\mathbf{L}^{\mathbf{1}^{*}} \mathbf{S C H}_{3}\right)(\mathrm{Cl})\right]_{2}\left(\mathrm{CuCl}_{4}\right)$, which even formed in the presence of a substoichiometric amount of copper (Fig. S4 $\dagger$ ). Similar behavior was observed for $\mathbf{L}^{\mathbf{1}} \mathbf{S X S L} \mathbf{L}^{\mathbf{1}}{ }^{24}$

When comparing the catalytic rates of the different systems (Table 4), it is clear that many of the systems under study are not (much) more active than the blank system comprising copper salts in the absence of a ligand. The relative differences however, are very large. The mononuclear catalysts generally have a lower initial TOF than the catalysts with dinucleating ligands, which is not surprising considering that the reaction requires two electrons and that the active species has been proposed to be dinuclear. ${ }^{15}$ A number of the systems containing dinucleating ligands behave as mononuclear catalysts, because they are either too rigid $\left(\mathbf{L}^{1} \mathbf{S X S L} \mathbf{L}^{\mathbf{1}}\right.$ entry 10 , and $\mathbf{L}^{1} \mathbf{P h} \mathbf{L}^{\mathbf{1}}$ entry 13) or lack bridging sulfur donor atoms $\left(\mathbf{L}^{\mathbf{1}} \mathbf{C}_{\mathbf{6}} \mathbf{L}^{\mathbf{1}}\right.$ entry 12) and therefore exhibit lower TOFs. Several other of the dinucleating ligands strongly stabilize the $\mathrm{Cu}^{\mathrm{I}}$ oxidation state, and thus also result in low activity (entries 7, 9, 14 and 15). ${ }^{7,8}$ The catalytic systems with the highest activity are those containing ligands that stabilize $\mathrm{Cu}^{\mathrm{II}} \mu$-thiolate complexes $\left(\mathbf{L}^{\mathbf{1}} \mathbf{S S L}^{\mathbf{1}}, \mathbf{L}^{\mathbf{1}^{*}} \mathbf{S S L}^{\mathbf{1}^{*}}\right.$, $\left.\mathbf{L}^{2} \mathbf{S S L}^{2}, \mathbf{L}^{2} \mathbf{S S L}^{2 *}, \mathbf{L}^{4} \mathbf{S S L}^{\mathbf{4}}\right) .{ }^{4,7,8,35}$ The compound $\left[\mathrm{Cu}_{2}^{\mathrm{II}}\left(\mathbf{L}^{2} \mathbf{S S L}^{2}\right)-\right.$ $\left.(\mathrm{Cl})_{2}\right]_{n}\left(\mathrm{BF}_{4}\right)_{2 n}$ forms an exception with its relatively low activity, which can be explained by the fact that $\mathbf{L}^{2} \mathbf{S S L}^{2}$ in $\mathrm{CH}_{3} \mathrm{CN}$, the solvent used for catalysis, stabilizes a $\mathrm{Cu}^{\mathrm{I}}$ disulfide complex rather than a $\mathrm{Cu}^{\mathrm{II}} \mu$-thiolate complex. ${ }^{8}$ The $k_{\text {cat }}$ of $6900 \mathrm{~h}^{-1}$ observed for $\left[\mathrm{Cu}_{2}^{\mathrm{II}}\left(\mathbf{L}^{\mathbf{1}^{*}} \mathbf{S S L}^{\mathbf{1}^{*}}\right)\right]\left(\mathrm{BF}_{4}\right)_{4}$ is the second highest rate reported for 3,5-DTBC oxidation in $\mathrm{CH}_{3} \mathrm{CN}$ thus far. ${ }^{16,36}$

The existence of an equilibrium between dinuclear $\mathrm{Cu}^{\mathrm{I}}$ disulfide compounds and the redox isomeric dinuclear $\mathrm{Cu}^{\mathrm{II}}$ $\mu$-thiolate compounds has been shown to be strongly dependent on the redox potential of these compounds, as induced by the electronic and steric properties of the ligand system. ${ }^{24}$ Similarly, it may be argued that the high activity of the systems with $\mathrm{Cu}^{\mathrm{II}} \mu$-thiolate stabilizing ligands stems from the redox potential of the $\mathrm{Cu}^{\mathrm{I}}$ intermediate and the ability of these complexes to stabilize a $\mathrm{Cu}_{2}^{\mathrm{II}}\left(\mu-\eta^{2}: \eta^{2}\right.$-peroxide) species that is structurally as well as electronically similar to the $\mathrm{Cu}^{\mathrm{II}} \mu$-thiolate complex (Fig. 1). Stabilization of the $\mathrm{Cu}_{2}^{\mathrm{II}}\left(\mu-\eta^{2}: \eta^{2}\right.$-peroxide) species may be the prime reason for a faster reaction of the dinuclear $\mathrm{Cu}^{\mathrm{I}}$ intermediate with $\mathrm{O}_{2}$, thus resulting in efficient $\mathrm{Cu}^{\mathrm{I}}$ to $\mathrm{Cu}^{\mathrm{II}}$ reoxidation. As the reoxidation of the $\mathrm{Cu}^{\mathrm{I}}$ species has been proposed to be the rate-determining step of the reaction, this will thus result in an increase of the overall reaction rate. ${ }^{14,17,37}$ The activity of these catalytic systems can probably be increased even further by using a protic solvent like methanol, but this might also result in faster catalyst degradation. If via the redox equilibrium the $\mathrm{Cu}^{\mathrm{I}}$ disulfide intermediate is transformed to the corresponding $\mathrm{Cu}^{\mathrm{II}}$ thiolate species this will most likely lead to rapid catalyst deactivation, since $\mathrm{Cu}^{\mathrm{II}}$ $\mu$-thiolate complexes have been reported either to be oxidized to $\mathrm{Cu}^{\mathrm{II}}$ sulfinate and sulfonate complexes or to react with the substrate. ${ }^{19,38}$

\section{Conclusion}

$\mathrm{Cu}^{\mathrm{II}}$ complexes have been synthesized comprising either mononucleating or dinucleating ligands for the catalytic oxidation of 3,5-DTBC. Very high activity for the oxidation of 3,5DTBC is achieved using ligands that have the ability to form $\mathrm{Cu}^{\mathrm{II}} \mu$-thiolate complexes. The presence of chloride ions has a negative effect on the catalytic rates because of coordination to the active sites or the formation of $\mathrm{Cu}^{\mathrm{II}} \mathrm{Cl}_{4}{ }^{2-}$. The highest TOF reached is $6900 \mathrm{~h}^{-1}$ using $\left[\mathrm{Cu}_{2}^{\mathrm{II}}\left(\mathbf{L}^{\mathbf{1} *} \mathbf{S S L}^{\left.\mathbf{1}^{*}\right)}\right]\left(\mathrm{BF}_{4}\right)_{4}\right.$, which is one of the highest TOFs reported for 3,5-DTBC oxidation in $\mathrm{CH}_{3} \mathrm{CN}$ thus far. These results show that there are similarities between thiolato copper and (per)oxido copper chemistry and that ligands that stabilize $\mathrm{Cu}^{\mathrm{II}} \mu$-thiolate complexes might also induce the rapid formation of $\mathrm{Cu}_{2}^{\mathrm{II}}\left(\mu-\eta^{2}: \eta^{2}\right.$-peroxide) species.

\section{Experimental section}

\subsection{General methods}

Reagents and solvents were purchased from commercial sources. $\mathbf{L}^{1} \mathbf{S S L}^{1}, \mathbf{L}^{3} \mathbf{S S L}^{3}, \mathbf{L}^{5} \mathbf{S S L}^{5},{ }^{7} \mathbf{L}^{2} \mathbf{S S L}^{2}, \mathbf{L}^{4} \mathbf{S S L}^{4},{ }^{8} \mathbf{L}^{1 *} \mathbf{S S L}^{1 *}$,

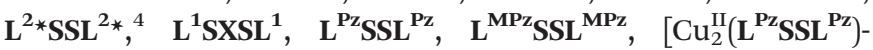
$\left.(\mathrm{Cl})_{2}\right]_{n}\left(\mathrm{BF}_{4}\right)_{2 n}, \quad\left[\mathrm{Cu}_{2}^{\mathrm{II}}\left(\mathbf{L}^{\mathbf{M P z}} \mathbf{S S L}^{\mathbf{M P z}}\right)(\mathrm{Cl})_{2}\right]_{n}\left(\mathrm{BF}_{4}\right)_{2 n},{ }^{24} \mathbf{L}^{\mathbf{1}} \mathbf{C}_{\mathbf{6}} \mathbf{L}^{\mathbf{1}},{ }^{20}$ $\mathbf{L}^{1} \mathbf{P h L}^{1},{ }^{21,22} \mathbf{P y}_{3} \mathbf{N},{ }^{23} \mathbf{L}^{\mathbf{1}} \mathbf{N H}_{2}{ }^{31}$ and 1,5-diamino-3-thiapentane dihydrobromide ${ }^{28}$ were synthesized according to literature procedures. NMR spectra were recorded on a Bruker 300 DPX spectrometer. IR spectra were obtained on a Perkin Elmer UATR (Single Reflection Diamond) Spectrum Two device (4000-700 $\mathrm{cm}^{-1}$; resolution $4 \mathrm{~cm}^{-1}$ ). Mass spectrometry was measured using a Finnigan Aqua Mass Spectrometer (MS) with electro spray ionization (ESI). Sample introduction was achieved through a Dionex ASI-100 automated sample injector 
with an eluent flow rate of $0.2 \mathrm{~mL} \mathrm{~min}^{-1}$. Elemental analyses were performed using a Perkin Elmer 2400 Series II CHNS/O analyzer or were performed by the Microanalytical laboratory Kolbe in Germany. UV-vis absorbance spectra were recorded on a Varian Cary50 spectrophotometer or using a transmission dip probe with variable path length on an Avantes Avaspec2048 spectrometer with Avalight-DH-S-BAL light source.

\subsection{X-ray crystallography}

$\left[\mathrm{Cu}_{2}{ }^{\mathrm{II}}\left(\mathbf{L}^{1} \mathbf{S L}^{1}\right)(\mathbf{C l})_{2}\right]_{n}\left(\mathrm{BF}_{4}\right)_{2 n}$ and $\left[\mathrm{Cu}^{\mathrm{II}}\left(\mathbf{L}^{1} \mathbf{N H}_{2}\right)(\mathbf{C l})\right]\left(\mathbf{B F}_{4}\right)$. The reflection intensities for $\left[\mathrm{Cu}_{2}^{\mathrm{II}}\left(\mathbf{L}^{\mathbf{1}} \mathbf{S L}^{\mathbf{1}}\right)(\mathrm{Cl})_{2}\right]_{n}\left(\mathrm{BF}_{4}\right)_{2 n}$ and $\left[\mathrm{Cu}^{\mathrm{II}}\left(\mathbf{L}^{\mathbf{1}} \mathbf{N H}_{2}\right)(\mathrm{Cl})\right]\left(\mathrm{BF}_{4}\right)$ were measured at $110(2) \mathrm{K}$ using a KM4/ Xcalibur (detector: Sapphire3) with enhanced graphite-monochromated Mo K $\alpha$ radiation $(\lambda=0.71073 \AA)$ under the program CrysAlisPro (Version 1.171.36.24 Agilent Technologies, 2012). The same program was used to refine the cell dimensions and for data reduction. The structures were solved with the program SHELXS-97/SHELXS-2013 (Sheldrick, 2008/2013) ${ }^{39}$ and was refined on $F^{2}$ with SHELXL-97/SHELXL-2013 (Sheldrick, 2008/2013). ${ }^{39}$ Analytical numeric absorption corrections based on a multifaceted crystal model were applied using CrysAlisPro. The temperature of the data collection was controlled using the system Cryojet (manufactured by Oxford Instruments). The $\mathrm{H}$ atoms were placed at calculated positions using the instructions AFIX 23, AFIX 43 or AFIX 137 with isotropic displacement parameters having values 1.2 or 1.5 times $U_{\text {eq }}$ of the attached $\mathrm{C}$ atoms. The $\mathrm{H}$ atoms attached to $\mathrm{N} 2$ for $\left[\mathrm{Cu}^{\mathrm{II}}\left(\mathbf{L}^{\mathbf{1}} \mathbf{N H}_{2}\right)(\mathrm{Cl})\right]\left(\mathrm{BF}_{4}\right)$ were found from difference Fourier map, and their coordinates and isotropic temperature factors were refined freely. CCDC 1043171 and 1043165 contain the supplementary crystallographic data for $\left[\mathrm{Cu}_{2}^{\mathrm{II}}\left(\mathbf{L}^{\mathbf{1}} \mathbf{S L}^{\mathbf{1}}\right)\right.$ $\left.(\mathrm{Cl})_{2}\right]_{n}\left(\mathrm{BF}_{4}\right)_{2 n}$ and $\left[\mathrm{Cu}^{\mathrm{II}}\left(\mathbf{L}^{\mathbf{1}} \mathbf{N H}_{2}\right)(\mathrm{Cl})\right]\left(\mathrm{BF}_{4}\right)$.

$\left[\mathrm{Cu}^{\mathrm{II}}\left(\mathrm{L}^{1} \mathrm{SCH}_{3}\right)(\mathbf{C l})\right]\left(\mathrm{BF}_{4}\right)$ and $\left[\mathrm{Cu}^{\mathrm{II}}\left(\mathbf{L}^{3} \mathbf{S C H}_{3}\right)(\mathbf{C l})\right]\left(\mathrm{BF}_{4}\right)$. The reflection intensities for $\left[\mathrm{Cu}^{\mathrm{II}}\left(\mathbf{L}^{\mathbf{1}} \mathbf{S} \mathbf{C} \mathbf{H}_{3}\right)(\mathrm{Cl})\right]\left(\mathrm{BF}_{4}\right)$ and $\left[\mathrm{Cu}^{\mathrm{II}}\left(\mathbf{L}^{3} \mathbf{S C H}_{3}\right)(\mathrm{Cl})\right]\left(\mathrm{BF}_{4}\right)$ were measured at $110(2) \mathrm{K}$ using a SuperNova diffractometer (equipped with Atlas detector) with Mo K $\alpha$ radiation $(\lambda=0.71073 \AA)$ for $\left[\mathrm{Cu}^{\mathrm{II}}\left(\mathbf{L}^{\mathbf{1}} \mathbf{S C H}_{3}\right)(\mathrm{Cl})\right]\left(\mathrm{BF}_{4}\right)$ and $\mathrm{Cu} \mathrm{K} \alpha$ radiation $(\lambda=1.54178 \AA)$ for $\left[\mathrm{Cu}^{\mathrm{II}}\left(\mathbf{L}^{3} \mathbf{S C H} \mathbf{H}_{3}\right)(\mathrm{Cl})\right]\left(\mathrm{BF}_{4}\right)$ under the program CrysAlisPro (Version 1.171.36.32 Agilent Technologies, 2013). The same program was used to refine the cell dimensions and for data reduction. The structures were solved with the program SHELXS-2013 (Sheldrick, 2013) ${ }^{39}$ and were refined on $F^{2}$ with SHELXL-2013 (Sheldrick, 2013). ${ }^{39}$ Analytical numeric absorption corrections based on a multifaceted crystal model were applied using CrysAlisPro. The temperature of the data collection was controlled using the system Cryojet (manufactured by Oxford Instruments). The $\mathrm{H}$ atoms were placed at calculated positions using the instructions AFIX 23, AFIX 43 or AFIX 137 with isotropic displacement parameters having values 1.2 or 1.5 times $U_{\text {eq }}$ of the attached $\mathrm{C}$ atoms. CCDC 1043166 and 1043170 contain the supplementary crystallographic data for $\left[\mathrm{Cu}^{\mathrm{II}}\left(\mathbf{L}^{\mathbf{1}} \mathbf{S C H}_{3}\right)(\mathrm{Cl})\right]\left(\mathrm{BF}_{4}\right)$ and $\left[\mathrm{Cu}^{\mathrm{II}}\left(\mathbf{L}^{3} \mathbf{S C H}_{3}\right)(\mathrm{Cl})\right]\left(\mathrm{BF}_{4}\right)$.

$\left[\mathbf{C u}_{2}^{\text {II }}\left(\mathbf{L}^{1} \mathbf{C}_{6} \mathbf{L}^{\mathbf{1}}\right)(\mathbf{C l})_{2}\right]_{n}\left(\mathbf{B F}_{4}\right)_{2 n}$. The reflection intensities for $\left[\mathrm{Cu}_{2}^{\mathrm{II}}\left(\mathbf{L}^{\mathbf{1}} \mathbf{C}_{6} \mathbf{L}^{\mathbf{1}}\right)(\mathrm{Cl})_{2}\right]_{n}\left(\mathrm{BF}_{4}\right)_{2 n}$ were measured on a Bruker Kappa ApexII diffractometer with sealed tube and Triumph mono- chromator $(\lambda=0.71073 \AA)$ up to a resolution of $(\sin \theta / \lambda)_{\max }=$ $0.57 \AA^{-1}$. The crystal consisted of several fragments. The four major fragments were taken into account during the integration with the Eval14 software. ${ }^{40}$ The second fragment has an arbitrary orientation with respect to the first. The third fragment is generated by a twofold rotation about $h k l=(1,0,0)$ from the first. The fourth fragment has the same twin relation to the second. An absorption correction based on multiple measured reflections was performed with TWINABS (0.57-0.75 correction range). ${ }^{41}$ The structure was solved with Direct Methods using SHELXS-97 and refined with SHELXL-97 against $F^{2}$ of all reflections. ${ }^{39}$ The presence of four fragments was handled with a HKLF-5 reflection file. ${ }^{42}$ The twin fractions refined to $0.342(15), 0.267(7)$, and $0.083(4)$. Non-hydrogen atoms were refined freely with anisotropic displacement parameters. Hydrogen atoms were introduced in calculated positions and refined with a riding model. The $\mathrm{BF}_{4}^{-}$anion was refined with a disorder model of two orientations. Geometry calculations and checking for higher symmetry was performed with the PLATON program. ${ }^{43}$ CCDC 1042477 contains the supplementary crystallographic data for $\left[\mathrm{Cu}_{2}^{\mathrm{II}}\left(\mathbf{L}^{\mathbf{1}} \mathbf{C}_{6} \mathbf{L}^{\mathbf{1}}\right)(\mathrm{Cl})_{2}\right]_{n}\left(\mathrm{BF}_{4}\right)_{2 n}$.

\subsection{Ligand synthesis}

Bis-1,5-((2-pyridylmethyl)amino)ethyl-3-thiapentane ( $\left.\mathbf{L}^{1} \mathrm{SL}^{1}\right)$. 1,5Diamino-3-thiapentane dihydrobromide (1.43 g, $5.1 \mathrm{mmol})$ was dissolved in methanol $(40 \mathrm{~mL})$. To this solution 2-pyridinecarboxaldehyde $(1.9 \mathrm{~mL}, 20.3 \mathrm{mmol})$ was added, after which the reaction mixture was cooled to $0{ }^{\circ} \mathrm{C}$. $\mathrm{NaBH}_{3} \mathrm{CN}(1.28 \mathrm{~g}$, $20.3 \mathrm{mmol}$ ) was added in small portions. The reaction mixture was allowed to warm up to RT and was stirred for 3 days. The reaction mixture was quenched by addition of $\mathrm{HCl}(37 \%)$ until $\mathrm{pH}=1$. After evaporation of the solvent, the product was treated with $\mathrm{NaOH}(50 \mathrm{~mL} ; 5 \mathrm{M})$ and the aqueous layer was extracted with $\mathrm{CHCl}_{3}(3 \times 25 \mathrm{~mL})$. The organic fractions were combined, dried over $\mathrm{MgSO}_{4}$ and evaporated to dryness yielding $\mathbf{L}^{1} \mathbf{S L}^{1}$ as a brown oil (1.68 g, $\left.3.5 \mathrm{mmol}, 68 \%\right) .{ }^{1} \mathrm{H}$ NMR (300 MHz, $\left.\mathrm{CD}_{3} \mathrm{OD}, \mathrm{RT}\right): \delta 2.64\left(\mathrm{~m}, 8 \mathrm{H}, \mathrm{S}-\mathrm{CH}_{2}-\mathrm{CH}_{2}\right), 3.76$ (s, 8H, Py- $\left.\mathrm{CH}_{2}-\mathrm{N}\right), 7.21\left(\mathrm{~m}, 4 \mathrm{H}, \mathrm{Py}-H_{5}\right), 7.62(\mathrm{~d}, J=8 \mathrm{~Hz}, 4 \mathrm{H}$, $\left.\mathrm{Py}-H_{3}\right), 7.72\left(\mathrm{dt}, J=8 \mathrm{~Hz}, 2 \mathrm{~Hz}, 4 \mathrm{H}, \mathrm{Py}-H_{4}\right), 8.41(\mathrm{~m}, 4 \mathrm{H}$, $\left.\mathrm{Py}-\mathrm{H}_{6}\right) \cdot{ }^{13} \mathrm{C} \mathrm{NMR}\left(75 \mathrm{MHz}, \mathrm{CD}_{3} \mathrm{OD}, \mathrm{RT}\right): \delta 30.5\left(\mathrm{~S}-\mathrm{CH}_{2}-\mathrm{CH}_{2}\right)$, $55.1\left(\mathrm{~S}-\mathrm{CH}_{2}-\mathrm{CH}_{2}\right), 60.7\left(\mathrm{Py}-\mathrm{CH}_{2}-\mathrm{N}\right), 123.6\left(\mathrm{Py}-\mathrm{C}_{5}\right), 124.6$ $\left(\mathrm{Py}-C_{3}\right), 138.4\left(\mathrm{Py}-C_{4}\right), 149.3\left(\mathrm{Py}-\mathrm{C}_{6}\right), 160.4\left(\mathrm{Py}-C_{2}\right)$. ESI-MS found (calculated) for $[\mathrm{M}+\mathrm{H}]^{+} \mathrm{m} / \mathrm{z} 485.1$ (485.3); $[\mathrm{M}+\mathrm{Na}]^{+} \mathrm{m} / \mathrm{z}$ 507.1 (507.2). IR (neat, $\mathrm{cm}^{-1}$ ): 3050w, 2924w, 2821m, 1589s, $1569 \mathrm{~m}, 1473 \mathrm{~m}, 1432 \mathrm{~s}, 1362 \mathrm{~m}, 1265 \mathrm{w}, 1147 \mathrm{~m}, 1117 \mathrm{~m}, 1086 \mathrm{~m}$, $1047 \mathrm{~m}, 994 \mathrm{~m}, 978 \mathrm{~m}, 895 \mathrm{w}, 755 \mathrm{vs}, 731 \mathrm{vs}, 701 \mathrm{~m}, 613 \mathrm{~m}, 465 \mathrm{w}$.

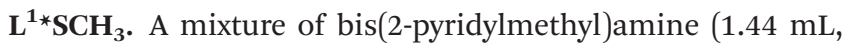
$8.0 \mathrm{mmol})$ and propylene sulfide $(0.94 \mathrm{~mL}, 12.0 \mathrm{mmol})$ was stirred in $20 \mathrm{~mL} \mathrm{CH}{ }_{3} \mathrm{CN}$ at reflux temperature for $18 \mathrm{~h}$ under Ar atmosphere. The solvent was evaporated, after which the resulting oil was dissolved in $20 \mathrm{~mL}$ tetrahydrofuran. $\mathrm{NaH}$ ( $0.37 \mathrm{~g}, 9.3 \mathrm{mmol}, 60 \%$ in mineral oil) was added and the reaction mixture was stirred for $2 \mathrm{~h}$. To this pink reaction mixture, MeI (0.51 mL, $8.2 \mathrm{mmol})$ was added and all was stirred for $5 \mathrm{~h}$. The reaction was quenched by dropwise addition of $\mathrm{H}_{2} \mathrm{O}$. In total $40 \mathrm{~mL} \mathrm{H} \mathrm{H}_{2} \mathrm{O}$ was added after which the water layer was 
extracted with $\mathrm{CH}_{2} \mathrm{Cl}_{2}(3 \times 30 \mathrm{~mL})$. The combined organic layers were dried over $\mathrm{Na}_{2} \mathrm{SO}_{4}$. The crude product was purified by column chromatography over basic alumina (50/50 EtOAc/ petroleum ether) to yield $\mathbf{L}^{\mathbf{1}^{*} \mathbf{S} \mathbf{S H}_{3}}$ as a light yellow oil (1.98 g, $6.9 \mathrm{mmol}, 86 \%) .{ }^{1} \mathrm{H}$ NMR (300 $\left.\mathrm{MHz}, \mathrm{CD}_{3} \mathrm{OD}, \mathrm{RT}\right): \delta 1.18$ $\left(\mathrm{s}, 1.5 \mathrm{H}, \mathrm{C}^{*}-\mathrm{CH}_{3}\right), 1.20\left(\mathrm{~s}, 1.5 \mathrm{H}, \mathrm{C}^{*}-\mathrm{CH}_{3}\right), 1.99\left(\mathrm{~s}, 3 \mathrm{H}, \mathrm{S}-\mathrm{CH}_{3}\right)$, 2.52 (dd, $J=13 \mathrm{~Hz}, 8 \mathrm{~Hz}, 1 \mathrm{H}, \mathrm{N}-\mathrm{CH}_{2}-\mathrm{C}^{*}$ ), 2.68 (dd, $J=13 \mathrm{~Hz}, 7$ $\left.\mathrm{Hz}, 1 \mathrm{H}, \mathrm{N}-\mathrm{CH}_{2}-\mathrm{C}^{*}\right), 2.86\left(\mathrm{dt}, J=8 \mathrm{~Hz}, 7 \mathrm{~Hz}, 1 \mathrm{H}, \mathrm{C}^{*}-H\right), 3.81$ (s, $4 \mathrm{H}, \mathrm{Py}-\mathrm{CH}_{2}-\mathrm{N}$ ), 7.30 (ddd, $J=7 \mathrm{~Hz}, 5 \mathrm{~Hz}, 1 \mathrm{~Hz}, 2 \mathrm{H}, \mathrm{Py}-\mathrm{H}_{5}$ ), $7.71\left(\mathrm{~d}, J=8 \mathrm{~Hz}, 2 \mathrm{H}, \mathrm{Py}-H_{3}\right), 7.82(\mathrm{td}, J=8 \mathrm{~Hz}, 2 \mathrm{~Hz}, 2 \mathrm{H}$, Py $-H_{4}$ ), 8.43 (ddd, $\left.J=5 \mathrm{~Hz}, 2 \mathrm{~Hz}, 1 \mathrm{~Hz}, 2 \mathrm{H}, \mathrm{Py}-H_{6}\right) .{ }^{13} \mathrm{C} \mathrm{NMR}$ (75 MHz, $\left.\mathrm{CD}_{3} \mathrm{OD}, \mathrm{RT}\right): \delta 13.0\left(\mathrm{~S}-\mathrm{CH}_{3}\right), 19.5\left(\mathrm{C}^{*}-\mathrm{CH}_{3}\right), 40.3\left(C^{*}\right)$, $61.4\left(\mathrm{~N}-\mathrm{CH}_{2}-\mathrm{C}^{*}\right), 61.5\left(\mathrm{Py}-\mathrm{CH}_{2}-\mathrm{N}\right), 123.8\left(\mathrm{Py}-\mathrm{C}_{5}\right), 125.1$ $\left(\mathrm{Py}-C_{3}\right), 138.5\left(\mathrm{Py}-C_{4}\right), 149.3\left(\mathrm{Py}-C_{6}\right), 160.5\left(\mathrm{Py}-C_{2}\right)$. ESI-MS found (calculated) for $[\mathrm{M}+\mathrm{H}]^{+} \mathrm{m} / z 288.1$ (288.2). IR (neat, $\mathrm{cm}^{-1}$ ): 3392br, 2961w, 2919m, 2822w, 1663w, 1589s, 1569m, $1473 \mathrm{~m}, 1432 \mathrm{~s}, 1365 \mathrm{~m}, 1300 \mathrm{w}, 1247 \mathrm{w}, 1148 \mathrm{~m}, 1125 \mathrm{w}, 1075 \mathrm{~m}$, $1047 \mathrm{~m}, 995 \mathrm{~m}, 981 \mathrm{~m}, 957 \mathrm{~m}, 759 \mathrm{vs}, 613 \mathrm{~m}, 525 \mathrm{~m}, 460 \mathrm{~m}$.

$\mathrm{N}$-((6-Methylpyridin-2-yl)methyl)-2-(methylthio)ethylamine. 2-(Methylthio)ethylamine $(1.00 \mathrm{~g}, 11.0 \mathrm{mmol})$ and 6-methylpyridine-2-carboxaldehyde (1.34 g, $11.0 \mathrm{mmol})$ were dissolved in $35 \mathrm{~mL}$ methanol and stirred at reflux temperature for $24 \mathrm{~h}$. The dark orange solution was cooled to RT, after which $\mathrm{NaBH}_{4}$ $(0.64 \mathrm{~g}, 16.9 \mathrm{mmol})$ was added and the reaction mixture was stirred for $3 \mathrm{~h}$. The solvent was evaporated and $30 \mathrm{~mL} \mathrm{H}_{2} \mathrm{O}$ and $30 \mathrm{~mL} \mathrm{CH} \mathrm{Cl}_{2} \mathrm{Cl}_{2}$ were added. The layers were separated and the aqueous layer was extracted $\mathrm{CH}_{2} \mathrm{Cl}_{2}(2 \times 30 \mathrm{~mL})$. The combined organic layers were dried over $\mathrm{Na}_{2} \mathrm{SO}_{4}$ and the solvent was evaporated to yield $N$-((6-methylpyridin-2-yl)methyl)-2-(methylthio)ethylamine in quantitative yield as a red/brown oil. ${ }^{1} \mathrm{H}$ NMR (300 MHz, CD 3 OD, RT): $\delta 2.04$ (s, 3H, S-CH $), 2.52$ $\left(\mathrm{s}, 3 \mathrm{H}, \mathrm{Py}-\mathrm{CH}_{3}\right), 2.65\left(\mathrm{~m}, 2 \mathrm{H}, \mathrm{S}-\mathrm{CH}_{2}-\mathrm{CH}_{2}\right), 2.79(\mathrm{~m}, 2 \mathrm{H}$, $\mathrm{S}-\mathrm{CH}_{2}-\mathrm{CH}_{2}$ ), 3.85 (s, 2H, Py-CH $\left.-\mathrm{N}\right), 7.14(\mathrm{~d}, J=8 \mathrm{~Hz}, 1 \mathrm{H}$, $\left.\mathrm{Py}-H_{3}\right), 7.23$ (d, $\left.J=8 \mathrm{~Hz}, 1 \mathrm{H}, \mathrm{Py}-H_{5}\right), 7.66(\mathrm{t}, J=8 \mathrm{~Hz}, 1 \mathrm{H}$, $\left.\mathrm{Py}-\mathrm{H}_{4}\right) .{ }^{13} \mathrm{C}$ NMR (75 MHz, $\left.\mathrm{CD}_{3} \mathrm{OD}, \mathrm{RT}\right): \delta 15.1\left(\mathrm{~S}-\mathrm{CH}_{3}\right), 24.1$ $\left(\mathrm{Py}-\mathrm{CH}_{3}\right), 34.5\left(\mathrm{~S}-\mathrm{CH}_{2}-\mathrm{CH}_{2}\right), 48.1\left(\mathrm{~S}-\mathrm{CH}_{2}-\mathrm{CH}_{2}\right), 54.8\left(\mathrm{Py}-\mathrm{CH}_{2}-\mathrm{N}\right)$, $120.9\left(\mathrm{Py}-C_{5}\right), 123.1\left(\mathrm{Py}-C_{3}\right), 138.7\left(\mathrm{Py}-C_{4}\right), 159.0\left(\mathrm{Py}-C_{6}\right)$, $159.5\left(\mathrm{Py}-C_{2}\right)$.

$\mathbf{L}^{2} \mathbf{S C H}_{3}$. N-((6-Methylpyridin-2-yl)methyl)-2-(methylthio)ethylamine $(1.28 \mathrm{~g}, 6.5 \mathrm{mmol})$ and 2-pyridinecarboxaldehyde (0.62 $\mathrm{mL}, 6.5 \mathrm{mmol}$ ) were dissolved in $20 \mathrm{~mL}$ methanol and stirred at reflux temperature for $2 \mathrm{~h}$. The dark brown solution was cooled to RT, $\mathrm{NaBH}_{4}(0.39 \mathrm{~g}, 10.4 \mathrm{mmol})$ was added and the reaction mixture was stirred for $3 \mathrm{~h}$. The solvent was evaporated and $20 \mathrm{~mL} \mathrm{H}_{2} \mathrm{O}$ and $20 \mathrm{~mL} \mathrm{CH}_{2} \mathrm{Cl}_{2}$ was added. The layers were separated and the aqueous layer was extracted with $\mathrm{CH}_{2} \mathrm{Cl}_{2}(2 \times 20 \mathrm{~mL})$. The combined organic layers were dried over $\mathrm{Na}_{2} \mathrm{SO}_{4}$ and the solvent was evaporated to yield a brown oil ( $1.84 \mathrm{~g})$. The compound was purified by column chromatography over basic alumina (30/70 EtOAc/petroleum ether) to yield $\mathbf{L}^{2} \mathbf{S C H}_{3}$ as a yellow/orange oil (0.93 g, $\left.3.2 \mathrm{mmol}, 50 \%\right)$. ${ }^{1} \mathrm{H}$ NMR (300 MHz, CD 3 OD, RT): $\delta 1.59$ (s, 3H, S-CH C $_{3}, 2.47$ (s, 3H, $\left.\mathrm{Py}_{\mathrm{Me}}-\mathrm{CH}_{3}\right), 2.64\left(\mathrm{~m}, 2 \mathrm{H}, \mathrm{S}-\mathrm{CH}_{2}-\mathrm{CH}_{2}\right), 2.75(\mathrm{~m}, 2 \mathrm{H}$, $\left.\mathrm{S}-\mathrm{CH}_{2}-\mathrm{CH}_{2}\right), 3.79\left(\mathrm{~s}, 2 \mathrm{H}, \mathrm{Py}-\mathrm{CH}_{2}-\mathrm{N}\right), 3.82\left(\mathrm{~s}, 2 \mathrm{H}, \mathrm{Py}-\mathrm{CH}_{2}-\mathrm{N}\right)$, 7.09 (d, $\left.J=8 \mathrm{~Hz}, 1 \mathrm{H}, \mathrm{Py}_{\mathrm{Me}}-H_{3}\right), 7.24(\mathrm{ddd}, J=7 \mathrm{~Hz}, 5 \mathrm{~Hz}, 1 \mathrm{~Hz}$, $1 \mathrm{H}, \mathrm{Py}_{\mathrm{Me}}-H_{5}$ ), 7.47 (d, $\left.J=8 \mathrm{~Hz}, 1 \mathrm{H}, \mathrm{Py}-H_{3}\right), 7.65\left(\mathrm{~m}, 2 \mathrm{H}, \mathrm{Py}-H_{4}\right.$;
$\left.\mathrm{Py}_{\mathrm{Me}}-H_{4}\right), 7.77\left(\mathrm{td}, J=8 \mathrm{~Hz}, 2 \mathrm{~Hz}, 1 \mathrm{H}, \mathrm{Py}-H_{5}\right), 8.42(\mathrm{~d}, J=5 \mathrm{~Hz}$, $\left.1 \mathrm{H}, \mathrm{Py}-\mathrm{H}_{6}\right) .{ }^{13} \mathrm{C} \mathrm{NMR}\left(75 \mathrm{MHz}, \mathrm{CD}_{3} \mathrm{OD}, \mathrm{RT}\right): \delta 15.6\left(\mathrm{~S}-\mathrm{CH}_{3}\right)$, $23.9\left(\mathrm{Py}-\mathrm{CH}_{3}\right), 32.5\left(\mathrm{~S}-\mathrm{CH}_{2}-\mathrm{CH}_{2}\right), 54.7\left(\mathrm{~S}-\mathrm{CH}_{2}-\mathrm{CH}_{2}\right), 60.8$ $\left(\mathrm{Py}-\mathrm{CH}_{2}-\mathrm{N}\right), 60.8\left(\mathrm{Py}-\mathrm{CH}_{2}-\mathrm{N}\right), 121.6\left(\mathrm{Py}_{\mathrm{Me}}-C_{5}\right), 123.1\left(\mathrm{Py}_{\mathrm{Me}}-C_{3}\right)$, $123.7\left(\mathrm{Py}-C_{5}\right), 124.8\left(\mathrm{Py}-C_{3}\right), 138.5\left(\mathrm{Py}_{\mathrm{Me}}-C_{4}\right), 138.7\left(\mathrm{Py}-C_{4}\right)$, $149.3\left(\mathrm{Py}-C_{6}\right), 158.5\left(\mathrm{Py}_{\mathrm{Me}}-C_{2}\right), 159.9\left(\mathrm{Py}_{\mathrm{Me}}-C_{6}\right), 160.6\left(\mathrm{Py}-C_{2}\right)$. ESI-MS found (calculated) for $[\mathrm{M}+\mathrm{H}]^{+} \mathrm{m} / z 288.1$ (288.2). IR (neat, $\mathrm{cm}^{-1}$ ): 3393w, 3061w, 2916m, 2828m, 1591s, 1577s, $1456 \mathrm{~s}, 1433 \mathrm{~s}, 1363 \mathrm{~m}, 1290 \mathrm{w}, 1152 \mathrm{~m}, 1118 \mathrm{~m}, 1089 \mathrm{~m}, 1047 \mathrm{~m}$, 994m, 783s, 756vs, 614m, 545m.

$\mathbf{L}^{3} \mathbf{S C H}_{3}$. N-((6-Methylpyridin-2-yl)methyl)-2-(methylthio)ethylamine (1.28 g, $6.5 \mathrm{mmol})$ and 6-methylpyridine-2-carboxaldehyde $(0.79 \mathrm{~g}, 6.5 \mathrm{mmol})$ were dissolved in $20 \mathrm{~mL}$ methanol and stirred at reflux temperature for $18 \mathrm{~h}$. The brown solution was cooled to RT and $\mathrm{NaBH}_{4}(0.37 \mathrm{~g}, 9.8 \mathrm{mmol})$ was added and the reaction mixture was stirred for $2 \mathrm{~h}$. The solvent was evaporated and $20 \mathrm{~mL} \mathrm{H} \mathrm{H}_{2} \mathrm{O}$ and $20 \mathrm{~mL} \mathrm{CH}_{2} \mathrm{Cl}_{2}$ were added. The layers were separated and the aqueous layer was extracted two more times with $20 \mathrm{~mL} \mathrm{CH} \mathrm{Cl}_{2}$. The combined organic layers were dried over $\mathrm{Na}_{2} \mathrm{SO}_{4}$ and the solvent was evaporated to yield a brown oil (1.93 g). The compound was purified by column chromatography over basic alumina (30/70 EtOAc/petroleum ether) to yield $\mathbf{L}^{3} \mathbf{S C H}_{3}$ as a yellow/orange oil (0.91 g, $3.0 \mathrm{mmol}$, 46\%). ${ }^{1} \mathrm{H}$ NMR (300 MHz, $\left.\mathrm{CD}_{3} \mathrm{OD}, \mathrm{RT}\right): \delta 1.95$ (s, 3H, S-CH $\mathrm{CH}_{3}$, 2.47 (s, 6H, Py- $\left.\mathrm{CH}_{3}\right), 2.64\left(\mathrm{~m}, 2 \mathrm{H}, \mathrm{S}-\mathrm{CH}_{2}-\mathrm{CH}_{2}\right), 2.74(\mathrm{~m}, 2 \mathrm{H}$, $\mathrm{S}-\mathrm{CH}_{2}-\mathrm{CH}_{2}$ ), 3.78 (s, 4H, Py- $\left.\mathrm{CH}_{2}-\mathrm{N}\right), 7.08$ (d, $J=8 \mathrm{~Hz}, 2 \mathrm{H}$, $\left.\mathrm{Py}-H_{3}\right), 7.47$ (d, $\left.J=8 \mathrm{~Hz}, 2 \mathrm{H}, \mathrm{Py}-H_{5}\right), 7.63(\mathrm{t}, J=8 \mathrm{~Hz}, 2 \mathrm{H}$, $\left.\mathrm{Py}-\mathrm{H}_{4}\right) .{ }^{13} \mathrm{C} \mathrm{NMR}\left(75 \mathrm{MHz}, \mathrm{CD}_{3} \mathrm{OD}, \mathrm{RT}\right): \delta 15.6\left(\mathrm{~S}-\mathrm{CH}_{3}\right), 23.9$ $\left(\mathrm{Py}-\mathrm{CH}_{3}\right), 32.6\left(\mathrm{~S}-\mathrm{CH}_{2}-\mathrm{CH}_{2}\right), 54.7\left(\mathrm{~S}-\mathrm{CH}_{2}-\mathrm{CH}_{2}\right), 60.8\left(\mathrm{Py}-\mathrm{CH}_{2}-\mathrm{N}\right)$, $121.5\left(\mathrm{Py}-C_{5}\right), 123.1\left(\mathrm{Py}-C_{3}\right), 138.7\left(\mathrm{Py}-C_{4}\right), 158.5\left(\mathrm{Py}-C_{6}\right), 160.1$ $\left(\mathrm{Py}-C_{2}\right)$. ESI-MS found (calculated) for $[\mathrm{M}+\mathrm{H}]^{+} \mathrm{m} / z \quad 302.1$ (302.2). IR (neat, $\mathrm{cm}^{-1}$ ): 3388w, 3061w, 2917m, 2829w, 1592s, $1577 \mathrm{~s}, 1456 \mathrm{~s}, 1375 \mathrm{~m}, 1355 \mathrm{~m}, 1291 \mathrm{w}, 1154 \mathrm{~m}, 1117 \mathrm{~m}, 1090 \mathrm{~m}$, $1035 \mathrm{~m}, 994 \mathrm{~m}, 972 \mathrm{~m}, 786 \mathrm{~s}, 760 \mathrm{~m}, 627 \mathrm{~m}, 546 \mathrm{~m}$.

$\mathbf{L}^{\mathbf{1}} \mathbf{O H}$. This ligand was synthesized using a modified literature procedure. ${ }^{23,26}$ 2-Pyridinecarboxaldehyde $(1.90 \mathrm{~mL}$, $20.0 \mathrm{mmol})$ was added to ethanolamine $(0.60 \mathrm{~mL}, 10.0 \mathrm{mmol})$ dissolved in $30 \mathrm{~mL} \mathrm{CH} \mathrm{Cl}_{2}$. $\mathrm{NaBH}(\mathrm{OAc})_{3}(6.0 \mathrm{~g}, 28.3 \mathrm{mmol})$ was added in portions over $15 \mathrm{~min}$. after which the reaction mixture was stirred for $4 \mathrm{~h}$. The reaction was quenched by addition of $40 \mathrm{~mL} \mathrm{NaHCO}_{3}$ (sat.). The layers were separated and the aqueous layer was extracted two more times with $20 \mathrm{~mL} \mathrm{CH}_{2} \mathrm{Cl}_{2}$. The combined organic layers were dried over $\mathrm{Na}_{2} \mathrm{SO}_{4}$ and then evaporated to dryness yielding $\mathbf{L}^{1} \mathbf{O H}$ as a yellow oil. (2.41 g, $9.9 \mathrm{mmol}, 99 \%) .{ }^{1} \mathrm{H}$ NMR $(300 \mathrm{MHz}$, $\left.\mathrm{CD}_{3} \mathrm{CN}, \mathrm{RT}\right): \delta 2.71\left(\mathrm{t}, J=6 \mathrm{~Hz}, 2 \mathrm{H}, \mathrm{S}-\mathrm{CH}_{2}-\mathrm{CH}_{2}\right), 3.56(\mathrm{t}, J=$ $\left.6 \mathrm{~Hz}, 2 \mathrm{H}, \mathrm{S}-\mathrm{CH}_{2}-\mathrm{CH}_{2}\right), 3.83\left(\mathrm{~s}, 4 \mathrm{H}, \mathrm{Py}-\mathrm{CH}_{2}-\mathrm{N}\right), 4.0$ (br, $\mathrm{CH}_{2}-\mathrm{OH}$ ), 7.17 (m, 2H, Py- $\left.H_{5}\right), 7.43$ (d, $J=8 \mathrm{~Hz}, 2 \mathrm{H}, \mathrm{Py}-H_{3}$ ), $7.66\left(\mathrm{td}, J=8 \mathrm{~Hz}, 2 \mathrm{~Hz}, 2 \mathrm{H}, \mathrm{Py}-H_{4}\right), 8.47(\mathrm{~d}, J=5 \mathrm{~Hz}, 2 \mathrm{H}$, $\left.\mathrm{Py}-\mathrm{H}_{6}\right) .{ }^{13} \mathrm{C} \mathrm{NMR}\left(75 \mathrm{MHz}, \mathrm{CD}_{3} \mathrm{CN}, \mathrm{RT}\right): \delta 57.5\left(\mathrm{~S}-\mathrm{CH}_{2}-\mathrm{CH}_{2}\right)$, $60.3\left(\mathrm{~S}-\mathrm{CH}_{2}-\mathrm{CH}_{2}\right), 61.0\left(\mathrm{Py}-\mathrm{CH}_{2}-\mathrm{N}\right), 123.0\left(\mathrm{Py}-C_{3} / \mathrm{Py}-C_{5}\right), 123.9$ $\left(\mathrm{Py}-C_{3} / \mathrm{Py}-C_{5}\right), 137.4\left(\mathrm{Py}-C_{4}\right), 149.8\left(\mathrm{Py}-C_{6}\right), 160.8\left(\mathrm{Py}-C_{2}\right)$. ESI-MS found (calculated) for $[\mathrm{M}+\mathrm{H}]^{+} \mathrm{m} / \mathrm{z} 244.2$ (244.1). IR (neat, $\mathrm{cm}^{-1}$ ): 3270br, 2939w, 2826m, 1592s, 1570m, 1475m, $1433 \mathrm{~s}, 1363 \mathrm{~m}, 1309 \mathrm{w}, 1249 \mathrm{w}, 1149 \mathrm{~m}, 1047 \mathrm{~s}, 1002 \mathrm{~m}, 758 \mathrm{vs}$, 616s, 502m, 469m. 
$\mathbf{P y}_{2} \mathbf{S}$. This ligand was synthesized using a modified literature procedure. ${ }^{27} \mathrm{NaOH}(0.30 \mathrm{~g}, 7.5 \mathrm{mmol})$ was dissolved in a mixture of $10 \mathrm{~mL} \mathrm{H} \mathrm{H}_{2} \mathrm{O}$ and $10 \mathrm{~mL}$ ethanol. $\mathrm{Na}_{2} \mathrm{~S} \cdot 9 \mathrm{H}_{2} \mathrm{O}(0.60 \mathrm{~g}$, $2.5 \mathrm{mmol}$ ) and 2-(chloromethyl)pyridine hydrochloride $(0.82 \mathrm{~g}$, $5.0 \mathrm{mmol}$ ) were added. The mixture was refluxed at $95{ }^{\circ} \mathrm{C}$ for 20 hours and left to cool to RT. The resulting bright orange solution was extracted twice with $20 \mathrm{~mL} \mathrm{CH}_{2} \mathrm{Cl}_{2}$. The organic fractions were combined and dried over $\mathrm{Na}_{2} \mathrm{SO}_{4}$ to yield $\mathbf{P y}_{2} \mathbf{S}$ as a yellow oil $(0.48 \mathrm{~g}, 2.2 \mathrm{mmol}, 88 \%) .{ }^{1} \mathrm{H}$ NMR $(300 \mathrm{MHz}$, $\left.\mathrm{CD}_{3} \mathrm{OD}, \mathrm{RT}\right): \delta 3.82\left(\mathrm{~s}, 4 \mathrm{H}, \mathrm{S}-\mathrm{CH}_{2}-\mathrm{N}\right), 7.25(\mathrm{dd}, J=7 \mathrm{~Hz}, 5 \mathrm{~Hz}$, $\left.2 \mathrm{H}, \mathrm{Py}-H_{5}\right), 7.42\left(\mathrm{~d}, J=8 \mathrm{~Hz}, 2 \mathrm{H}, \mathrm{Py}-H_{3}\right), 7.73(\mathrm{td}, J=8 \mathrm{~Hz}$, $\left.2 \mathrm{~Hz}, 2 \mathrm{H}, \mathrm{Py}-H_{4}\right), 8.42\left(\mathrm{~d}, J=5 \mathrm{~Hz}, 2 \mathrm{H}, \mathrm{Py}-H_{6}\right) .{ }^{13} \mathrm{C} \mathrm{NMR}$ (75 MHz, $\left.\mathrm{CD}_{3} \mathrm{OD}, \mathrm{RT}\right): \delta 38.2\left(\mathrm{~S}-\mathrm{CH}_{2}-\mathrm{N}\right), 123.5\left(\mathrm{Py}-C_{5}\right), 124.9$ $\left(\mathrm{Py}-C_{3}\right), 138.7\left(\mathrm{Py}-C_{4}\right), 149.7\left(\mathrm{Py}-C_{6}\right), 159.4\left(\mathrm{Py}-C_{2}\right)$. ESI-MS found (calculated) for $[\mathrm{M}+\mathrm{H}]^{+} \mathrm{m} / z 217.1$ (217.1). IR (neat, $\mathrm{cm}^{-1}$ ): 3369br, 3050w, 3008w, 2925w, 1590s, 1568m, 1471m, $1434 \mathrm{vs}, 1307 \mathrm{w}, 1208 \mathrm{w}, 1151 \mathrm{w}, 1088 \mathrm{w}, 1048 \mathrm{w}, 994 \mathrm{~m}, 790 \mathrm{~m}$, $747 \mathrm{vs}, 711 \mathrm{~m}, 627 \mathrm{w}, 579 \mathrm{~m}, 484 \mathrm{~m}$.

\subsection{Complex synthesis}

General synthesis procedure. All complexes were synthesized in the same manner unless mentioned otherwise. The ligand was dissolved in methanol, after which $\left[\mathrm{Cu}^{\mathrm{II}}\left(\mathrm{H}_{2} \mathrm{O}\right)_{6}\right]$ $\left(\mathrm{BF}_{4}\right)_{2}$ and $\mathrm{Cu}^{\mathrm{II}} \mathrm{Cl}_{2} \cdot 2 \mathrm{H}_{2} \mathrm{O}$ were added. If there was no formation of powder, diethyl ether was added until precipitation occurred. The powder was filtered and washed with diethyl ether to yield the target complex.

$\left[\mathbf{C u}_{2}^{\mathrm{II}}\left(\mathbf{L}^{1} \mathbf{S S L}^{1}\right)(\mathbf{C l})_{2}\right]_{n}\left(\mathbf{B F}_{4}\right)_{2 n}$. From $\mathbf{L}^{\mathbf{1}} \mathbf{S S L}^{1}$ (67 mg; $\left.0.13 \mathrm{mmol}\right)$, $\left[\mathrm{Cu}^{\mathrm{II}}\left(\mathrm{H}_{2} \mathrm{O}\right)_{6}\right]\left(\mathrm{BF}_{4}\right)_{2} \quad(46 \mathrm{mg} ; 0.13 \mathrm{mmol})$ and $\mathrm{Cu}^{\mathrm{II}} \mathrm{Cl}_{2} \cdot 2 \mathrm{H}_{2} \mathrm{O}$ (22 $\mathrm{mg} ; 0.13 \mathrm{mmol}$ ), the product $\left[\mathrm{Cu}_{2}^{\mathrm{II}}\left(\mathbf{L}^{\mathbf{1}} \mathbf{S S L}^{\mathbf{1}}\right)(\mathrm{Cl})_{2}\right]_{n}\left(\mathrm{BF}_{4}\right)_{2 n}$ (104 mg; $0.12 \mathrm{mmol}$; 90\%) was obtained as a blue powder. Crystals suitable for X-ray structure determination were obtained by slow vapor diffusion of diethyl ether into a $\mathrm{CH}_{3} \mathrm{CN}$ solution containing the complex. ESI-MS found (calculated) for $\left[\mathrm{M}-2 \mathrm{BF}_{4}\right]^{+} \mathrm{m} / z 357.0$ (357.0); $\left[1 / 2 \mathrm{M}-\mathrm{Cl}-\mathrm{BF}_{4}\right]^{+} \mathrm{m} / \mathrm{z}$ 320.9 (321.0); [1/2 M + Cl - $\left.\mathrm{BF}_{4}\right]^{+} \mathrm{m} / z 392.9$ (393.0). IR (neat, $\mathrm{cm}^{-1}$ ): $1610 \mathrm{~m}, 1575 \mathrm{w}, 1486 \mathrm{w}, 1447 \mathrm{~m}, 1303 \mathrm{w}, 1286 \mathrm{w}, 1026 \mathrm{vs}$, 990s, 921m, 820w, 777m, 762s, 719m, 656w, 518m, 476w, 424s. Elemental analysis calcd for $\left[\mathrm{Cu}_{2}^{\mathrm{II}}\left(\mathbf{L}^{\mathbf{1}} \mathbf{S S L}^{\mathbf{1}}\right)(\mathrm{Cl})_{2}\right]\left(\mathrm{BF}_{4}\right)_{2} \cdot \mathrm{H}_{2} \mathrm{O}$ : C 37.11, H 3.78, N 9.27, S 7.07; found: C 37.40, H 3.96, N 9.25, $\mathrm{S}$ 7.23. UV-vis in $\mathrm{CH}_{3} \mathrm{CN}$ at $0.1 \mathrm{mM}$ [Cu] concentration: $258 \mathrm{~nm}$ $\left(\varepsilon=10300 \mathrm{M}^{-1} \mathrm{~cm}^{-1}\right), 289 \mathrm{~nm}\left(\varepsilon=2700 \mathrm{M}^{-1} \mathrm{~cm}^{-1}\right), 680 \mathrm{~nm}$ $\left(\varepsilon=190 \mathrm{M}^{-1} \mathrm{~cm}^{-1}\right)$.

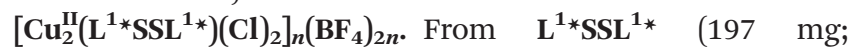
$0.36 \mathrm{mmol}),\left[\mathrm{Cu}^{\mathrm{II}}\left(\mathrm{H}_{2} \mathrm{O}\right)_{6}\right]\left(\mathrm{BF}_{4}\right)_{2}(128 \mathrm{mg} ; 0.36 \mathrm{mmol})$ and $\mathrm{Cu}^{\mathrm{II}} \mathrm{Cl}_{2} \cdot 2 \mathrm{H}_{2} \mathrm{O}(62 \mathrm{mg} ; 0.36 \mathrm{mmol})$, the product $\left[\mathrm{Cu}_{2}^{\mathrm{II}}\left(\mathbf{L}^{\mathbf{1}} \mathbf{S S L}^{\mathbf{1}}\right)\right.$ $\left.(\mathrm{Cl})_{2}\right]_{n}\left(\mathrm{BF}_{4}\right)_{2 n}(245 \mathrm{mg} ; 0.27 \mathrm{mmol} ; 74 \%)$ was obtained as a blue powder. ESI-MS found (calculated) for $\left[\mathrm{M}-2 \mathrm{BF}_{4}\right]^{2+} \mathrm{m} / z$ 371.0 (371.0); $\left[\mathrm{M}+2 \mathrm{Cl}-2 \mathrm{BF}_{4}\right]^{2+} \mathrm{m} / z$ 407.0 (406.0); $[1 / 2$ $\left.\mathrm{M}-\mathrm{Cl}-\mathrm{BF}_{4}\right]^{+} m / z 335.0$ (335.1); $\left[\mathrm{M}-\mathrm{Cu}-\mathrm{Cl}-2 \mathrm{BF}_{4}\right]^{+} m / z$ 642.3 (642.1). IR (neat, $\mathrm{cm}^{-1}$ ): 1611w, 1574w, 1484w, 1446m, $1284 \mathrm{w}, 1162 \mathrm{w}, 1048 \mathrm{vs}, 1030 \mathrm{vs}, 935 \mathrm{~m}, 866 \mathrm{~m}, 819 \mathrm{w}, 765 \mathrm{~s}$, $726 \mathrm{w}, 658 \mathrm{w}, 521 \mathrm{~m}, 420 \mathrm{~m}$. Elemental analysis calcd for $\left[\mathrm{Cu}_{2}^{\mathrm{II}}\left(\mathbf{L}^{\mathbf{1}^{*}} \mathbf{S S L}^{\mathbf{1}^{*}}\right)(\mathrm{Cl})_{2}\right]\left(\mathrm{BF}_{4}\right)_{2}: \mathrm{C}$ 39.32, H 3.96, N 9.17, S 7.00; found: $\mathrm{C} 38.69, \mathrm{H} 3.99, \mathrm{~N}$ 9.19, $\mathrm{S}$ 6.88. UV-vis in $\mathrm{CH}_{3} \mathrm{CN}$ at
$0.1 \mathrm{mM}[\mathrm{Cu}]$ concentration: $258 \mathrm{~nm}\left(\varepsilon=10900 \mathrm{M}^{-1} \mathrm{~cm}^{-1}\right)$, $294 \mathrm{~nm}\left(\varepsilon=2900 \mathrm{M}^{-1} \mathrm{~cm}^{-1}\right), 690 \mathrm{~nm}\left(\varepsilon=210 \mathrm{M}^{-1} \mathrm{~cm}^{-1}\right)$.

$\left[\mathrm{Cu}_{2}^{\text {II }}\left(\mathbf{L}^{2} \mathbf{S S L}^{2}\right)(\mathbf{C l})_{2}\right]_{n}\left(\mathbf{B F}_{4}\right)_{2 n} \cdot \mathbf{L}^{2} \mathbf{S S L}^{2} \quad(72 \mathrm{mg} ; 0.13 \mathrm{mmol})$, $\left[\mathrm{Cu}^{\mathrm{II}}\left(\mathrm{H}_{2} \mathrm{O}\right)_{6}\right]\left(\mathrm{BF}_{4}\right)_{2} \quad(46 \mathrm{mg} ; 0.13 \mathrm{mmol})$ and $\mathrm{Cu}^{\mathrm{II}} \mathrm{Cl}_{2} \cdot 2 \mathrm{H}_{2} \mathrm{O}$ (23 mg; $0.13 \mathrm{mmol}$ ) were dissolved in $5 \mathrm{~mL} \mathrm{CH}_{3} \mathrm{CN}$. Diethyl ether $(13 \mathrm{~mL})$ was added to the bright blue solution. After 15 minutes, the suspension was decanted and filtered. This yielded a bright blue powder that was washed with diethyl ether giving $\left[\mathrm{Cu}_{2}^{\mathrm{II}}\left(\mathbf{L}^{2} \mathbf{S S L}^{2}\right)(\mathrm{Cl})_{2}\right]_{n}\left(\mathrm{BF}_{4}\right)_{2 n}(48 \mathrm{mg} ; 0.05 \mathrm{mmol}$; $40 \%$ ). Single crystals suitable for $\mathrm{X}$-ray structure determination were synthesized from $\left[\mathrm{Cu}^{\mathrm{II}}\left(\mathrm{H}_{2} \mathrm{O}\right)_{6}\right]\left(\mathrm{ClO}_{4}\right)_{2}$ instead of $\left[\mathrm{Cu}^{\mathrm{II}}\left(\mathrm{H}_{2} \mathrm{O}\right)_{6}\right]\left(\mathrm{BF}_{4}\right)_{2}$. Slow vapor diffusion of diethyl ether into a $\mathrm{CH}_{3} \mathrm{CN}$ solution containing the complex, yielded crystals of $\left[\mathrm{Cu}_{2}^{\mathrm{II}}\left(\mathbf{L}^{2} \mathbf{S S L}^{2}\right)(\mathrm{Cl})_{2}\right]_{n}\left(\mathrm{ClO}_{4}\right)_{2 n}$. ESI-MS found (calculated) for $\left[\mathrm{M}-2 \mathrm{BF}_{4}\right]^{2+} \mathrm{m} / \mathrm{z} 371.0(371.0) ;\left[\mathrm{M}+2 \mathrm{Cl}-2 \mathrm{BF}_{4}\right]^{2+} \mathrm{m} / z 406.9$ (406.0); $\left[1 / 2 \mathrm{M}-\mathrm{Cl}-\mathrm{BF}_{4}\right]^{+} \mathrm{m} / z 335.0$ (335.1). IR (neat, $\mathrm{cm}^{-1}$ ): $3554 \mathrm{w}, 1610 \mathrm{~m}, 1577 \mathrm{w}, 1447 \mathrm{~m}, 1287 \mathrm{w}, 1052 \mathrm{vs}, 1028 \mathrm{vs}, 921 \mathrm{~m}$, $790 \mathrm{~m}, 764 \mathrm{~m}, 724 \mathrm{w}, 654 \mathrm{w}, 520 \mathrm{~m}, 474 \mathrm{~m}$. Elemental analysis calcd for $\left[\mathrm{Cu}_{2}^{\mathrm{II}}\left(\mathbf{L}^{2} \mathbf{S S L}^{2}\right)(\mathrm{Cl})_{2}\right]\left(\mathrm{BF}_{4}\right)_{2}$ : C 39.32, H 3.96, N 9.17, S 7.00; found: $\mathrm{C} 39.23, \mathrm{H} 4.01, \mathrm{~N} 9.12, \mathrm{~S}$ 6.96. UV-vis in $\mathrm{CH}_{3} \mathrm{CN}$ at $0.1 \mathrm{mM}[\mathrm{Cu}]$ concentration: $263 \mathrm{~nm}\left(\varepsilon=11600 \mathrm{M}^{-1} \mathrm{~cm}^{-1}\right)$, $303 \mathrm{~nm}\left(\varepsilon=2800 \mathrm{M}^{-1} \mathrm{~cm}^{-1}\right), 720 \mathrm{~nm}\left(\varepsilon=270 \mathrm{M}^{-1} \mathrm{~cm}^{-1}\right)$.

$\left[\mathrm{Cu}_{2}^{\mathrm{II}}\left(\mathbf{L}^{2 *} \mathbf{S S L}^{2 *}\right)(\mathbf{C l})_{2}\right]_{n}\left(\mathbf{B F}_{4}\right)_{2 n}$. From $\mathbf{L}^{{ }^{*} \mathbf{S S L}^{2}} \quad(84 \mathrm{mg}$; $0.15 \mathrm{mmol}),\left[\mathrm{Cu}^{\mathrm{II}}\left(\mathrm{H}_{2} \mathrm{O}\right)_{6}\right]\left(\mathrm{BF}_{4}\right)_{2}(51 \mathrm{mg} ; 0.15 \mathrm{mmol})$ and $\mathrm{Cu}^{\mathrm{II}} \mathrm{Cl}_{2} \cdot 2 \mathrm{H}_{2} \mathrm{O}(25 \mathrm{mg} ; 0.15 \mathrm{mmol})$, the product $\left[\mathrm{Cu}_{2}^{\mathrm{II}}\left(\mathbf{L}^{2 *} \mathbf{S S L}^{2 *}\right)-\right.$ $\left.(\mathrm{Cl})_{2}\right]_{n}\left(\mathrm{BF}_{4}\right)_{2 n}(97 \mathrm{mg} ; 0.10 \mathrm{mmol} ; 70 \%)$ was obtained as a blue powder. ESI-MS found (calculated) for $\left[\mathrm{M}-2 \mathrm{BF}_{4}\right]^{2+} \mathrm{m} / z 386.0$ (385.0); $\left[1 / 2 \mathrm{M}-\mathrm{Cl}-\mathrm{BF}_{4}\right]^{+} m / z 349.1$ (349.1); $[1 / 2 \mathrm{M}+\mathrm{Cl}-$ $\left.\mathrm{BF}_{4}\right]^{+} \mathrm{m} / z 421.0$ (421.0); $\left[\mathrm{M}-\mathrm{Cu}-\mathrm{Cl}-2 \mathrm{BF}_{4}\right]^{+} m / z 670.3$ (670.2). IR (neat, $\mathrm{cm}^{-1}$ ): 3565w, 2934w, 1611m, 1576w, 1447m, 1287w, 1052vs, 1027vs, 867w, 771m, 729w, 654w, 521m. Elemental analysis calcd for $\left[\mathrm{Cu}_{2}^{\mathrm{II}}\left(\mathbf{L}^{2 *} \mathrm{SSL}^{2 *}\right)(\mathrm{Cl})_{2}\right]\left(\mathrm{BF}_{4}\right)_{2}$ : C 40.70, H 4.27, $\mathrm{N}$ 8.90, S 6.79; found: C 39.35, H 4.13, N 8.52, S 6.85. UV-vis in $\mathrm{CH}_{3} \mathrm{CN}$ at $0.1 \mathrm{mM}[\mathrm{Cu}]$ concentration: $264 \mathrm{~nm}\left(\varepsilon=11400 \mathrm{M}^{-1}\right.$ $\left.\mathrm{cm}^{-1}\right), 303 \mathrm{~nm}\left(\varepsilon=3000 \mathrm{M}^{-1} \mathrm{~cm}^{-1}\right), 730 \mathrm{~nm}\left(\varepsilon=270 \mathrm{M}^{-1} \mathrm{~cm}^{-1}\right)$.

$\left[\mathrm{Cu}_{2}{ }^{\text {II }}\left(\mathbf{L}^{3} \mathbf{S S L}^{3}\right)(\mathbf{C l})_{2}\right]_{n}\left(\mathbf{B F}_{4}\right)_{2 n}$. From $\quad \mathbf{L}^{3} \mathbf{S S L}^{3} \quad(153 \quad \mathrm{mg} ;$ $0.27 \mathrm{mmol}),\left[\mathrm{Cu}^{\mathrm{II}}\left(\mathrm{H}_{2} \mathrm{O}\right)_{6}\right]\left(\mathrm{BF}_{4}\right)_{2}(93 \mathrm{mg} ; 0.27 \mathrm{mmol})$ and $\mathrm{Cu}^{\mathrm{II}} \mathrm{Cl}_{2} \cdot 2 \mathrm{H}_{2} \mathrm{O}(46 \mathrm{mg} ; 0.27 \mathrm{mmol})$, the product $\left[\mathrm{Cu}_{2}^{\mathrm{II}}\left(\mathbf{L}^{3} \mathbf{S S L}^{3}\right)\right.$ $\left.(\mathrm{Cl})_{2}\right]_{n}\left(\mathrm{BF}_{4}\right)_{2 n}(207 \mathrm{mg} ; 0.22 \mathrm{mmol} ; 82 \%)$ was obtained as a blue powder. ESI-MS found (calculated) for $\left[1 / 2 \mathrm{M}-\mathrm{Cl}-\mathrm{BF}_{4}\right]^{+}$ $m / z 349.0$ (349.1); [M - Cu - $\left.2 \mathrm{Cl}-2 \mathrm{BF}_{4}\right]^{2+} m / z 318.1$ (317.6); $\left[\mathrm{M}-\mathrm{Cu}-2 \mathrm{Cl}-2 \mathrm{BF}_{4}\right]^{+} \mathrm{m} / z 635.3$ (635.2). IR (neat, $\mathrm{cm}^{-1}$ ): $2938 \mathrm{w}, 1612 \mathrm{~m}, 1577 \mathrm{w}, 1474 \mathrm{~m}, 1459 \mathrm{~m}, 1417 \mathrm{w}, 1386 \mathrm{w}, 1349 \mathrm{w}$, $1274 \mathrm{w}, 1243 \mathrm{w}, 1172 \mathrm{w}, 1049 \mathrm{vs}, 986 \mathrm{vs}, 923 \mathrm{~m}, 852 \mathrm{~m}, 805 \mathrm{~m}$, $722 \mathrm{~m}, 519 \mathrm{~m}$. Elemental analysis calcd for $\left[\mathrm{Cu}_{2}^{\mathrm{II}}\left(\mathbf{L}^{3} \mathbf{S S L}^{3}\right)(\mathrm{Cl})_{2}\right]$ $\left(\mathrm{BF}_{4}\right)_{2}$ : C 40.70, H 4.27, N 8.90, S 6.79; found: C 39.90, H 4.21, $\mathrm{N}$ 8.86, S 6.81. UV-vis in $\mathrm{CH}_{3} \mathrm{CN}$ at $0.1 \mathrm{mM}$ [Cu] concentration: $265 \mathrm{~nm}\left(\varepsilon=13000 \mathrm{M}^{-1} \mathrm{~cm}^{-1}\right), 343 \mathrm{~nm}\left(\varepsilon=1600 \mathrm{M}^{-1} \mathrm{~cm}^{-1}\right)$, $640 \mathrm{~nm}\left(\varepsilon=180 \mathrm{M}^{-1} \mathrm{~cm}^{-1}\right), 750 \mathrm{~nm}\left(\varepsilon=200 \mathrm{M}^{-1} \mathrm{~cm}^{-1}\right)$.

$\left[\mathbf{C u}_{2}^{\text {II }}\left(\mathbf{L}^{\mathbf{4}} \mathbf{S S L}^{\mathbf{4}}\right)(\mathbf{C l})_{2}\right]_{n}\left(\mathbf{B F}_{4}\right)_{2 n}$. From $\quad \mathbf{L}^{\mathbf{4}} \mathbf{S S L}^{\mathbf{4}} \quad(96 \quad \mathrm{mg} ;$ $0.18 \mathrm{mmol}),\left[\mathrm{Cu}^{\mathrm{II}}\left(\mathrm{H}_{2} \mathrm{O}\right)_{6}\right]\left(\mathrm{BF}_{4}\right)_{2}(61 \mathrm{mg} ; 0.18 \mathrm{mmol})$ and $\mathrm{Cu}^{\mathrm{II}} \mathrm{Cl}_{2} \cdot 2 \mathrm{H}_{2} \mathrm{O}(30 \mathrm{mg} ; 0.18 \mathrm{mmol})$, the product $\left[\mathrm{Cu}_{2}^{\mathrm{II}}\left(\mathbf{L}^{\mathbf{4}} \mathbf{S S L}^{4}\right)\right.$ $\left.(\mathrm{Cl})_{2}\right]_{n}\left(\mathrm{BF}_{4}\right)_{2 n}(110 \mathrm{mg} ; 0.12 \mathrm{mmol} ; 68 \%)$ was obtained as a greyish blue powder. ESI-MS found (calculated) for $\left[\mathrm{M}-2 \mathrm{BF}_{4}\right]^{2+}$ $\mathrm{m} / \mathrm{z} 371.0$ (371.0); $\left[\mathrm{M}+2 \mathrm{Cl}-2 \mathrm{BF}_{4}\right]^{2+} \mathrm{m} / \mathrm{z} 406.9$ (406.0); [1/2 $\mathrm{M}-$ $\left.\mathrm{Cl}-\mathrm{BF}_{4}\right]^{+} m / z 335.0$ (335.1); $\left[\mathrm{M}-\mathrm{Cu}-\mathrm{Cl}-2 \mathrm{BF}_{4}\right]^{+} m / z 642.3$ 
(642.1). IR (neat, $\mathrm{cm}^{-1}$ ): 3628w, 1612m, 1574w, 1487w, 1448m, $1319 \mathrm{w}, 1300 \mathrm{w}, 1165 \mathrm{w}, 1054 \mathrm{vs}, 1029 \mathrm{vs}, 946 \mathrm{~m}, 769 \mathrm{~s}, 724 \mathrm{w}$, 655w, 588w, 520m, 479m. Elemental analysis calcd for $\left[\mathrm{Cu}_{2}^{\mathrm{II}}\left(\mathrm{L}^{4} \mathrm{SSL}^{4}\right)(\mathrm{Cl})_{2}\right]\left(\mathrm{BF}_{4}\right)_{2} \cdot \mathrm{H}_{2} \mathrm{O}: \mathrm{C}$ 38.56, H 4.10, N 8.99, S 6.86; found: $\mathrm{C}$ 38.45, $\mathrm{H}$ 4.36, $\mathrm{N}$ 9.12, $\mathrm{S}$ 7.03. UV-vis in $\mathrm{CH}_{3} \mathrm{CN}$ at $0.1 \mathrm{mM}[\mathrm{Cu}]$ concentration: $261 \mathrm{~nm}\left(\varepsilon=11500 \mathrm{M}^{-1} \mathrm{~cm}^{-1}\right)$, $293 \mathrm{~nm}\left(\varepsilon=3600 \mathrm{M}^{-1} \mathrm{~cm}^{-1}\right), 580 \mathrm{~nm}\left(\varepsilon=200 \mathrm{M}^{-1} \mathrm{~cm}^{-1}\right)$, $670 \mathrm{~nm}\left(\varepsilon=180 \mathrm{M}^{-1} \mathrm{~cm}^{-1}\right)$.

$\left[\mathbf{C u}_{2}^{\text {II }}\left(\mathbf{L}^{5} \mathbf{S S L}^{5}\right)(\mathbf{C l})_{2}\right]_{n}\left(\mathbf{B F}_{4}\right)_{2 n}$. This complex was formed in situ. $\mathrm{CH}_{3} \mathrm{CN}$ at $0.1 \mathrm{mM}[\mathrm{Cu}]$ concentration: $263 \mathrm{~nm}\left(\varepsilon=10800 \mathrm{M}^{-1}\right.$ $\left.\mathrm{cm}^{-1}\right), 292 \mathrm{~nm}\left(\varepsilon=3600 \mathrm{M}^{-1} \mathrm{~cm}^{-1}\right), 342 \mathrm{~nm}\left(\varepsilon=1900 \mathrm{M}^{-1}\right.$ $\left.\mathrm{cm}^{-1}\right), 710 \mathrm{~nm}\left(\varepsilon=170 \mathrm{M}^{-1} \mathrm{~cm}^{-1}\right)$.

$\left[\mathbf{C u}_{2}^{\mathbf{I I}}\left(\mathbf{L}^{\mathbf{1}} \mathbf{S X S L}^{\mathbf{1}}\right)(\mathbf{C l})_{2}\right]_{n}\left(\mathbf{B F}_{4}\right)_{2 n}$. From $\quad \mathbf{L}^{\mathbf{1}} \mathbf{S X S L}^{\mathbf{1}} \quad(23 \quad \mathrm{mg} ;$ $0.04 \mathrm{mmol}),\left[\mathrm{Cu}^{\mathrm{II}}\left(\mathrm{H}_{2} \mathrm{O}\right)_{6}\right]\left(\mathrm{BF}_{4}\right)_{2}(15 \mathrm{mg} ; 0.04 \mathrm{mmol})$ and $\mathrm{Cu}^{\mathrm{II}} \mathrm{Cl}_{2} \cdot 2 \mathrm{H}_{2} \mathrm{O}(7.4 \mathrm{mg} ; 0.04 \mathrm{mmol})$ in $\mathrm{CH}_{3} \mathrm{CN}$, the product $\left[\mathrm{Cu}_{2}^{\mathrm{II}}\left(\mathbf{L}^{\mathbf{1}} \mathbf{S X S L}{ }^{\mathbf{1}}\right)(\mathrm{Cl})_{2}\right]_{n}\left(\mathrm{BF}_{4}\right)_{2 n}(34 \mathrm{mg} ; 0.04 \mathrm{mmol} ; 86 \%)$ was obtained as a light blue powder. ESI-MS found (calculated) for $\left[\mathrm{M}-2 \mathrm{BF}_{4}\right]^{2+} \mathrm{m} / z 370.0$ (370.0). IR (neat, $\mathrm{cm}^{-1}$ ): 3612w, 1611m, $1574 \mathrm{w}, 1484 \mathrm{w}, 1447 \mathrm{~m}, 1287 \mathrm{w}, 1162 \mathrm{w}, 1054 \mathrm{vs}, 1030 \mathrm{vs}, 901 \mathrm{w}$, $852 \mathrm{w}, 819 \mathrm{w}, 765 \mathrm{~s}, 728 \mathrm{w}, 656 \mathrm{w}, 521 \mathrm{~m}$. Elemental analysis calcd for $\left[\mathrm{Cu}_{2}^{\mathrm{II}}\left(\mathbf{L}^{\mathbf{1}} \mathbf{S X S L}^{\mathbf{1}}\right)(\mathrm{Cl})_{2}\right]\left(\mathrm{BF}_{4}\right)_{2}$ : C 39.41, H 3.75, N 9.19, S 7.01; found: $\mathrm{C}$ 38.56, $\mathrm{H}$ 3.73, N 9.04, $\mathrm{S}$ 6.85. UV-vis in $\mathrm{CH}_{3} \mathrm{CN}$ at $0.1 \mathrm{mM}[\mathrm{Cu}]$ concentration: $257 \mathrm{~nm}\left(\varepsilon=10800 \mathrm{M}^{-1} \mathrm{~cm}^{-1}\right)$, $290 \mathrm{~nm}\left(\varepsilon=3000 \mathrm{M}^{-1} \mathrm{~cm}^{-1}\right), 700 \mathrm{~nm}\left(\varepsilon=190 \mathrm{M}^{-1} \mathrm{~cm}^{-1}\right)$.

$\left[\mathbf{C u}_{2}^{\text {II }}\left(\mathbf{L}^{1} \mathbf{S L}^{1}\right)(\mathbf{C l})_{2}\right]_{n}\left(\mathbf{B F}_{4}\right)_{2 n}$. From $\mathbf{L}^{1} \mathbf{S L}^{1}(275 \mathrm{mg} ; 0.57 \mathrm{mmol})$, $\left[\mathrm{Cu}^{\mathrm{II}}\left(\mathrm{H}_{2} \mathrm{O}\right)_{6}\right]\left(\mathrm{BF}_{4}\right)_{2}(196 \mathrm{mg} ; 0.57 \mathrm{mmol})$ and $\mathrm{Cu}^{\mathrm{II}} \mathrm{Cl}_{2} \cdot 2 \mathrm{H}_{2} \mathrm{O}$ (97 $\mathrm{mg} ; 0.57 \mathrm{mmol}$ ), the product $\left[\mathrm{Cu}_{2}^{\mathrm{II}}\left(\mathbf{L}^{\mathbf{1}} \mathbf{S L}^{\mathbf{1}}\right)(\mathrm{Cl})_{2}\right]_{n}\left(\mathrm{BF}_{4}\right)_{2 n}$ (370 mg; $0.43 \mathrm{mmol}$; 76\%) was obtained as a light blue powder. Crystals suitable for X-ray structure determination were obtained by slow vapor diffusion of diethyl ether into a $\mathrm{CH}_{3} \mathrm{CN}$ solution containing the complex. ESI-MS found (calculated) for $\left[\mathrm{M}-2 \mathrm{BF}_{4}\right]^{2+} \mathrm{m} / z 341.0$ (341.0). IR (neat, $\mathrm{cm}^{-1}$ ): $3612 \mathrm{w}, 1611 \mathrm{~m}, 1574 \mathrm{w}, 1481 \mathrm{w}, 1444 \mathrm{~m}, 1290 \mathrm{w}, 1088 \mathrm{~m}, 1049 \mathrm{vs}$, 1030vs, 995m, 973w, 946w, 906w, 819w, 777m, 761m, 717m, 654w, 521w. Elemental analysis calcd for $\left[\mathrm{Cu}_{2}^{\mathrm{II}}\left(\mathbf{L}^{1} \mathbf{S L}^{\mathbf{1}}\right)(\mathrm{Cl})_{2}\right]$ $\left(\mathrm{BF}_{4}\right)_{2}$ : C 39.28, H 3.77, N 9.81, S 3.74; found: C 40.13, H 3.85, $\mathrm{N}$ 10.15, S 3.67. UV-vis in $\mathrm{CH}_{3} \mathrm{CN}$ at $0.1 \mathrm{mM}[\mathrm{Cu}]$ concentration: $256 \mathrm{~nm}\left(\varepsilon=10600 \mathrm{M}^{-1} \mathrm{~cm}^{-1}\right), 290 \mathrm{~nm}\left(\varepsilon=2900 \mathrm{M}^{-1}\right.$ $\left.\mathrm{cm}^{-1}\right), 690 \mathrm{~nm}\left(\varepsilon=110 \mathrm{M}^{-1} \mathrm{~cm}^{-1}\right)$.

$\left[\mathbf{C u}_{2}^{\text {II }}\left(\mathbf{L}^{1} \mathbf{C}_{6} \mathbf{L}^{1}\right)(\mathbf{C l})_{2}\right]_{n}\left(\mathbf{B F}_{4}\right)_{2 n}$. From $\mathbf{L}^{1} \mathbf{C}_{6} \mathbf{L}^{\mathbf{1}}$ (102 mg; $\left.0.21 \mathrm{mmol}\right)$, $\left[\mathrm{Cu}^{\mathrm{II}}\left(\mathrm{H}_{2} \mathrm{O}\right)_{6}\right]\left(\mathrm{BF}_{4}\right)_{2}(74 \mathrm{mg} ; 0.21 \mathrm{mmol})$ and $\mathrm{Cu}^{\mathrm{II}} \mathrm{Cl}_{2} \cdot 2 \mathrm{H}_{2} \mathrm{O}$ (36 $\mathrm{mg} ; 0.21 \mathrm{mmol}$ ), the product $\left[\mathrm{Cu}_{2}^{\mathrm{II}}\left(\mathbf{L}^{\mathbf{1}} \mathbf{C}_{\mathbf{6}} \mathbf{L}^{\mathbf{1}}\right)(\mathrm{Cl})_{2}\right]_{n}\left(\mathrm{BF}_{4}\right)_{2 n}$ (158 mg; $0.19 \mathrm{mmol}$; 87\%) was obtained as a dark blue powder. Crystals suitable for X-ray structure determination were obtained by slow vapor diffusion of di-isopropyl ether into a $\mathrm{CH}_{3} \mathrm{CN}$ solution containing the complex. ESI-MS found (calculated) for $\left[\mathrm{M}-2 \mathrm{BF}_{4}\right]^{2+} \mathrm{m} / z 339.1$ (339.1). IR (neat, $\mathrm{cm}^{-1}$ ): 3090w, 2933w, 2853w, 1612m, 1574w, 1484w, 1446m, $1283 \mathrm{~m}, 1088 \mathrm{~m}, 1049 \mathrm{vs}, 1031 \mathrm{vs}, 897 \mathrm{~m}, 883 \mathrm{~m}, 817 \mathrm{w}$, 766s, 726w, 660w, 521m, 492w. Elemental analysis calcd for $\left[\mathrm{Cu}_{2}^{\mathrm{II}}\left(\mathbf{L}^{\mathbf{1}} \mathbf{C}_{6} \mathbf{L}^{\mathbf{1}}\right)(\mathrm{Cl})_{2}\right]\left(\mathrm{BF}_{4}\right)_{2}$ : C 42.28, $\mathrm{H}$ 4.26, N 9.86; found: $\mathrm{C} 42.49, \mathrm{H}$ 4.35, $\mathrm{N}$ 9.93. UV-vis in $\mathrm{CH}_{3} \mathrm{CN}$ at $0.1 \mathrm{mM}[\mathrm{Cu}]$ concentration: $256 \mathrm{~nm}\left(\varepsilon=11800 \mathrm{M}^{-1} \mathrm{~cm}^{-1}\right), 291 \mathrm{~nm}$ $\left(\varepsilon=3000 \mathrm{M}^{-1} \mathrm{~cm}^{-1}\right), 660 \mathrm{~nm}\left(\varepsilon=140 \mathrm{M}^{-1} \mathrm{~cm}^{-1}\right)$.

$\left[\mathbf{C u}_{2}{ }^{\text {II }}\left(\mathbf{L}^{1} \mathbf{P h L}^{1}\right)(\mathbf{C l})_{2}\right]_{n}\left(\mathbf{B F}_{4}\right)_{2 n}$. From $\quad \mathbf{L}^{1} \mathbf{P h L}^{\mathbf{1}} \quad(166 \quad \mathrm{mg} ;$ $0.35 \mathrm{mmol}),\left[\mathrm{Cu}^{\mathrm{II}}\left(\mathrm{H}_{2} \mathrm{O}\right)_{6}\right]\left(\mathrm{BF}_{4}\right)_{2}(121 \mathrm{mg} ; 0.35 \mathrm{mmol})$ and

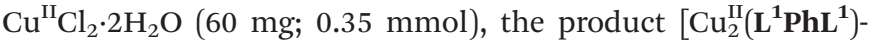
$\left.(\mathrm{Cl})_{2}\right]_{n}\left(\mathrm{BF}_{4}\right)_{2 n}(249 \mathrm{mg} ; 0.30 \mathrm{mmol} ; 84 \%)$ was obtained as a green powder. ESI-MS found (calculated) for $\left[\mathrm{M}-2 \mathrm{BF}_{4}\right]^{2+} \mathrm{m} / \mathrm{z}$ 335.0 (335.0); $\left[\mathrm{M}-\mathrm{Cu}-\mathrm{Cl}-2 \mathrm{BF}_{4}\right]^{+} \mathrm{m} / z 570.2$ (570.1). IR (neat, $\mathrm{cm}^{-1}$ ): $2972 \mathrm{w}, 1611 \mathrm{~m}, 1575 \mathrm{w}, 1486 \mathrm{w}, 1449 \mathrm{~m}, 1288 \mathrm{~m}$, 1052vs, 1031vs, $870 \mathrm{~m}, 769 \mathrm{~s}, 698 \mathrm{~m}, 657 \mathrm{~m}, 538 \mathrm{w}, 521 \mathrm{~m}$. Elemental analysis calcd for $\left[\mathrm{Cu}_{2}^{\mathrm{II}}\left(\mathbf{L}^{\mathbf{1}} \mathbf{P h} \mathbf{L}^{\mathbf{1}}\right)(\mathrm{Cl})_{2}\right]\left(\mathrm{BF}_{4}\right)_{2} \cdot 2 \mathrm{CH}_{3} \mathrm{CN}$ : $\mathrm{C}$ 44.09, $\mathrm{H}$ 3.70, N 12.10; found: C 43.18, H 3.82, N 11.80. UV-vis in $\mathrm{CH}_{3} \mathrm{CN}$ at $0.1 \mathrm{mM}$ [Cu] concentration: $260 \mathrm{~nm}(\varepsilon=$ $\left.11500 \mathrm{M}^{-1} \mathrm{~cm}^{-1}\right), 310 \mathrm{~nm}\left(\varepsilon=2000 \mathrm{M}^{-1} \mathrm{~cm}^{-1}\right), 380 \mathrm{~nm}(\varepsilon=$ $\left.410 \mathrm{M}^{-1} \mathrm{~cm}^{-1}\right), 700 \mathrm{~nm}\left(\varepsilon=150 \mathrm{M}^{-1} \mathrm{~cm}^{-1}\right)$.

$\left[\mathbf{C u}^{\mathrm{II}}\left(\mathbf{P y}_{3} \mathbf{N}\right)(\mathbf{C l})\right]\left(\mathbf{B F}_{4}\right)$. From $\mathbf{P y}_{3} \mathbf{N}(160 \mathrm{mg} ; 0.55 \mathrm{mmol})$, $\left[\mathrm{Cu}^{\mathrm{II}}\left(\mathrm{H}_{2} \mathrm{O}\right)_{6}\right]\left(\mathrm{BF}_{4}\right)_{2}(96 \mathrm{mg} ; 0.28 \mathrm{mmol})$ and $\mathrm{Cu}^{\mathrm{II}} \mathrm{Cl}_{2} \cdot 2 \mathrm{H}_{2} \mathrm{O}$ (47 mg; $0.28 \mathrm{mmol})$, the product $\left[\mathrm{Cu}^{\mathrm{II}}\left(\mathbf{P y}_{3} \mathbf{N}\right)(\mathrm{Cl})\right]\left(\mathrm{BF}_{4}\right)(251 \mathrm{mg}$; $0.53 \mathrm{mmol}$; 96\%) was obtained as a mint green powder. ESI-MS found (calculated) for $\left[\mathrm{M}-\mathrm{BF}_{4}\right]^{+} \mathrm{m} / \mathrm{z} 388.0$ (388.1). IR (neat, $\mathrm{cm}^{-1}$ ): $2974 \mathrm{w}, 1607 \mathrm{~m}, 1575 \mathrm{w}, 1480 \mathrm{w}, 1438 \mathrm{~m}, 1307 \mathrm{w}$, $1263 \mathrm{w}, 1159 \mathrm{w}, 1113 \mathrm{w}, 1090 \mathrm{~m}, 1047 \mathrm{vs}, 1021 \mathrm{~s}, 958 \mathrm{~m}, 841 \mathrm{w}$, $771 \mathrm{~m}, 761 \mathrm{~s}, 643 \mathrm{w}, 506 \mathrm{~m}$. Elemental analysis calcd for $\left[\mathrm{Cu}^{\mathrm{II}}\left(\mathrm{Py}_{3} \mathbf{N}\right)(\mathrm{Cl})\right]\left(\mathrm{BF}_{4}\right): \mathrm{C} 43.75, \mathrm{H} 4.08, \mathrm{~N} 11.34$; found: $\mathrm{C} 44.88$, $\mathrm{H}$ 4.40, $\mathrm{N}$ 11.59. UV-vis in $\mathrm{CH}_{3} \mathrm{CN}$ at $0.1 \mathrm{mM}[\mathrm{Cu}]$ concentration: $230 \mathrm{~nm}\left(\varepsilon=7600 \mathrm{M}^{-1} \mathrm{~cm}^{-1}\right), 261 \mathrm{~nm}\left(\varepsilon=12100 \mathrm{M}^{-1}\right.$ $\left.\mathrm{cm}^{-1}\right), 299 \mathrm{~nm}\left(\varepsilon=3100 \mathrm{M}^{-1} \mathrm{~cm}^{-1}\right), 730 \mathrm{~nm}\left(\varepsilon=90 \mathrm{M}^{-1} \mathrm{~cm}^{-1}\right)$, $940 \mathrm{~nm}\left(\varepsilon=200 \mathrm{M}^{-1} \mathrm{~cm}^{-1}\right)$.

$\left[\mathbf{C u}^{\text {II }}\left(\mathbf{L}^{1} \mathbf{S C H}_{3}\right)(\mathbf{C l})\right]\left(\mathbf{B F}_{4}\right)$. From $\mathbf{L}^{1} \mathbf{S C H}_{3}(94 \mathrm{mg} ; 0.34 \mathrm{mmol})$, $\left[\mathrm{Cu}^{\mathrm{II}}\left(\mathrm{H}_{2} \mathrm{O}\right)_{6}\right]\left(\mathrm{BF}_{4}\right)_{2} \quad(59 \mathrm{mg} ; 0.17 \mathrm{mmol})$ and $\mathrm{Cu}^{\mathrm{II}} \mathrm{Cl}_{2} \cdot 2 \mathrm{H}_{2} \mathrm{O}$ (29 $\mathrm{mg} ; 0.17 \mathrm{mmol})$, the product $\left[\mathrm{Cu}^{\mathrm{II}}\left(\mathbf{L}^{\mathbf{1}} \mathbf{S C H} \mathbf{H}_{3}\right)(\mathrm{Cl})\right]\left(\mathrm{BF}_{4}\right)$ (110 mg; $0.24 \mathrm{mmol}$; 70\%) was obtained as a dark blue crystalline solid. Crystals suitable for X-ray structure determination were obtained by slow vapor diffusion of diethyl ether into a methanol solution containing the complex. ESI-MS found (calculated) for $\left[\mathrm{M}-\mathrm{BF}_{4}\right]^{+} \mathrm{m} / z 370.9$ (371.0). IR (neat, $\mathrm{cm}^{-1}$ ): $1611 \mathrm{~m}, 1441 \mathrm{~m}, 1284 \mathrm{~m}, 1046 \mathrm{vs}, 1029 \mathrm{vs}, 1002 \mathrm{~m}, 907 \mathrm{~m}, 783 \mathrm{~m}$, $759 \mathrm{~m}, 519 \mathrm{~m}$. Elemental analysis calcd for $\left[\mathrm{Cu}^{\mathrm{II}}\left(\mathbf{L}^{\mathbf{1}} \mathbf{S C H}_{3}\right)(\mathrm{Cl})\right]-$ $\left(\mathrm{BF}_{4}\right)$ : C 39.23, H 4.17, N 9.15, S 6.98; found: C 39.73, H 4.44, $\mathrm{N} 9.25, \mathrm{~S} 7.05$. UV-vis in acetonitrile at $0.1 \mathrm{mM}[\mathrm{Cu}]$ concentration: $258 \mathrm{~nm}\left(\varepsilon=10800 \mathrm{M}^{-1} \mathrm{~cm}^{-1}\right), 297 \mathrm{~nm}\left(\varepsilon=3400 \mathrm{M}^{-1}\right.$ $\left.\mathrm{cm}^{-1}\right), 700 \mathrm{~nm}\left(\varepsilon=130 \mathrm{M}^{-1} \mathrm{~cm}^{-1}\right), 890 \mathrm{~nm}\left(\varepsilon=170 \mathrm{M}^{-1} \mathrm{~cm}^{-1}\right)$.

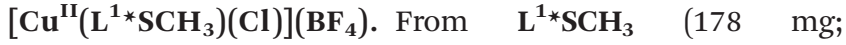
$0.62 \mathrm{mmol}),\left[\mathrm{Cu}^{\mathrm{II}}\left(\mathrm{H}_{2} \mathrm{O}\right)_{6}\right]\left(\mathrm{BF}_{4}\right)_{2}(107 \mathrm{mg} ; 0.31 \mathrm{mmol})$ and $\mathrm{Cu}^{\mathrm{II}} \mathrm{Cl}_{2} \cdot 2 \mathrm{H}_{2} \mathrm{O}$ (53 mg; $\left.0.31 \mathrm{mmol}\right)$, the product $\left[\mathrm{Cu}^{\mathrm{II}}\left(\mathbf{L}^{\mathbf{1}} \mathbf{S C H}_{3}\right)-\right.$ $(\mathrm{Cl})]\left(\mathrm{BF}_{4}\right)(157 \mathrm{mg} ; 0.33 \mathrm{mmol} ; 54 \%)$ was obtained as a blue powder. Crystals suitable for X-ray structure determination were obtained by slow vapor diffusion of diethyl ether into a methanol solution containing the complex. ESI-MS found (calculated) for $\left[\mathrm{M}-\mathrm{BF}_{4}\right]^{+} \mathrm{m} / z 385.0$ (385.0). IR (neat, $\mathrm{cm}^{-1}$ ): $1609 \mathrm{~m}, 1573 \mathrm{w}, 1483 \mathrm{w}, 1444 \mathrm{~m}, 1302 \mathrm{w}, 1285 \mathrm{w}, 1160 \mathrm{w}, 1054 \mathrm{vs}$, 1028vs, 863w, 820w, 766s, 652w, 520m. Elemental analysis calcd for $\left[\mathrm{Cu}^{\mathrm{II}}\left(\mathbf{L}^{\mathbf{1}^{*}} \mathbf{S C H}_{3}\right)(\mathrm{Cl})\right]\left(\mathrm{BF}_{4}\right)$ : C 40.61, H 4.47, N 8.88, $\mathrm{S}$ 6.78; found: $\mathrm{C} 40.17, \mathrm{H} 4.51, \mathrm{~N}$ 8.68, $\mathrm{S}$ 7.03. UV-vis in $\mathrm{CH}_{3} \mathrm{CN}$ at $0.1 \mathrm{mM}[\mathrm{Cu}]$ concentration: $257 \mathrm{~nm}\left(\varepsilon=11000 \mathrm{M}^{-1} \mathrm{~cm}^{-1}\right)$, $299 \mathrm{~nm}\left(\varepsilon=3600 \mathrm{M}^{-1} \mathrm{~cm}^{-1}\right), 690 \mathrm{~nm}\left(\varepsilon=130 \mathrm{M}^{-1} \mathrm{~cm}^{-1}\right)$, $880 \mathrm{~nm}\left(\varepsilon=160 \mathrm{M}^{-1} \mathrm{~cm}^{-1}\right)$.

$\left[\mathbf{C u}^{\mathrm{II}}\left(\mathbf{L}^{2} \mathbf{S C H}_{3}\right)(\mathbf{C l})\right]\left(\mathbf{B F}_{4}\right)$. From $\mathbf{L}^{2} \mathbf{S C H}_{3}(116 \mathrm{mg} ; 0.40 \mathrm{mmol})$, $\left[\mathrm{Cu}^{\mathrm{II}}\left(\mathrm{H}_{2} \mathrm{O}\right)_{6}\right]\left(\mathrm{BF}_{4}\right)_{2}(70 \mathrm{mg} ; 0.20 \mathrm{mmol})$ and $\mathrm{Cu}^{\mathrm{II}} \mathrm{Cl}_{2} \cdot 2 \mathrm{H}_{2} \mathrm{O}$ (35 $\mathrm{mg} ; 0.20 \mathrm{mmol})$, the product $\left[\mathrm{Cu}^{\mathrm{II}}\left(\mathbf{L}^{2} \mathbf{S C H} \mathbf{H}_{3}\right)(\mathrm{Cl})\right]\left(\mathrm{BF}_{4}\right)$ 
(96 mg; $0.20 \mathrm{mmol}$; 50\%) was obtained as a blue powder. Crystals suitable for X-ray structure determination were obtained by slow vapor diffusion of diethyl ether into a methanol solution containing the complex. ESI-MS found (calculated) for $\left[\mathrm{M}-\mathrm{BF}_{4}\right]^{+} \mathrm{m} / z 385.0$ (385.0); $\left[\mathrm{M}-\mathrm{Cl}-\mathrm{BF}_{4}\right]^{+} \mathrm{m} / z 350.0$ (350.1). IR (neat, $\mathrm{cm}^{-1}$ ): 2932w, 1610m, 1578w, 1460w, 1445m, 1287w, $1175 \mathrm{w}, 1050 \mathrm{vs}, 1026 \mathrm{vs}, 961 \mathrm{~m}, 911 \mathrm{~m}, 791 \mathrm{~m}, 764 \mathrm{~m}, 725 \mathrm{w}, 654 \mathrm{w}$, $520 \mathrm{~m}$. Elemental analysis calcd for $\left[\mathrm{Cu}^{\mathrm{II}}\left(\mathbf{L}^{2} \mathbf{S C H}\right)(\mathrm{Cl})\right]\left(\mathrm{BF}_{4}\right)$ : C 40.61, H 4.47, N 8.88, S 6.78; found: C 40.64, H 4.59, N 8.78, $\mathrm{S}$ 6.71. UV-vis in $\mathrm{CH}_{3} \mathrm{CN}$ at $0.1 \mathrm{mM}$ [Cu] concentration: $265 \mathrm{~nm}$ $\left(\varepsilon=10300 \mathrm{M}^{-1} \mathrm{~cm}^{-1}\right), 305 \mathrm{~nm}\left(\varepsilon=3600 \mathrm{M}^{-1} \mathrm{~cm}^{-1}\right), 350 \mathrm{~nm}$ $\left(\varepsilon=2300 \mathrm{M}^{-1} \mathrm{~cm}^{-1}\right), 690 \mathrm{~nm}\left(\varepsilon=320 \mathrm{M}^{-1} \mathrm{~cm}^{-1}\right), 870 \mathrm{~nm}(\varepsilon=$ $\left.310 \mathrm{M}^{-1} \mathrm{~cm}^{-1}\right)$.

$\left[\mathbf{C u}^{\mathrm{II}}\left(\mathbf{L}^{3} \mathbf{S C H}_{3}\right)(\mathbf{C l})\right]\left(\mathrm{BF}_{4}\right)$. From $\mathbf{L}^{3} \mathbf{S C H}_{3}(154 \mathrm{mg} ; 0.51 \mathrm{mmol})$, $\left[\mathrm{Cu}^{\mathrm{II}}\left(\mathrm{H}_{2} \mathrm{O}\right)_{6}\right]\left(\mathrm{BF}_{4}\right)_{2}(88 \mathrm{mg} ; 0.26 \mathrm{mmol})$ and $\mathrm{Cu}^{\mathrm{II}} \mathrm{Cl}_{2} \cdot 2 \mathrm{H}_{2} \mathrm{O}$ (44 mg; $0.26 \mathrm{mmol}$ ), the product $\left[\mathrm{Cu}^{\mathrm{II}}\left(\mathbf{L}^{3} \mathbf{S} \mathbf{C} \mathbf{H}_{3}\right)(\mathrm{Cl})\right]\left(\mathrm{BF}_{4}\right)$ (195 mg; $0.40 \mathrm{mmol}$; 78\%) was obtained as a dark blue powder. Crystals suitable for X-ray structure determination were obtained by slow vapor diffusion of diethyl ether into a methanol solution containing the complex. ESI-MS found (calculated) for $\left[\mathrm{M}-\mathrm{BF}_{4}\right]^{+} \mathrm{m} / \mathrm{z} 399.0$ (399.1); $\left[\mathrm{M}-\mathrm{Cl}-\mathrm{BF}_{4}\right]^{+} \mathrm{m} / \mathrm{z}$ 364.0 (364.1). IR (neat, $\mathrm{cm}^{-1}$ ): 2929w, 1610m, 1576w, 1474m, $1457 \mathrm{~m}, 1432 \mathrm{w}, 1349 \mathrm{w}, 1287 \mathrm{w}, 1241 \mathrm{w}, 1094 \mathrm{~m}, 1049 \mathrm{vs}, 1027 \mathrm{vs}$, 964m, 915w, 803s, 792m, 773m, 648w, 520m. Elemental analysis calcd for $\left[\mathrm{Cu}^{\mathrm{II}}\left(\mathbf{L}^{3} \mathbf{S C H}_{3}\right)(\mathrm{Cl})\right]\left(\mathrm{BF}_{4}\right): \mathrm{C} 41.90, \mathrm{H} 4.76, \mathrm{~N} 8.62$, S 6.58; found: $\mathrm{C} 42.08, \mathrm{H} 4.73, \mathrm{~N}$ 8.69, $\mathrm{S}$ 6.52. UV-vis in $\mathrm{CH}_{3} \mathrm{CN}$ at $0.1 \mathrm{mM}[\mathrm{Cu}]$ concentration: $267 \mathrm{~nm}\left(\varepsilon=11700 \mathrm{M}^{-1} \mathrm{~cm}^{-1}\right)$, $319 \mathrm{~nm}\left(\varepsilon=2600 \mathrm{M}^{-1} \mathrm{~cm}^{-1}\right), 358 \mathrm{~nm}\left(\varepsilon=2400 \mathrm{M}^{-1} \mathrm{~cm}^{-1}\right)$, $650 \mathrm{~nm}\left(\varepsilon=300 \mathrm{M}^{-1} \mathrm{~cm}^{-1}\right), 840 \mathrm{~nm}\left(\varepsilon=160 \mathrm{M}^{-1} \mathrm{~cm}^{-1}\right)$.

$\left[\mathbf{C u}^{\mathrm{II}}\left(\mathbf{L}^{1} \mathbf{O H}\right)(\mathbf{C l})\right]\left(\mathbf{B F}_{4}\right)$. From $\mathbf{L}^{1} \mathbf{O H}(194 \mathrm{mg} ; 0.80 \mathrm{mmol})$, $\left[\mathrm{Cu}^{\mathrm{II}}\left(\mathrm{H}_{2} \mathrm{O}\right)_{6}\right]\left(\mathrm{BF}_{4}\right)_{2}(138 \mathrm{mg} ; 0.40 \mathrm{mmol})$ and $\mathrm{Cu}^{\mathrm{II}} \mathrm{Cl}_{2} \cdot 2 \mathrm{H}_{2} \mathrm{O}$ (68 $\mathrm{mg} ; 0.40 \mathrm{mmol})$, the product $\left[\mathrm{Cu}^{\mathrm{II}}\left(\mathbf{L}^{1} \mathbf{O H}\right)(\mathrm{Cl})\right]\left(\mathrm{BF}_{4}\right)$ (307 mg; $0.72 \mathrm{mmol}$; 90\%) was obtained as a blue powder. ESI-MS found (calculated) for $\left[\mathrm{M}-\mathrm{BF}_{4}\right]^{+} \mathrm{m} / z 341.0$ (341.0). IR (neat, $\mathrm{cm}^{-1}$ ): $3474 \mathrm{br}, 2949 \mathrm{w}, 1611 \mathrm{~m}, 1575 \mathrm{w}, 1480 \mathrm{w}, 1443 \mathrm{~m}$, $1287 \mathrm{~m}, 1060 \mathrm{vs}, 1031 \mathrm{vs}, 1005 \mathrm{~s}, 983 \mathrm{~s}, 955 \mathrm{~m}, 871 \mathrm{~m}, 798 \mathrm{~s}, 763 \mathrm{vs}$, $723 \mathrm{~m}, 655 \mathrm{~m}, 519 \mathrm{~m}, 483 \mathrm{~m}$. Elemental analysis calcd for $\left[\mathrm{Cu}^{\mathrm{II}}\left(\mathbf{L}^{1} \mathbf{O H}\right)(\mathrm{Cl})\right]\left(\mathrm{BF}_{4}\right)$ : C 39.49, H 3.99, N 9.79; found: C 39.13, $\mathrm{H}$ 3.97, $\mathrm{N}$ 9.73. UV-vis in $\mathrm{CH}_{3} \mathrm{CN}$ at $0.1 \mathrm{mM}[\mathrm{Cu}]$ concentration: $256 \mathrm{~nm}\left(\varepsilon=11300 \mathrm{M}^{-1} \mathrm{~cm}^{-1}\right), 285 \mathrm{~nm}\left(\varepsilon=3400 \mathrm{M}^{-1} \mathrm{~cm}^{-1}\right)$, $690 \mathrm{~nm}\left(\varepsilon=90 \mathrm{M}^{-1} \mathrm{~cm}^{-1}\right)$.

$\left[\mathrm{Cu}^{\mathrm{II}}\left(\mathbf{L}^{{ }^{1}} \mathbf{N H}_{2}\right)(\mathbf{C l})\right]\left(\mathbf{B F}_{4}\right) . \mathbf{L}^{1} \mathbf{N H}_{2} \quad(133 \mathrm{mg} ; \quad 0.55 \mathrm{mmol})$, $\left[\mathrm{Cu}^{\mathrm{II}}\left(\mathrm{H}_{2} \mathrm{O}\right)_{6}\right]\left(\mathrm{BF}_{4}\right)_{2}(95 \mathrm{mg} ; 0.27 \mathrm{mmol})$ and $\mathrm{Cu}^{\mathrm{II}} \mathrm{Cl}_{2} \cdot 2 \mathrm{H}_{2} \mathrm{O}$ (47 mg; $0.27 \mathrm{mmol}$ ) were dissolved in $10 \mathrm{~mL} \mathrm{CH} \mathrm{CH}_{3} \mathrm{CN}$. This solution was added drop wise to $100 \mathrm{~mL}$ diethyl ether. The powder was filtered and washed with diethyl ether yielding $\left[\mathrm{Cu}^{\mathrm{II}}\left(\mathbf{L}^{1} \mathbf{N H}_{2}\right)(\mathrm{Cl})\right]\left(\mathrm{BF}_{4}\right)(141 \mathrm{mg} ; 0.33 \mathrm{mmol} ; 60 \%)$ as a light blue powder. Crystals suitable for X-ray structure determination were obtained by slow vapor diffusion of diethyl ether into a $\mathrm{CH}_{3} \mathrm{CN}$ solution containing the complex. ESI-MS found (calculated) for $\left[\mathrm{M}-\mathrm{BF}_{4}\right]^{+} \mathrm{m} / z 340.1$ (340.1). IR (neat, $\mathrm{cm}^{-1}$ ): $3366 \mathrm{~m}, 3303 \mathrm{w}, 1605 \mathrm{~m}, 1575 \mathrm{w}, 1477 \mathrm{w}, 1447 \mathrm{~m}, 1439 \mathrm{~m}, 1265 \mathrm{w}$, 1045vs, 1021vs, 964s, 941m, 886w, 765vs, 643m, 566m, 522m, 490m. Elemental analysis calcd for $\left[\mathrm{Cu}^{\mathrm{II}}\left(\mathbf{L}^{\mathbf{1}} \mathbf{N H}_{2}\right)(\mathrm{Cl})\right]\left(\mathrm{BF}_{4}\right)$ : C 39.28, H 4.24, N 13.09; found: C 39.34, H 4.27, N 12.97. UV-vis in $\mathrm{CH}_{3} \mathrm{CN}$ at $0.1 \mathrm{mM}$ [Cu] concentration: $258 \mathrm{~nm}(\varepsilon=$ $\left.9800 \mathrm{M}^{-1} \mathrm{~cm}^{-1}\right), 293 \mathrm{~nm}\left(\varepsilon=3900 \mathrm{M}^{-1} \mathrm{~cm}^{-1}\right), 700 \mathrm{~nm}(\varepsilon=$ $\left.110 \mathrm{M}^{-1} \mathrm{~cm}^{-1}\right), 690 \mathrm{~nm}\left(\varepsilon=220 \mathrm{M}^{-1} \mathrm{~cm}^{-1}\right)$.

$\left[\mathbf{C u}^{\mathrm{II}}\left(\mathbf{P y}_{2} \mathbf{N H}\right)(\mathbf{C l})\right]\left(\mathbf{B F}_{4}\right)$. From $\mathbf{P y}_{2} \mathbf{N H}(223 \mathrm{mg} ; 1.12 \mathrm{mmol})$, $\left[\mathrm{Cu}^{\mathrm{II}}\left(\mathrm{H}_{2} \mathrm{O}\right)_{6}\right]\left(\mathrm{BF}_{4}\right)_{2}(193 \mathrm{mg} ; 0.56 \mathrm{mmol})$ and $\mathrm{Cu}^{\mathrm{II}} \mathrm{Cl}_{2} \cdot 2 \mathrm{H}_{2} \mathrm{O}$ (96 mg; $0.56 \mathrm{mmol})$, the product $\left[\mathrm{Cu}^{\mathrm{II}}\left(\mathbf{P \mathbf { y } _ { 2 }} \mathbf{N H}\right)(\mathrm{Cl})\right]\left(\mathrm{BF}_{4}\right)$ (341 mg; $0.89 \mathrm{mmol}$; 79\%) was obtained as a dark blue powder. ESI-MS found (calculated) for $\left[\mathrm{M}-\mathrm{BF}_{4}\right]^{+} \mathrm{m} / z 296.9$ (297.0). IR (neat, $\mathrm{cm}^{-1}$ ): 3466w, 3215w, 1611m, 1574w, 1483w, $1445 \mathrm{~m}, 1285 \mathrm{w}, 1051 \mathrm{vs}, 1028 \mathrm{vs}, 1001 \mathrm{vs}, 935 \mathrm{~s}, 815 \mathrm{w}, 764 \mathrm{vs}$, $727 \mathrm{~m}, 656 \mathrm{w}, 520 \mathrm{~m}, 483 \mathrm{w}$. Elemental analysis calcd for [ $\mathrm{Cu}^{\mathrm{II}}-$ $\left.\left(\mathbf{P y}_{2} \mathbf{N H}\right)(\mathrm{Cl})\right]\left(\mathrm{BF}_{4}\right) \cdot \mathrm{H}_{2} \mathrm{O}: \mathrm{C}$ 35.76, $\mathrm{H}$ 3.75, $\mathrm{N}$ 10.43; found: $\mathrm{C} 37.01, \mathrm{H} 3.85, \mathrm{~N}$ 10.68. UV-vis in $\mathrm{CH}_{3} \mathrm{CN}$ at $0.1 \mathrm{mM}[\mathrm{Cu}]$ concentration: $255 \mathrm{~nm}\left(\varepsilon=12000 \mathrm{M}^{-1} \mathrm{~cm}^{-1}\right), 293 \mathrm{~nm}(\varepsilon=$ $\left.2100 \mathrm{M}^{-1} \mathrm{~cm}^{-1}\right), 660 \mathrm{~nm}\left(\varepsilon=120 \mathrm{M}^{-1} \mathrm{~cm}^{-1}\right)$.

$\left[\mathrm{Cu}^{\mathrm{II}}\left(\mathbf{P y}_{2} \mathbf{S}\right)(\mathbf{C l})\right]\left(\mathrm{BF}_{4}\right)$. From $\mathbf{P y}_{2} \mathbf{S}(112 \mathrm{mg} ; 0.52 \mathrm{mmol})$, $\left[\mathrm{Cu}^{\mathrm{II}}\left(\mathrm{H}_{2} \mathrm{O}\right)_{6}\right]\left(\mathrm{BF}_{4}\right)_{2}(89 \mathrm{mg} ; 0.26 \mathrm{mmol})$ and $\mathrm{Cu}^{\mathrm{II}} \mathrm{Cl}_{2} \cdot 2 \mathrm{H}_{2} \mathrm{O}$ (44 mg; $0.26 \mathrm{mmol})$, the product $\left[\mathrm{Cu}^{\mathrm{II}}\left(\mathbf{P y}_{2} \mathbf{S}\right)(\mathrm{Cl})\right]\left(\mathrm{BF}_{4}\right)(159 \mathrm{mg}$; $0.40 \mathrm{mmol} ; 76 \%$ ) was obtained as a turquoise blue powder. ESI-MS found (calculated) for $\left[\mathrm{M}-\mathrm{BF}_{4}\right]^{+} \mathrm{m} / z 313.9$ (314.0); $\left[\mathrm{M}+\mathrm{CH}_{3} \mathrm{CN}-\mathrm{Cl}-\mathrm{BF}_{4}\right]^{+} \mathrm{m} / z 320.0$ (320.0). IR (neat, $\mathrm{cm}^{-1}$ ): $2929 \mathrm{w}, 1602 \mathrm{~m}, 1568 \mathrm{w}, 1474 \mathrm{~m}, 1446 \mathrm{~m}, 1406 \mathrm{~m}, 1262 \mathrm{~m}, 1106 \mathrm{~m}$, $1074 \mathrm{~s}, 1052 \mathrm{~s}, 1024 \mathrm{~s}, 997 \mathrm{vs}, 890 \mathrm{~m}, 783 \mathrm{vs}, 764 \mathrm{~m}, 717 \mathrm{~m}, 649 \mathrm{~m}$, $518 \mathrm{~m}, 475 \mathrm{~m}$. Elemental analysis calcd for $\left[\mathrm{Cu}^{\mathrm{II}}\left(\mathbf{P y}_{2} \mathbf{S}\right)(\mathrm{Cl})\right]\left(\mathrm{BF}_{4}\right)$ : C 35.84, H 3.01, N 6.97, S 7.97; found: C 34.85, H 2.89, N 6.65, $\mathrm{S}$ 8.06. UV-vis in $\mathrm{CH}_{3} \mathrm{CN}$ at $0.1 \mathrm{mM}$ [Cu] concentration: $265 \mathrm{~nm}$ $\left(\varepsilon=11600 \mathrm{M}^{-1} \mathrm{~cm}^{-1}\right), 320 \mathrm{~nm}\left(\varepsilon=1900 \mathrm{M}^{-1} \mathrm{~cm}^{-1}\right), 360 \mathrm{~nm}$ $\left(\varepsilon=2800 \mathrm{M}^{-1} \mathrm{~cm}^{-1}\right), 690 \mathrm{~nm}\left(\varepsilon=220 \mathrm{M}^{-1} \mathrm{~cm}^{-1}\right)$.

\subsection{Catalysis experiments}

To $1000 \mu \mathrm{L} \mathrm{CH}_{3} \mathrm{CN}$ in a $1 \mathrm{~cm}$ quartz cuvette was added $1000 \mu \mathrm{L}$ catalyst solution (1.2 mM mononuclear complex or $0.6 \mathrm{mM}$ dinuclear complex solutions in $25 \mathrm{~mL} \mathrm{CH} \mathrm{CH}_{3} \mathrm{CN}$; when the complex was made in situ $\mathrm{Na}_{2} \mathrm{SO}_{4}$ was added to the stock solution to remove most of the $\mathrm{H}_{2} \mathrm{O}$ present), followed by $1000 \mu \mathrm{L}$ 3,5-di-tert-butylcatechol solution (60 $\mathrm{mM}$ stock solution in $25 \mathrm{~mL} \mathrm{CH}_{3} \mathrm{CN}$ ). The solution was stirred and temperature-controlled (temperature was kept at $25^{\circ} \mathrm{C}$ ) using a Cary Single Cell Peltier Accessory from Agilent Technologies (Type SPV-1X0) and a mixture of $\mathrm{N}_{2}: \mathrm{O}_{2}(50: 50)$ was bubbled through the solution with a needle. At the start of the measurement $\mathrm{NEt}_{3}(8.36$ $\mu \mathrm{L}, 0.06 \mathrm{mmol}$ ) was added and the formation of 3,5-di-tertbutyl-o-benzoquinone was monitored by measuring the absorbance at $400 \mathrm{~nm}$ every $0.1 \mathrm{~s}$. The resulting solution contains concentrations of $0.4 \mathrm{mM}$ [Cu], $20 \mathrm{mM}$ 3,5-DTBC and $20 \mathrm{mM}$ $\mathrm{NEt}_{3}$ unless mentioned otherwise. Every reaction was carried out at least four or five times; the error of the reaction is $\leq 8 \%$. The average values are reported.

\section{Acknowledgements}

This research has been financially supported by the National Research School Combination NRSC-Catalysis, a joint activity of the graduate research schools NIOK, HRSMC, and EPL. We thank John van Dijk for ESI-MS analysis, Fons Lefeber and Karthick Sai Sankar Gupta for assistance with the NMR 
experiments, and Jos van Brussel for elemental analysis. We thank undergraduate students Mart van Meurs, Suzanne van Daal and Mickey Harvey for the synthesis of $\left[\mathrm{Cu}_{2}^{\mathrm{II}}\left(\mathbf{L}^{\mathbf{1}} \mathbf{C}_{\mathbf{6}} \mathbf{L}^{\mathbf{1}}\right)(\mathrm{Cl})_{2}\right] \mathrm{n}\left(\mathrm{BF}_{4}\right)_{2 n}$, $\left[\mathrm{Cu}^{\mathrm{II}}\left(\mathbf{L}^{\mathbf{1}} \mathbf{N H}_{2}\right)(\mathrm{Cl})\right]\left(\mathrm{BF}_{4}\right)$ and $\mathbf{P y} \mathbf{y}_{2} \mathbf{S}$.

\section{References}

1 N. D. J. Branscombe, A. J. Blake, A. MarinBecerra, W. S. Li, S. Parsons, L. RuizRamirez and M. Schroder, Chem. Commun., 1996, 2573-2574.

2 W. Rammal, C. Belle, C. Beguin, C. Duboc, C. Philouze, J.-L. Pierre, L. Le Pape, S. Bertaina, E. Saint-Aman and S. Torelli, Inorg. Chem., 2006, 45, 10355-10362.

3 R. P. Houser, J. A. Halfen, V. G. Young, N. J. Blackburn and W. B. Tolman, J. Am. Chem. Soc., 1995, 117, 10745-10746.

4 E. C. M. Ording-Wenker, M. van der Plas, M. A. Siegler, C. Fonseca Guerra and E. Bouwman, Chem. - Eur. J., 2014, 20, 16913-16921.

5 Y. Ueno, Y. Tachi and S. Itoh, J. Am. Chem. Soc., 2002, 124, 12428-12429.

6 A. Neuba, R. Haase, W. Meyer-Klaucke, U. Flörke and G. Henkel, Angew. Chem., Int. Ed., 2012, 51, 1714-1718.

7 S. Itoh, M. Nagagawa and S. Fukuzumi, J. Am. Chem. Soc., 2001, 123, 4087-4088.

8 E. C. M. Ording-Wenker, M. van der Plas, M. A. Siegler, S. Bonnet, F. M. Bickelhaupt, C. Fonseca Guerra and E. Bouwman, Inorg. Chem., 2014, 53, 8494-8504.

9 R. R. Jacobson, Z. Tyeklar, A. Farooq, K. D. Karlin, S. Liu and J. Zubieta, J. Am. Chem. Soc., 1988, 110, 3690-3692.

10 H. Hayashi, S. Fujinami, S. Nagatomo, S. Ogo, M. Suzuki, A. Uehara, Y. Watanabe and T. Kitagawa, J. Am. Chem. Soc., 2000, 122, 2124-2125.

11 J. A. Halfen, S. Mahapatra, E. C. Wilkinson, S. Kaderli, V. G. Young, L. Que, A. D. Zuberbuhler and W. B. Tolman, Science, 1996, 271, 1397-1400.

12 W. B. Tolman, Acc. Chem. Res., 1997, 30, 227-237.

13 M. T. Kieber-Emmons, J. W. Ginsbach, P. K. Wick, H. R. Lucas, M. E. Helton, B. Lucchese, M. Suzuki, A. D. Zuberbühler, K. D. Karlin and E. I. Solomon, Angew. Chem., Int. Ed., 2014, 53, 4935-4939.

14 I. A. Koval, P. Gamez, C. Belle, K. Selmeczi and J. Reedijk, Chem. Soc. Rev., 2006, 35, 814-840.

15 C. Eicken, B. Krebs and J. C. Sacchettini, Curr. Opin. Struct. Biol., 1999, 9, 677-683.

16 S. E. Allen, R. R. Walvoord, R. Padilla-Salinas and M. C. Kozlowski, Chem. Rev., 2013, 113, 6234-6458.

17 E. Monzani, L. Quinti, A. Perotti, L. Casella, M. Gullotti, L. Randaccio, S. Geremia, G. Nardin, P. Faleschini and G. Tabbi, Inorg. Chem., 1998, 37, 553-562.

18 J. Reedijk, Science, 2005, 308, 1876-1877.

19 E. C. M. Ording-Wenker, M. A. Siegler, M. Lutz and E. Bouwman, Inorg. Chem., 2013, 52, 13113-13122.
20 H. Ertuerk, A. Hofmann, R. Puchta and R. van Eldik, Dalton Trans., 2007, 2295-2301.

21 S. Turba, O. Walter, S. Schindler, L. P. Nielsen, A. Hazell, C. J. McKenzie, F. Lloret, J. Cano and M. Julve, Inorg. Chem., 2008, 47, 9612-9623.

22 S. Schindler, D. J. Szalda and C. Creutz, Inorg. Chem., 1992, 31, 2255-2264.

23 G. J. P. Britovsek, J. England and A. J. P. White, Inorg. Chem., 2005, 44, 8125-8134.

24 E. C. M. Ording-Wenker, M. A. Siegler and E. Bouwman, Inorg. Chim. Acta, 2015, 428, 193-202.

25 E. A. Ambundo, M. V. Deydier, A. J. Grall, N. Aguera-Vega, L. T. Dressel, T. H. Cooper, M. J. Heeg, L. A. Ochrymowycz and D. B. Rorabacher, Inorg. Chem., 1999, 38, 4233-4242.

26 K. Sundaravel, M. Sankaralingam, E. Suresh and M. Palaniandavar, Dalton Trans., 2011, 40, 8444-8458.

27 H. J. J. B. Martel and M. Rasmussen, Tetrahedron Lett., 1971, 12, 3843-3846.

28 R. Herges, A. Dikmans, U. Jana, F. Kohler, P. G. Jones, I. Dix, T. Fricke and B. Konig, Eur. J. Org. Chem., 2002, 3004-3014.

29 E. C. M. Tse, D. Schilter, D. L. Gray, T. B. Rauchfuss and A. A. Gewirth, Inorg. Chem., 2014, 53, 8505-8516.

30 A. W. Addison, T. N. Rao, J. Reedijk, J. Vanrijn and G. C. Verschoor, J. Chem. Soc., Dalton Trans., 1984, 13491356.

31 M. Schatz, M. Leibold, S. P. Foxon, M. Weitzer, F. W. Heinemann, F. Hampel, O. Walter and S. Schindler, Dalton Trans., 2003, 1480-1487.

32 A. Winter, A. Zabel and P. Strauch, Int. J. Mol. Sci., 2012, 13, 1612-1619.

33 E. I. Solomon, M. J. Baldwin and M. D. Lowery, Chem. Rev., 1992, 92, 521-542.

34 O. V. Kovalchukova, K. K. Palkina, S. B. Strashnova and B. E. Zaitsev, Russ. J. Coord. Chem., 2008, 34, 830-835.

35 A. M. Thomas, B.-L. Lin, E. C. Wasinger and T. D. P. Stack, J. Am. Chem. Soc., 2013, 135, 18912-18919.

36 A. C. D. Midoes, P. E. Aranha, M. P. dos Santos, E. Tozzo, S. Romera, R. H. d. A. Santos and E. R. Dockal, Polyhedron, 2008, 27, 59-64.

37 K. Selmeczi, M. Reglier, M. Giorgi and G. Speier, Coord. Chem. Rev., 2003, 245, 191-201.

38 T. Osako, Y. Ueno, Y. Tachi and S. Itoh, Inorg. Chem., 2004, 43, 6516-6518.

39 G. M. Sheldrick, Acta Crystallogr., Sect. A: Fundam. Crystallogr., 2008, 64, 112-122.

40 A. J. M. Duisenberg, R. W. W. Hooft, A. M. M. Schreurs and J. Kroon, J. Appl. Crystallogr., 2000, 33, 893-898.

41 G. M. Sheldrick, Universität Göttingen, Germany, 1999.

42 R. Herbst-Irmer and G. M. Sheldrick, Acta Crystallogr., Sect. B: Struct. Sci., 1998, 54, 443-449.

43 A. L. Spek, Acta Crystallogr., Sect. D: Biol. Crystallogr., 2009, 65, 148-155. 